UNIVERSIDADE DE SÃO PAULO

FACULDADE DE ECONOMIA, ADMINISTRAÇÃO E CONTABILIDADE DEPARTAMENTO DE ADMINISTRAÇÃO

PROGRAMA DE PÓS-GRADUAÇÃO EM ADMINISTRAÇÃO

Gustavo Magalhães de Oliveira

Desverticalização da colheita mecanizada na cafeicultura 
Prof. Dr. Marco Antonio Zago

Reitor da Universidade de São Paulo

Prof. Dr. Adalberto Américo Fischmann

Diretor da Faculdade de Economia, Administração e Contabilidade

Prof. Dr. Roberto Sbragia

Chefe do Departamento de Administração

Prof. Dr. Moacir de Mirando Oliveira Júnior Coordenador do Programa de Pós-Graduação em Administração 


\section{Desverticalização da colheita mecanizada na cafeicultura}

Dissertação apresentada ao Programa de PósGraduação em Administração do Departamento de Administração da Faculdade de Economia, Administração e Contabilidade da Universidade de São Paulo para obter o título de Mestre em Ciências.

Área de Concentração: Economia das Organizações

Orientador: Prof. Dr. Decio Zylbersztajn

\section{Versão Corrigida}

(versão original disponível na Biblioteca da Faculdade de Economia, Administração e Contabilidade)

São Paulo

2017 
Autorizo a reprodução e divulgação total ou parcial deste trabalho, por qualquer meio convencional ou eletrônico, para fins de estudo e pesquisa, desde que citada a fonte.

FICHA CATALOGRÁFICA

Elaborada pela Seção de Processamento Técnico do SBD/FEA/USP

Oliveira, Gustavo Magalhães de

Desverticalização da colheita mecanizada na cafeicultura / Gustavo

Magalhães de Oliveira. - São Paulo, 2017.

$135 \mathrm{p}$.

Dissertação (Mestrado) - Universidade de São Paulo, 2017.

Orientador: Decio Zylbersztajn.

1. Terceirização 2. Transação 3. Mecanização agrícola 4. Colheita 5. Café 6. Brasil I. Universidade de São Paulo. Faculdade de Economia, Administração e Contabilidade. II. Título.

CDD -658.4058 
Para meus futuros alunos 



\section{AGRADECIMENTOS}

Ao realizarmos as conquistas de nossas vidas percebemos a real importância das amizades construídas ao longo do caminho. Pessoas que merecem mais que meu agradecimento, mas sim, o meu reconhecimento de gratidão perpétuo.

Ao $\mathrm{CNPq}$ pelo apoio financeiro que subsidiou e possibilitou o período de estadia em São Paulo para concretização desse sonho.

À illycaffe, em figura da Universidade do Café Brasil, pelo suporte financeiro essencial para a pesquisa de campo.

À Deus pela sabedoria, coragem e força para adentrar nos mais belos caminhos que a felicidade da vida pode proporcionar.

De modo especial, agradeço a pessoa que inspirou fortemente a minha inserção na academia, motivou-me ainda durante minha graduação pelas suas fascinantes obras e que me honrou em poder ter sua orientação com tamanha paciência, atenção e deleite: a você Professor Decio Zylbersztajn, meu muito obrigado.

Com semelhante afeição e consideração, reforço os agradecimentos a querida Professora Maria Sylvia Macchione Saes ("Sylvia"). O entusiasmo de sua presença potencializou meu desejo de poder transformar positivamente a vida de estudantes, assim como você o faz. Seu amor pela ciência e a empatia da ajuda ao próximo são características transformadoras de vidas. À você, meu muito obrigado pela amizade e pelas valiosas sugestões na Qualificação e também ao longo do desenvolvimento dessa dissertação.

Ao Professor Guilherme Fowler pelos ricos comentários durante o exame de qualificação.

À minha família. Especialmente, aos meus pais, Edson e Jane, e irmão, Leandro, pelo infinito amor, ensinamentos, conselhos, e a transmissão dos valores que formaram o indivíduo que hoje sou. E aos meus avós, Jair e Nadir, pelo carinho, atenção e o compartilhamento das experiências que motivaram muitas das decisões que realizei ao longo de minha vida.

À Gizele Celante. O seu carinho me transmitiu forças nos obstáculos mais difíceis vividos durante o mestrado. Não tenho palavras para agradecer o sentimento de "Porto Seguro" que sua companhia me trouxe nessa trajetória. Obrigado por tudo!

À família de São Paulo, meus eternos amigos de república. Vocês possibilitaram o sentimento de amor e carinho familiar pelo aconchego e amizade de cada um. Muito obrigado, Esdras "Doc", Marília "Mana", Thiaguinho, Marcel Blank, Pedro "Cabeção", Victoria, Erivelton, Luciana, Edidanlo "México", Leonardo, Jocasta, Jaciara, Marcel Mariano, Thiago "Carioca", Sergião do Paraná, Arnaud. E claro, à "Neli" por me propiciar a possibilidade de construir esses sentimentos em sua república, muito obrigado.

Aos pesquisadores e amigos do PENSA. A convivência e o carinho diário foram essenciais para transpassar a solidão da investigação científica. Meu obrigado pelo apoio incondicional e pela plena alegria dos dias de trabalho, Dilma Santos, Caroline Gonçalves e Antonio Carlos Lima Nogueira (meu muito obrigado aos dois, pelas leituras e valiosas discussões ao longo do trabalho), Fernanda Lemos, Carolina Graça, Thiago Goes, Tobias Parente, Pedro Karam, Camila Cristina, Arlete Nese e Eduardo Brunaldi ("Edu”), Kassia e Bruna. Ao Professor Claudio Pinheiro Machado Filho, Professor Samuel Giordano e Christiane Leles pelo apoio e oportunidades fornecidas.

Agradeço também aos amigos do CORS, Neca, Eder Januario, Caroline Foscaches, Paula Schnaider, Yasser Saleh, Matheus Albergaria, Lucas, Anders, Luc Wüst.

À Professora Silvia Caleman. Minha primeira orientadora. Uma mentora com conhecimento e coração de causar inveja até na comparação com as maiores obras filosóficas 
antigas. Obrigado por todo aprendizado e oportunidades. Minha admiração eterna para essa grande pessoa e profissional que tu és.

Ao Professor Milton Mariani e Dyego Oliveira pela influência nos meus primeiros anos de graduação que me motivaram a seguir a carreira acadêmica.

Aos amigos da faculdade, Fabiano Bataglia, Rafael Delmondes e Maria Eduarda "Duda" pelas palavras de alegria, diversão, carinho e atenção prestada mesmo com a distância.

Aos amigos do colégio por partilharem das alegrias e pela sincera amizade desde a "época da escola", Luiz Vinissius, Gabriel Almeida, Eric "Drops", Heitor Castro, Gabriel Rebouças "Biel", Edy Carlos, Leonardo "Boto", Adrisson Matheus "Cabeça" e Marcos André. As amigas Khariny e Larissa Neves, que retomei contato durante o mestrado e fizeram os momentos de distração prazerosos com o bom humor de ambas.

Aos participantes da pesquisa. Sem o apoio de vocês esse estudo não teria se concretizado. A bondade de ajuda ao próximo me motivou e me motivará a viver como um ser humano melhor. Em especial um muito obrigado: aos respondentes, ao Sérgio Parreiras na figura do IAC ("Sergião" você é o cara, muito obrigado!), ao Dr. Aldir Teixeira pela Experimental Agrícola do Brasil, aos membros do Clube illy, ao Ricardo Lima pela COCAPEC (obrigado por todo apoio durante minha pesquisa, sempre me lembrarei de sua bondade), Juliano Tarabal pela FUNDACCER, Amara e Sérgio D'alessandro e todos os membros do Conselho das Entidades do Café das Matas de Minas, ao Sr. Adolfo da BSCA, ao Maurício Ribeiro do Valle pela Cooxupé, , aos cooperados ou associados da COOCAFE, COCATREL, AMSC, ACARPA, SCAMG, AMOCA, e todos outros agentes do setor que contribuíram para a construção da dissertação. 


\section{RESUMO}

Oliveira, G. M. (2017). Desverticalização da colheita mecanizada na cafeicultura (Dissertação de Mestrado). Faculdade de Economia, Administração e Contabilidade, Universidade de São Paulo, São Paulo.

O Sistema Agroindustrial do Café passou por mudanças significativas em sua organização e nas estratégias adotadas pelos agentes produtivos. As transformações desencadearam a possibilidade de subcontratação de firmas especializadas em prestação de serviços de mecanização agrícola da colheita e, consequentemente, o desempenho econômico e as formas de coordenação do cafeicultor se modificaram. O objetivo da presente dissertação é identificar os determinantes da escolha de subcontratar os serviços na transação de colheita mecanizada do Sistema Agroindustrial do Café no Brasil. A investigação é construída com base em uma abordagem quantitativa com uma survey analisada por uma regressão probit, além de ser complementada com uma abordagem qualitativa. Os resultados encontrados apontaram que o sistema produtivo possui setores com diferentes graus de concentração, padrões tecnológicos, formações de preços e mecanismos de coordenação distintos ao longo da cadeia, assim como levantaram a existência de conflitos na transação de colheita mecanizada a partir do ambiente institucional e organizacional. Na sequência, o modelo econométrico validou a hipótese da especificidade de ativo e incerteza do argumento de alinhamento eficiente da teoria da Economia de Custos de Transação, além de validar o aspecto de path dependence e apontar os determinantes da subcontratação como sendo o nível de escolaridade elevado do cafeicultor e a adoção de contratos como forma de coordenação de outras transações.

Palavras-chave: terceirização, transação, mecanização agrícola, colheita, café, Brasil. 


\begin{abstract}
Oliveira, G. M. (2017). Outsourcing contracts in mechanized harvesting of coffee crop. (Dissertação de Mestrado). Faculdade de Economia, Administração, Contabilidade e Ciências Atuárias, Universidade de São Paulo, São Paulo.

The Agribusiness system of coffee has been changing its organization and strategies along the chain. The changes have risen opportunities to outsourcing harvest mechanization services with specialized firms and, consequently, economic performance and coordination mechanism in coffee grower's transactions have modified. The investigation aims to analyze the determinants of the choice of outsourcing the services of harvest mechanization transaction of the Agribusiness system of coffee in Brazil. The study is based on a quantitative approach with a survey being performed with a probit regression, and also, a qualitative approach to explore the whole scenario of the phenomenon. The results indicate that the coffee chain has different levels of market concentration, technological patterns, price formation, and different coordination mechanisms along the chain, as well as have showed the existence of conflicts between the institutional and organizational environment of the harvest mechanization transaction. The findings of the econometric model have validated the path dependence aspect and the hypothesis of the asset specificity and uncertainty of the efficient alignment argument of the Transaction Cost Economics. The model has pointed out the level of schooling and the adoption of contracts as a way of coordinating other transactions as determinants of outsourcing of harvest mechanization transaction.
\end{abstract}

Keywords: outsourcing, transaction, agricultural mechanization, harvest, coffee, Brazil. 


\section{LISTA DE QUADROS}

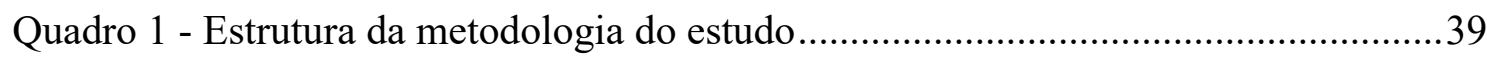

Quadro 2 - Hipóteses teóricas a partir da Economia de Custos de Transação. ................41

Quadro 3 - Síntese das variáveis da regressão probit de subcontratação de colheita

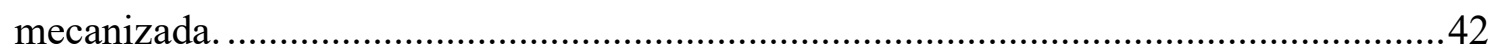

Quadro 4 - Características predominantes das Regiões Produtoras de Café no Brasil ...58

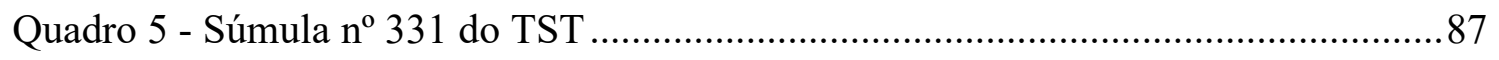

Quadro 6 - Pontos impactantes do Projeto de Lei 4330/2004 ....................................... 88

Quadro 7 - Resumo descritivo dos resultados .............................................................. 107 


\section{LISTA DE TABELAS}

Tabela 1 - Parque produtivo do café no Brasil (2012-2016) ..........................................55

Tabela 2 - Produção de Café no Brasil em 2016 ..............................................................56

Tabela 3 - Comparativo do consumo do café no Brasil (1993 e 2015) ...........................64

Tabela 4 - Receita e volume das exportações de café (2012-2016) ................................65

Tabela 5 - Resumo dos principais destinos de exportações de café (2015) ....................65

Tabela 6 - Cenário da indústria de maquinários agrícolas (1993-2014) no Brasil..........81

Tabela 7 - Perfil da propriedade e dos cafeicultores ...................................................... 96

Tabela 8 - Características da mecanização da colheita .................................................... 98

Tabela 9 - Prestadoras de serviço, relação contratual e tecnologia. .................................100

Tabela 10 - Estatística descritiva das variáveis do modelo ............................................. 102

Tabela 11 - Modelos incrementais da regressão probit com erros robustos ...................103 


\section{LISTA DE ILUSTRAÇÕES}

Figura 1 - Modelo do Sistema Agroindustrial (SAG) ....................................................22

Figura 2 - Indutores na escolha das formas de governança...........................................23

Figura 3 - Sistema Agroindustrial de Café no Brasil ..................................................50 



\section{SUMÁRIO}

1. INTRODUÇÃ

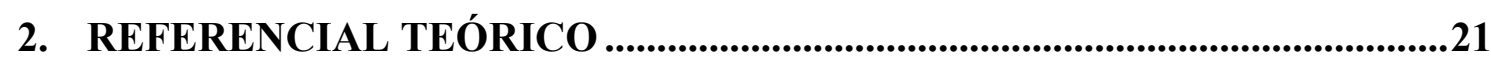

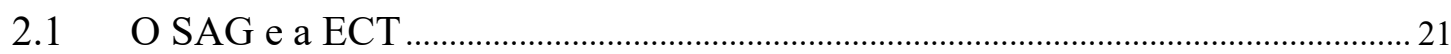

2.2 Fatores que influenciam a decisão de comprar ou contratar .................................... 25

2.2.1. Subcontratação da colheita mecanizada no mundo ............................................... 26

2.2.2. Os contratos externos de mecanização da colheita no Brasil .............................. 30

2.2.3. Subcontratação de maquinários pela ótica da ECT …………………………........ 33

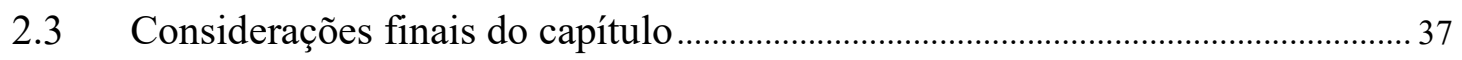

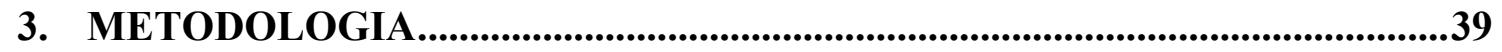

3.1 Métricas na decisão de subcontratação...................................................................... 41

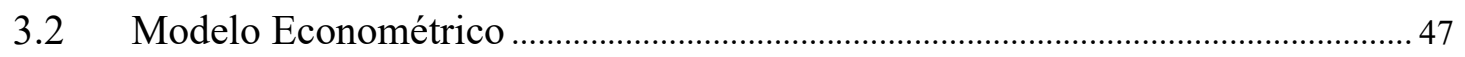

3.3 Considerações finais da metodologia .......................................................................... 48

4. REVISITANDO O SISTEMA AGROINDUSTRIAL (SAG) DO CAFÉ ..........49

4.1 Sistema Agroindustrial do Café no Brasil .................................................................. 49

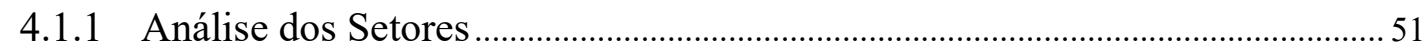

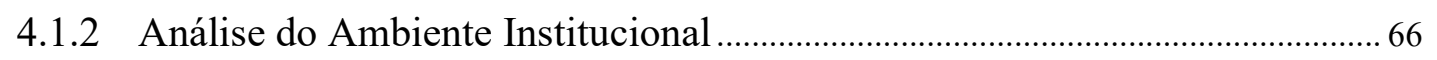

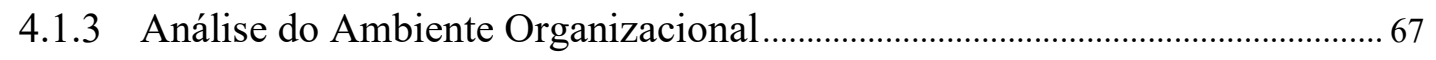

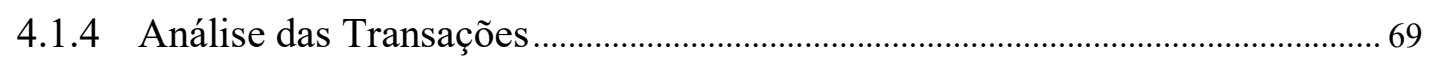

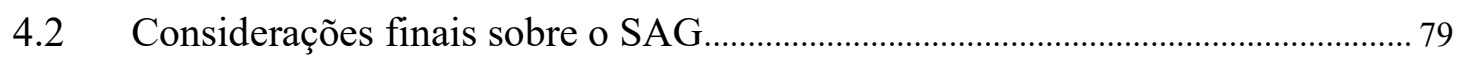

5. INDÚSTRIA DE MÁQUINAS E O CAFEICULTOR.....................................81

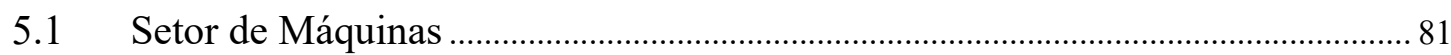

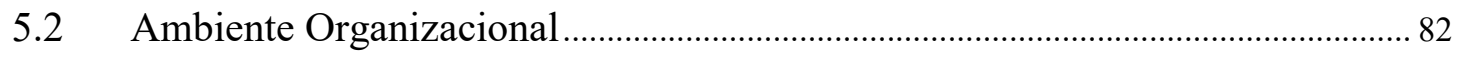

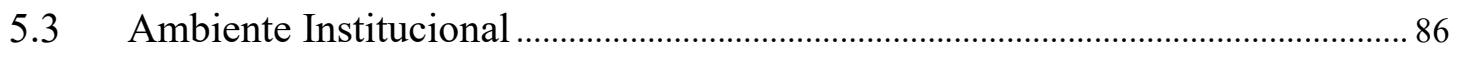

5.4 Transação de colheita mecanizada............................................................................... 92

5.5 Considerações finais sobre a transação do cafeicultor e a indústria de máquinas... 93

6. RESULTADOS QUANTITATIVOS ..............................................................95

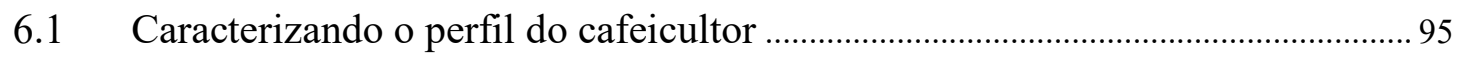

6.1.1 O perfil do produtor e da propriedade ……………………................................... 96

6.1.2 Especificações da atividade de mecanização da colheita..................................... 98

6.1.3 Características das prestadoras de serviço: ambiente contratual e tecnológico. 99

6.1.4 Considerações sobre as estatísticas descritivas. 101

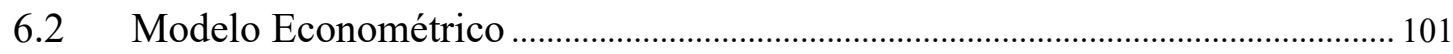

6.2.1 Considerações sobre a análise econométrica............................................................. 107

7. CONSIDERAÇÕES FINAIS.........................................................................109 
REFERÊNCIAS BIBLIOGRÁFICAS

.113

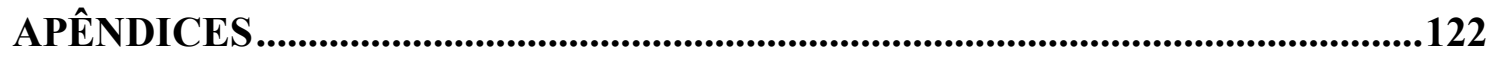

APÊNDICE 1 - Instrumento de coleta de dados........................................................122

APÊNDICE 2 - Descrição das variáveis da pesquisa ...............................................129

APÊNDICE 3 - Saídas do modelo econométrico pelo stata .......................................130 


\section{INTRODUÇÃ̃O ${ }^{1}$}

O Sistema Agroindustrial do Café passou por mudanças significativas em sua organização e nas estratégias adotadas pelos agentes produtivos. Uma evidência é a subcontratação ${ }^{2}$ de serviços de mecanização da colheita em diferentes locais e atividades (Yang, Huang, Zhang, \& Reardon, 2013; Houssou, Diao, Cossar, Kolavalli, \& Jimah, Aboagye, 2013). No Brasil o mesmo fenômeno ocorre no Sistema Agroindustrial (SAG) de Café. Observa-se que alguns cafeicultores brasileiros passaram a substituir maquinários próprios - colheitadeiras e tratores - pela prestação de serviços de firmas especializadas. Trata-se da questão colocada por Coase (1937), que ficou conhecida como a decisão entre fazer ou comprar, que influencia a necessidade de investimentos em máquinas próprias e possibilita a atualização tecnológica com impactos diretos no desempenho econômico do produtor. Exposto esse cenário, surge a seguinte pergunta de pesquisa: quais os determinantes na subcontratação de colheita mecanizada no Sistema Agroindustrial de

\section{Café no Brasil?}

Poucos estudos sobre contratação de serviços especializados na agricultura estão disponíveis, o que sugere a necessidade de melhor estudar as transações entre os agentes dos diferentes sistemas de produção, o que resultou na escolha pelo Sistema Agroindustrial de Café no Brasil.

A opção pela cafeicultura como tema de investigação é devida à relevância econômica da atividade no Brasil. O país é tido como líder mundial na produção e exportação do grão. A produção brasileira é responsável por cerca de 50 milhões de sacas de café anuais, o que representa uma diferença de 20 milhões de sacas do segundo maior produtor, o Vietnã, com 29 milhões. Ainda, a liderança produtiva caminha em conjunto com a importância econômica das exportações, com uma receita média de $\mathrm{R}$ \$ 5,3 bilhões (Ministério da Agricultura, Pecuária e Abastecimento [MAPA], 2016a).

A relevância de analisar a transação de colheita mecanizada no café se dá por dois argumentos. Primeiramente, há o surgimento do novo arranjo institucional que direciona atenção ao paradigma do make or buy da firma agrícola moderna, o qual expõe a limitação da economia de escala como único determinante na decisão dessa transação. Portanto, o objeto

\footnotetext{
${ }^{1}$ A presente dissertação contou com o apoio da Universidade do Café Brasil em parceria com a illycaffè. O autor agradece o suporte de ambas as organizações.

2 A pesquisa aborda a subcontratação pelos conceitos análogos que a literatura estabelece: terceirização, contratação externa e desverticalização.
} 
estudado encaixa-se no arcabouço teórico da Economia de Custos de Transação (ECT). O estudo contribui com a literatura que trata de subcontratação de máquinas agrícolas - que é limitada (Allen \& Lueck, 2002) - ao associá-la à hipótese do alinhamento eficiente proposta por Williamson (1985).

E segundo, dispõe-se do recorte na transação da mecanização da colheita devido ao nível da importância desse processo produtivo na qualidade final do grão (Silva, Salvador \& Padua, 2000). O crescimento da colheita mecanizada da lavoura cafeeira é um fato inquestionável e levanta as consequências na qualidade do café colhido mecanicamente por terceiros ou pelo próprio cafeicultor. Ainda, essa interferência na especificidade do café acontece em um cenário com diferentes obstáculos, desde a capacidade de imobilização de capital para uso da tecnologia e do serviço próprio a existência de prestação de serviços especializados na região da propriedade.

Diversos produtores rurais brasileiros passaram a adotar a mecanização, seja pela subcontratação de serviços ou pelo uso de maquinários próprios. De acordo com o Instituto Brasileiro de Geografia e Estatística (IBGE, 2006), cerca de 485 mil estabelecimentos rurais utilizam a prestação de serviços de mecanização agrícola em sua lavoura, o que representa $27,1 \%$ de todos os agentes que utilizam a mecanização de alguma forma.

Em contraponto, observa-se o uso de mecanização via aquisição dos equipamentos em aproximadamente 1,5 milhão de propriedades rurais, ou seja, em 52,3\% do total das propriedades $^{3}$.

A modernização da agricultura brasileira trouxe alterações nos arranjos institucionais ${ }^{4}$ na cadeia produtiva do café (Zylbersztajn, Farina \& Santos, 1993; Martins, 1999; Saes \& Farina, 1999). O relacionamento entre os agentes que atuam nos sistemas agroindustriais sofreu adaptações ao longo do tempo, que interferem na escolha do mecanismo de governança que rege a transação entre o cafeicultor e a indústria de máquinas.

A transação com a indústria de máquinas e o produtor agrícola de café passou a ser realizada por meio da contratação externa (Ministério Público do Trabalho [MPT], 2005), assim como nas culturas da soja e cana-de-açúcar (Mascarin, 2014). A adoção dessa estratégia excluiu a necessidade de investimentos para acessar as tecnologias capazes de influenciar o desempenho econômico da produção agrícola, as quais passaram a ser utilizadas pela

\footnotetext{
${ }^{3}$ A metodologia de IBGE (2006) considera apenas a propriedade rural, ou seja, o estudo não considera a concentração dos estabelecimentos rurais em um mesmo produtor.

${ }^{4} \mathrm{O}$ conceito de arranjo institucional caracteriza uma forma de coordenação de determinada transação e suas atividades produtivas (Davis \& North, 1971; Williamson, 1975; Coase, 1991). Ao longo do trabalho são adotados os termos "arranjo institucional", "forma e/ou estrutura de governança" e "mecanismo de coordenação" como sinônimos.
} 
subcontratação de serviços, e não somente pela aquisição dos maquinários próprios. Contudo, os fatores que afetam a escolha dos produtores são pouco conhecidos e torna-se importante o levantamento de possíveis determinantes para a aquisição ou terceirização dos serviços de colheita mecanizada.

Desta maneira, a presente pesquisa objetiva estudar os determinantes da escolha de subcontratar os serviços de equipamentos, total ou parcialmente, na transação de colheita mecanizada do Sistema Agroindustrial do Café no Brasil. Os objetivos específicos do presente estudo são: i) revisar as características ${ }^{5}$ das transações do SAG do café no Brasil; ii) analisar os ambientes institucional e organizacional que permeiam as transações entre o cafeicultor e a indústria de máquinas; iii) apresentar os determinantes na decisão de integrar verticalmente ou subcontratar a mecanização da colheita do cafeicultor brasileiro.

A presente dissertação está estruturada em sete capítulos. O capítulo 2 expõe o referencial teórico da ECT e revela os determinantes de subcontratação da mecanização da colheita agrícola apresentados na literatura. O capítulo 3 apresenta o método utilizado em cada capítulo, detalha o modelo econométrico probit multivariado e as métricas utilizadas. $\mathrm{O}$ capítulo 4 apresenta a recaracterização das relações do SAG do café com base na ECT. O capítulo 5 aprofunda a análise da transação entre o cafeicultor e a indústria de máquinas com base em seus ambientes institucional e organizacional. O capítulo 6 expõe os resultados explicativos da decisão de verticalizar ou subcontratar a colheita mecanizada. $\mathrm{O}$ capítulo 7 exibe as considerações finais e as limitações da pesquisa.

\footnotetext{
${ }^{5}$ Este objetivo compara as transações atuais do Sistema Agroindustrial do Café com os estudos anteriores de Zylbersztajn et al. (1993) e Saes e Farina (1999), isto é, atualiza as informações acerca do setor.
} 


\section{REFERENCIAL TEÓRICO}

O presente capítulo expõe a formação do conceito de Sistema Agroindustrial, o arcabouço teórico da Economia de Custos de Transação e os determinantes da subcontratação de colheita mecanizada à luz de três cenários: agricultura mundial, agricultura brasileira e um retrato embasado na ECT.

\subsection{O SAG e a ECT}

O conceito de SAG foi tratado por Zylbersztajn (1996), a partir da sua origem nos anos 50. O método de análise nele embasado ficou conhecido como Commodity System Approach (CSA). Davis e Goldberg (1957) definem que:

\footnotetext{
Um sistema de "commodities" engloba todos os participantes envolvidos na produção, processamento e comercialização de um produto. Esse sistema inclui o mercado de fornecimentos agrícolas, produção agrícola, operações de armazenamento, processamento, atacado e varejo, delimitando um fluxo que varia de insumos para o consumidor final. $O$ conceito engloba todas as instituições que afetam a coordenação das etapas sucessivas de um fluxo de mercadorias, como o governo, os mercados de futuros e as associações comerciais. (p. 2, traduzido).
}

Para Davis e Goldberg (1957) o surgimento do agribusiness - conceito-chave do CSA - deu-se no início do século XIX, quando os produtores rurais deixaram de apenas plantar e colher suas lavouras ou criar seus animais e começaram a fabricar suas próprias ferramentas de produção, como os fertilizantes, equipamentos de processamento e de beneficiamento.

O termo "agronegócio" foi fruto da quebra de isolamento analítico da agricultura, que predominava até então. A análise agrícola passou a ser construída com outras lentes analíticas. Em trabalho posterior, Zylbersztajn (1996) associou o conceito ao trabalho de Coase (1937), que definiu a firma como um nexo de contratos. Zylbersztajn (1996) sugeriu que o SAG pode ser visto como uma firma coasiana expandida. A mudança das lentes de análise possibilitou outras interpretações acerca da verticalização das transações à jusante ou à montante das indústrias de insumos, beneficiamento e/ou comercialização. $O$ novo embasamento trouxe à tona a possibilidade de outros tipos de estudos sobre as diferentes estruturas organizacionais com poder de decisão, funções e operações próprias (Davis \& Goldberg, 1957; Goldberg, 1968).

Parte da introdução do agronegócio na literatura de estratégia ocorreu por meio de Zylbersztajn (1996). Após essa inserção, diversas pesquisas passaram a contribuir para o melhor entendimento desse aporte teórico dentro da realidade brasileira (Miele \& 
Zylbersztajn, 2005; Mizumoto \& Zylbersztajn, 2006; Caleman \& Zylbersztajn, 2012; Oliveira, Caleman, Cunha, \& Zylbersztajn. 2014) e do cenário internacional (Lajili, Barry, Sonka \& Mahoney, 1997; Cook \& Chaddad, 2000; Reardon \& Barrett, 2000; Hendrkse \& Veerman, 2001; Lazzarini, Chaddad \& Cook, 2001).

As investigações científicas que usufruíam de um objeto de estudo do agronegócio usualmente eram associadas às temáticas da Economia das Organizações. Zylbersztajn (1995) ressalta que o principal motivo da estrutura de organização de um Sistema Agrondustrial (SAG) (Figura 1) é a visão dos limites da firma de Coase (1937), além das contribuições de Williamson $(1975,1985,1996)$ com a formação da Economia de Custos de Transação (ECT). Portanto, pode-se dizer que a formação metodológica do SAG sofreu influência de três disciplinas inter-relacionadas: economia das organizações, estratégia e agribusiness - CSA.

Figura 1 - Modelo do Sistema Agroindustrial (SAG)

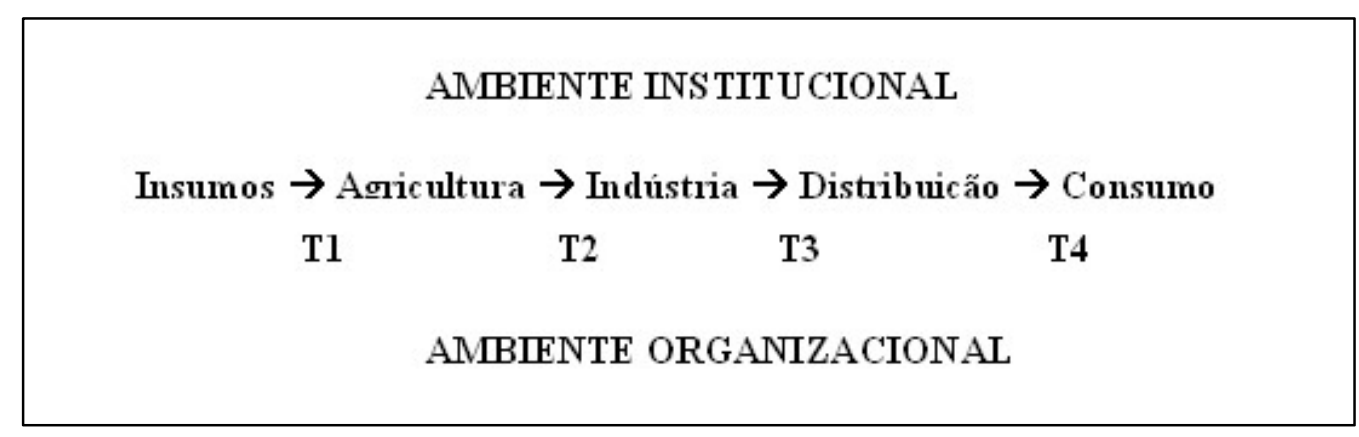

Fonte: Zylbersztajn (1995).

Neves e Caleman (2015) afirmam que ao utilizar o modelo de análise de SAG do PENSA são necessários procedimentos para resultados investigativos eficientes. A primeira etapa exige a descrição e caracterização dos setores de cada uma das indústrias envolvidas na cadeia. Posteriormente, parte-se para a observação macroanalítica dos ambientes institucional e organizacional, assim como, a investigação microanalítica quanto às transações entre os agentes (mecanismo de coordenação, sistemas de incentivo/monitoramento, definição das características da transação).

De acordo com os autores, o modelo analisa um produto com base nos seguintes recortes:
1. Setores
2. Ambiente organizacional
3. Ambiente institucional
4. Transações 
A análise investiga a estrutura dos setores produtivos (insumos, produção primária, beneficiamento, distribuição e consumo) como, por exemplo, concentração de mercado, empresas líderes e tecnologias, assim como as interações com o ambiente institucional e o ambiente organizacional e nas transações dentre os diversos relacionamentos.

O construto tem o enfoque da ECT, que foi iniciado e consolidado por Williamson (1975; 1985). O autor apresenta um modelo para a análise da eficiência da governança das firmas com base nas características da transação (especificidade de ativos, frequência e incerteza), dos pressupostos comportamentais (oportunismo e da racionalidade limitada), além do ambiente institucional e organizacional.

Figura 2 - Indutores na escolha das formas de governança

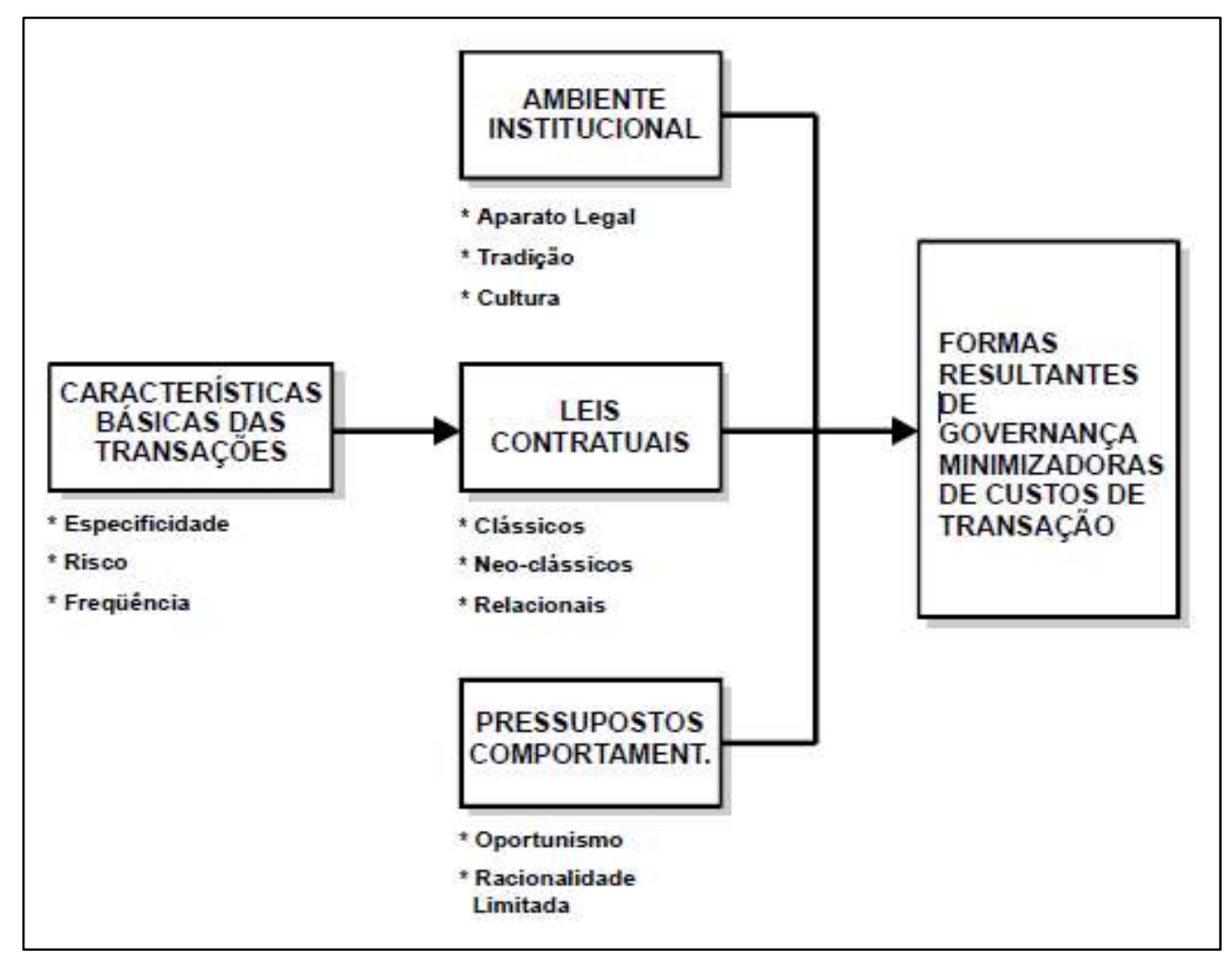

Fonte: Zylbersztajn (1995).

Na teoria da ECT, a especificidade de ativos (k), a incerteza (U) e a frequência (R) associadas ao ambiente institucional definem os mecanismos eficientes de governança, que variam de mercado a integração vertical, sendo a especificidade de ativos a principal variável, a “jugular”, segundo Williamson (1983, 1991).

A especificidade de ativos é vista como investimentos específicos para uma transação em particular que perdem valor com o seu uso em relacionamentos alternativos (Williamson, 1981). Há três níveis de especificidades diferentes: $\mathrm{k}=0$, quando os ativos são totalmente reutilizáveis; $\mathrm{k}=\mathrm{m}$, quando há um nível supostamente intermediário de 


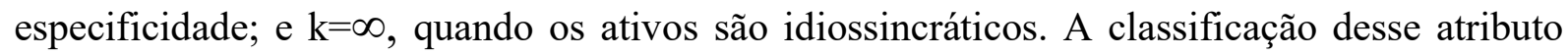
ocorre de acordo com a natureza envolvida, tal como: i) locacional; ii) física; iii) humana; iv) ativos dedicados; v) marca; vi) temporal.

A frequência é medida pela recorrência das negociações (Zylbersztajn, 1996; Farina, 1999). O foco nessa característica é acentuado pelos pressupostos comportamentais, como no caso do surgimento de mecanismos reputacionais a partir de uma maior frequência das transações.

Os pressupostos comportamentais que fazem parte da teoria são a racionalidade limitada e o oportunismo. O primeiro é a incapacidade cognitiva para o processamento completo de todas as informações (Simon, 1955). O segundo é o autointeresse buscado com avidez (Williamson, 1985, 1996).

A incerteza surge como a incapacidade de previsão de eventos (Williamson, 1985, 1996; Farina, 1999). Esse atributo é diretamente associado aos ambientes institucional e organizacional, os quais auxiliam a coordenação e organização das transações nos sistemas agroindustriais (Zylbersztajn, 1996). Ainda, essa característica pode assumir três perspectivas distintas: a incerteza de mercado, tecnológica e institucional (Williamson, 1985; North, 1991; Lajili, Madunic, \& Mahoney, 2007).

O ambiente institucional é formado por instituições que podem reduzir custos de transação e incerteza, além de potencializar o desempenho econômico das transações envolvidas (North, 1991). As instituições podem ter papel político ou econômico, caráter formal (legislações, normais e decretos) ou informal (costumes, cultura, tradições).

$\mathrm{Na}$ estruturação da abordagem adotada neste estudo, o ambiente organizacional ganha relevância. O ambiente é representado pelas organizações de apoio ao funcionamento dos SAGs. A natureza dessas entidades pode ser política (partidos políticos), de crédito (instituições financeiras), educacionais e de pesquisa (universidades, institutos tecnológicos, laboratórios), econômica (câmaras setoriais, sindicatos, associações, cooperativas, organizações não governamentais) (North, 1991).

Conforme apresentado por Zylbersztajn (1996, 2000, 2013), as análises sobre Sistemas Agroindustriais podem ser pautadas nas características das transações, nos ambientes institucional e organizacional e nos custos de transação. A análise das estratégias no SAG pode ser embasada na ECT como forma de tornar as decisões dos agentes econômicos do setor mais precisas, especificamente, na adoção dos arranjos institucionais 
(hierarquia, híbrido e mercado). Essa lacuna carrega a necessidade da análise com enfoque nos custos das transações como um importante driver a ser considerado (Coase, 1937, 1998).

\subsection{Fatores que influenciam a decisão de comprar ou contratar}

A presente subseção apresentará a literatura sobre mecanização agrícola da colheita de modo geral. Ainda nesta seção, é exposta a ótica de subcontratação com base no campo de estudos da Economia das Organizações. Posteriormente, na próxima subseção descrevem-se os estudos que tratam da subcontratação de mecanização agrícola da colheita no mundo. $\mathrm{Na}$ sequência, expõe-se a mesma literatura, mas agora direcionado para casos brasileiros. Por último, surge a apresentação conjunta da subcontratação no cenário da cafeicultura brasileira sob as lentes da Economia de Custos de Transação.

O tema da terceirização é tratado à luz da Economia das Organizações. Coase (1937) inaugura a análise da terceirização sob o prisma da economia organizacional. Entre outras contribuições, o autor estudou os determinantes das fronteiras das firmas visando à eficiência econômica a partir da desverticalização das transações. A tomada de decisão diante desses dois polos - mercado/subcontratação/buy e hierarquia/integração vertical/make - visa à captura dos benefícios econômicos disponíveis para a realidade individual de cada firma, tais como os ganhos de economia de escala e/ou a minimização dos custos de transação.

Williamson $(1985$; 1996) explica que o tamanho da firma é definido por critérios de eficiência econômica na desburocratização dos relacionamentos internos. A desverticalização depende dos custos de transação envolvidos na decisão do "make or buy" (Williamson, 2005).

A contratação externa em análise baseia-se na perspectiva dos custos de transação e no aspecto de especialização. A decisão explora os benefícios intrínsecos à particularidade de cada transação. Por um lado, a terceirização pode ser acompanhada da desnecessidade de imobilização de capital, flexibilidade de tempo do produtor para realização de outras atividades, e da qualificação do serviço subcontratado. Por outro lado, a aquisição do maquinário próprio pode trazer vantagens para o produtor, entre as quais: protegê-lo de potenciais conflitos com o prestador de serviço, poupá-lo de problemas judiciais, prevenir as adversidades do atraso na realização da atividade, e resguardá-lo de contratempos no transporte dos equipamentos até a propriedade rural.

Os agentes dos sistemas produtivos agrícolas podem sofrer interferências distintas em tal decisão dualística. Diante disso, faz-se necessário analisar os aspectos relevantes na 
mecanização da colheita em diferentes cenários, objetivando levantar as possíveis influências no processo decisório do cafeicultor brasileiro.

\subsubsection{Subcontratação da colheita mecanizada no mundo}

A literatura que trata sobre a subcontratação de atividades na produção agrícola ainda se encontra em fase de desenvolvimento, especialmente sobre o processo de colheita mecanizada. Portanto, o contraponto entre o uso de máquinas e mão de obra humana é apresentado anteriormente à argumentação da contratação externa no meio rural.

A relevância do procedimento de tornar a atividade agrícola mecanizada é embasada pela magnitude de custo intrínseco no fator produtivo "trabalho" (Calvin \& Martin, 2012). Ainda de acordo com os autores, a despesa com mão de obra possui representatividade na estrutura de custo em uma propriedade rural, que pode chegar a $42 \%$, como no caso da colheita de frutas e vegetais produzidos nos Estados Unidos. Os pesquisadores utilizam a abordagem dos preços relativos ao ressaltarem o uso das colheitadeiras como forma de minimização dos custos na contratação de mão de obra.

Além do prisma de dispêndio de recursos, observa-se a eficiência produtiva como uma variável influente no que tange à mecanização agrícola. Takeshima, Nin-Pratt \& Diao (2013) afirmam que a colheita mecanizada é crucial em situações onde os altos custos com a mão de obra afetam negativamente a produtividade do agricultor.

A substituição do trabalho manual pelas máquinas, contudo não é um cenário simplista e linear. A viabilização do uso de tecnologias na colheita é uma decisão complexa e com direcionamento multifocal. A literatura internacional apresenta alguns fatores limitadores na decisão de internalizar esses recursos, como o tamanho da propriedade, por exemplo (Igata, Hendriksen \& Heijamn, 2008; Otsuka, 2012; Tiepo, 2015) ou a falta de crédito de subsídios governamentais (Hossou et al., 2013).

A fim de contornar tais obstáculos e tornar a produção agrícola mais eficiente, os agentes econômicos passaram a adotar a prestação de serviço especializada de mecanização da colheita. A prestação de serviços com este enfoque vem ganhando força nos sistemas produtivos agrícolas modernos. O uso da desverticalização dessa transação está ocorrendo tanto em países desenvolvidos (Igata, Hendriksen \& Heijamn, 2008; Fisher \& Knutson, 2012; Takeshima, Nin-Pratt \& Diao, 2013; Guo et al., 2015) quanto naqueles em desenvolvimento (Hossou et al. 2013; Yang et al., 2013; Chaddad, 2014; Tiepo, 2015).

Como primeiro caso dos países subdesenvolvidos, Yang et al. (2013) afirma que o processo de mecanização da colheita - seja pela aquisição ou pelo uso de subcontratação de 
serviços - passou a se destacar por meio de um processo de desenvolvimento de técnicas produtivas desde 2004, na China. O país passou a ter carência de mão de obra rural produtiva em resposta ao progresso industrial anos 70 e 80 . O movimento de migração urbano acarretou a dificuldade de emprego de mão de obra, principalmente a especializada.

No ano de 2009, já era notável uma presença seis vezes mais representativas das máquinas nos processos de colheita chinesa. A abertura do mercado de provedores especializados nesta subcontratação apareceu como consequência da dificuldade com investimentos em ativos imobilizados, e o aumento do salário do trabalhador.

O estudo mencionado descreve alguns desafios a serem contornados pela nova forma de coordenação do uso de mecanização agrícola. Os contratantes passaram a se preocupar com fatores que pudessem incentivar ou não a terceirização. Alguns pontos chamaram atenção na investigação. O tamanho da propriedade foi uma característica capaz de potencializar o uso de máquinas próprias, porém a adoção dos contratos externos com firmas especializadas sofreu desmotivação pela estrutura de máquinas presente na propriedade, ambos em razão da escala. A distância entre o contratado e o contratante surgiu como um mecanismo capaz de desincentivar o relacionamento, pois o transporte das máquinas entre as províncias chinesas acarretava uma despesa proporcional ao distanciamento entre os agentes, e ainda, possibilitava a ocorrência de danos nos maquinários durante o deslocamento.

Hossou et al. (2013) apresenta o caso do avanço da terceirização desse serviço em Gana. O processo de mecanização da colheita recebeu suporte do governo ganês a partir de 2007, pois o Estado iniciou a criação de subsídios para estabelecimento de centros privados de prestação de serviços locais. A iniciativa objetivou expandir o alcance da mecanização ao longo do país, pois parte dos produtores rurais não detinham a tecnologia por inacessibilidade de natureza geográfica - transporte das máquinas considerável custoso - e/ou a incapacidade de investimento. Ademais, a ação inovadora fomentou o surgimento de iniciativas privadas independentes, capazes de suprir os produtores dessa região.

Os pesquisadores enfatizam dois pontos quanto ao uso dos provedores especializados na mecanização da colheita: o tempo e a localização. $O$ aspecto temporal é caracterizado pela perenidade das culturas produzidas e a influência das chuvas. $\mathrm{O}$ uso dos maquinários ocorre principalmente nos meses de junho e julho no norte de Gana, enquanto no sul acontece de abril a junho e de setembro a outubro; logo, o planejamento referente ao tempo para a realização da atividade de colheita torna-se primordial. Quanto à característica de localização, há a dificuldade da migração de máquinas de um polo a outro como um obstáculo expressivo, já que os investimentos na terceirização podem aparecer como crescentes quanto maior for o 
distanciamento entre ambos agentes. Sendo assim, além da variável tempo para colheita como fator importante, a logística para a mecanização também influencia a relação do desempenho na escolha entre subcontratar ou adquirir os maquinários próprios,

Takeshima, Nin-Pratt \& Diao (2013) expõem a mecanização agrícola como um dos fatores essenciais do desenvolvimento do setor agrícola, assim como um mecanismo capaz de reduzir a pobreza em propriedades de famílias rurais na África subsaariana, especialmente na Nigéria.

O atributo de localização manifesta-se novamente como interferente na subcontratação, porém com complementação pela estrutura de investimentos em máquinas da propriedade (Takeshima, Nin-Pratt \& Diao, 2013). No sul nigeriano é observada a presença de agricultores que adotam a mecanização conforme sua intensidade tecnológica produtiva. Já no norte esse cenário se repete, porém a terceirização é vista como um recurso adicional para complementação de força de trabalho.

O estudo refuta, ainda, a hipótese do uso dos serviços de mecanização como universal ao apresentar a inviabilidade dos serviços para alguns produtores nigerianos. Os pesquisadores enfatizam que o preço dos subcontratados varia de acordo com a localização do agricultor contratante. Em algumas propriedades é inviável a aplicação da terceirização, pois o custo para transporte das máquinas encarece a atividade das prestadoras de serviço e, consequentemente, torna a decisão impraticável.

Ao voltar para o ambiente dos países desenvolvidos, existe a dificuldade com contratação de trabalhadores no setor de frutas e vegetais dos Estados Unidos (Calvin \& Martin, 2012). Os autores entendem que a mecanização emergiu como uma forma de contornar o obstáculo de especialização de mão de obra, como na falta de formação e de conhecimento técnico para atuação nas lavouras. Diante disso, evidencia-se que a decisão de desverticalização das máquinas é interligada com fatores tecnológicos, temporais e do perfil das propriedades contratantes.

A mecanização apareceu como diluidor de custos fixos do capital imobilizado para grandes produtores, além da escala gerada pela capacidade produtiva (Calvin \& Martin, 2012). E ainda, a importância do tempo correto para colheita se destacou novamente. O aspecto temporal é primordial, por exemplo, na cultura da alface prematura, visto que o produto analisado é de uma verdura que carrega seu valor pela imaturidade, isto é, a alface necessita ser colhida em um momento anterior ao de seu total amadurecimento.

Concomitantemente, a investigação da mecanização na agricultura norte-americana evidencia a interferência da complexidade tecnológica na subcontratação. As culturas da uva e 
da laranja são destacadas como exemplos em que se requerem transformações constantes da tecnologia. Os equipamentos de colheita para essas frutas sofrem adaptações de acordo com a realidade do produtor, ou seja, as alterações apresentadas por novos maquinários carregam imprevisibilidade de eficiência na mecanização nas particularidades dessas produções.

Ainda com enfoque nos Estados Unidos, Fisher e Knutson (2012) explicam que o cenário norte-americano possui direcionamento para uma mecanização especializada. Os autores retratam a contratação externa do serviço como exigente de treinamento e experiência na operacionalização das máquinas. Essa exigência de capacitação dos operadores é responsável por uma parte considerável na decisão de subcontratar uma prestadora de serviços especializada.

Já Igata, Hendriksen e Heijamn (2008) tratam desse enfoque na Holanda e no Japão. Os benefícios da terceirização dos serviços mecanizados para os produtores holandeses são destacados principalmente por quatro pontos: diminuição de imobilização de capital pela desnecessidade de propriedade sobre os maquinários, obtenção de serviços de alta qualidade, preços aceitáveis para contratação e liberação de tempo do produtor para outras atividades.

Os autores afirmam que as variáveis impactantes na decisão de terceirizar a mecanização são: tamanho da propriedade, escassez de mão de obra, diversificação da produção, valor do capital imobilizado em maquinários próprios e aspectos culturais. $\mathrm{O}$ tamanho é verificado pela interferência de capacidade de pequenos produtores em adquirir a tecnologia, além de mantê-la moderna. Os empregados influenciam no momento em que a disponibilidade de mão de obra familiar ou temporária está acessível a ponto dos salários serem menos custosos do que os contratos. A diversificação enfatiza a exigência de atenção em atividades variadas, pois operações simples passam a ser terceirizadas, enquanto ações complexas passam a receber maior cuidado. A propriedade das máquinas apresenta a desnecessidade de terceirização, visto que, caso o produtor já detenha a tecnologia em sua produção, não há motivação para buscar os equipamentos por meio de contratos externos. Já o fator cultural explica que enquanto a nação japonesa possui referência de trabalho manual como eficiência produtiva, no país europeu o quadro é voltado para a modernização.

Ainda no que tange o continente europeu, Navarro (2002) salienta que as modificações para desverticalizar atividades rurais ganharam força no início do século XXI nessa região. A autora evidencia que o uso de contratação externa na Espanha é quase inexistente nos casos que o produtor tem suas próprias colheitadeiras. Ainda, a estudiosa afirma que nesse país, em conjunto com a Itália e França, surge a profissionalização dos trabalhadores rurais como um ponto de preocupação do agricultor no ato de contratar. 
Ao retomar a realidade espanhola, vê-se a perspectiva da relevância da tradição da região ou da família do produtor (Navarro, 2002). O costume de realizar a externalização da colheita para agentes terceiros acarreta a sua continuidade. Ademais, a investigação levanta que tarefas específicas para regiões de montanha influenciam a escolha de subcontratar o serviço. A disponibilidade de agentes capazes de atuar em topografias acidentadas pode restringir a ação do produtor de desverticalizar a atividade da colheita mecanizada, pois o serviço passa a atingir um nível de qualidade subótimo em contraponto a uma propriedade com relevo plano.

Posto isso, observa-se que o movimento de subcontratação de atividades mecanizadas na agricultura vem sendo bem aceito pelos produtores rurais de diversos países. A adoção da prática tem sido influenciada por fatores diversos de acordo com a realidade de cada situação. Características como grau de investimento em tecnologia própria, especialização da mão de obra, localização entre o contratado e contratante, preocupação com o tempo na colheita, complexidade tecnológica, tradição na atividade e relevo da propriedade são fatores que se encontram em evidência na tomada de decisão sob este enfoque ao redor do mundo. Contudo, como essa realidade está se situando no agronegócio brasileiro?

\subsubsection{Os contratos externos de mecanização da colheita no Brasil}

A literatura que trata da subcontratação de serviços de mecanização agrícola na colheita é escassa no Brasil. Esse campo ainda apresenta espaço para pesquisas, pois, mesmo com o movimento de migração do campo para a cidade e da importância da força de trabalho na atividade da colheita (Ferreira \& Ortega, 2004), o fenômeno de revolução tecnológica na agricultura pode ser considerado recente no Brasil.

A análise da escolha entre a terceirização dessa atividade ou sua adoção interna na literatura, no Brasil, é focada principalmente em culturas extensivas, como na silvicultura e sojicultura. Canto et al. (2006) apresentam o caso de silvicultores no Estado do Espírito Santo e evidenciam que os principais fatores na indução de uso de terceiros no serviço de colheita florestal são inacessibilidade financeira na aquisição de máquinas e equipamentos, falta de conhecimento técnico do produtor para atuar de modo independente, indisponibilidade de tempo para atuar exclusivamente na atividade. Outro achado relevante do estudo é a interferência da topografia na decisão. Áreas de produções com relevo plano possuem mais contratos na prestação de serviço, pois a geografia plana potencializa os resultados da colheita mecanizada. Todavia, a investigação explica que o uso de terceiros é decorrente da falta de 
recursos do produtor para usar mecanismos internos para gerir essa etapa produtiva, isto é, há maior tendência no uso das máquinas próprias quando possível.

Morais Filho (2006) avalia o setor florestal brasileiro e apresenta os obstáculos na decisão de optar pela contratação externa do serviço de colheita nesta cadeia. O pesquisador observou a existência de casos em que a prestação de serviço foi realizada com baixa especialização na mão de obra, a ponto de conhecimentos técnicos básicos serem desconhecidos pelo prestador, assim como situações em que os maquinários eram ultrapassados tecnologicamente e carentes de manutenção, o que tornava a operação mais onerosa e menos eficiente.

Morais (2012), por sua vez, enfatiza a preocupação com o atraso nas atividades da produção de madeira, em especial na etapa da colheita, quando há a possibilidade de perdas pela demora na prestação de serviços. A autora realça que o uso da subcontratação deve surgir com planejamento e análise de viabilidade pelo produtor, e não como uma decisão sem organização e de caráter fortuito.

Novais e Romero (2009) argumentam sobre a possibilidade de ineficiência produtiva em razão de atrasos na operação. Os autores expõem que a tomada de decisão quanto à terceirização não deve ser pautada apenas em aspectos financeiros. Para eles, o uso de recursos próprios pode trazer autonomia para melhor execução das tarefas, e ainda, a disponibilidade de maquinários próprios na propriedade possui o potencial de minimizar perdas advindas de atrasos no momento de realização das atividades da colheita.

Outro ponto levantado pelos pesquisadores é interligado ao prisma de investimento. O levantamento feito pelo estudo aponta que a busca pela terceirização visa à redução de imobilização do capital. Alguns produtores não se utilizam da terceirização no caso em que detêm as tecnologias em sua lavoura, assim como em situações em que possuem um quadro de trabalhadores suficiente para a realização da atividade de colheita, visto que diluem os custos fixos de modo similar ao prestador de serviços. Esse ponto enfatiza que a complementação de força de trabalho pela subcontratação é pouco presente nesse ambiente, ou seja, a decisão surge como uma exclusiva internalização ou externalização tanto dos benefícios quanto das responsabilidades.

Zanchet (2009) salienta a decisão de verticalização para a realidade de agricultura familiar na cultura de soja. O pesquisador mostra que, de modo geral, os produtores familiares não contratam externamente essa prestação de serviço quando detêm o próprio maquinário.

De acordo com Laurenti (2004), o uso de terceiros em serviços agrícolas vem ganhando força em função da questão trabalhista no campo, com a criação do Projeto de Lei 
$\mathrm{n}^{\mathrm{o}}$ 4330/2004. O autor alega que produtores rurais brasileiros estão adotando o uso de contratos externos na colheita com o objetivo de diminuir os riscos de conflitos judiciais na esfera trabalhista. Apesar disso, a regulação trabalhista proposta no PL sofreu alteração em 2015 e passou a prever responsabilidade solidária em casos de descumprimento de normas trabalhistas. Ou seja, o agricultor passou a ser responsável pelo cumprimento dessas obrigações.

Como um caso diferenciado das culturas extensivas, Ferreira e Ortega (2004) analisam a mecanização da colheita no setor produtivo do café. A pesquisa mostra que a produção do grão em regiões montanhosas vem abrindo espaço para a introdução das tecnologias de automação na colheita, porém a viabilização desse processo é distinta dos casos em que a propriedade se encontra em um relevo plano, em que é possível potencializar os resultados alcançados pelo atual padrão tecnológico das grandes máquinas.

Diferentemente de Igata, Hendriksen e Heijamn (2008), no cenário mundial, e Canto et al. (2006), na realidade do Brasil, os autores apontam o uso de terceirização da colheita por grandes produtores. Ferreira e Ortega (2004) apresentam cafeicultores de grande porte que optam pela prestação de serviços mesmo com a capacidade de imobilizar capital em ativos próprios. $\mathrm{O}$ argumento apresentado pelo estudo enfatiza que o ambiente dessa transação não é uma simples análise de possibilidade de investimento, mesmo que essa seja importante.

Os autores indicam, ainda, outros dois exemplos do fator trabalho como influentes nessa decisão na cultura cafeeira. Para eles, o cafeicultor deve observar cuidadosamente a incorporação dos progressos técnicos alcançados pelas tecnologias relacionadas à mão de obra. A inserção dos novos equipamentos caminha em consonância com a especialização de trabalhadores capazes de operá-los de modo eficiente. A modernização das tecnologias de mecanização realça a preocupação com a capacitação dos condutores do produtor rural, bem como denota a ineficácia da tecnologia ao ser utilizada por uma mão de obra com pouca capacitação.

Expostos esses argumentos, observa-se que a situação do Brasil se assemelha em algumas características ao cenário mundial. Os aspectos timing da prestação do serviço, existência de mão de obra qualificada, entre outros fatores, também são relevantes para os produtores rurais brasileiros, porém surgiram alguns pontos inéditos, como no caso da preocupação com legislação trabalhista. Portanto, com base nas evidências dos diferentes países e culturas agrícolas, é possível observar o encaixe da vertente teórica da Economia de Custos de Transação (ECT) como uma possibilidade de análise na cadeia cafeeira do Brasil. 
Dessa forma, a próxima seção traz o encaixe de pontos relevantes na tomada de decisão de subcontratar ou internalizar a mecanização da colheita com base nessa literatura.

\subsubsection{Subcontratação de maquinários pela ótica da ECT}

A prestação de serviços de mecanização agrícola da colheita ampliou a governança pela subcontratação. A mudança possibilitou o uso dos contratos externos como uma nova forma de coordenação da transação e, consequentemente, despertou o dilema acerca das relações via contratos, como, por exemplo, a preocupação com as quebras contratuais e os problemas de hold-up já iniciada por Klein, Crawford e Alchian (1978) e Williamson (1985). A eficiência econômica na coordenação associa-se às especificidades de ativos e às outras características da transação (incerteza e path dependence), o que leva ao principal questionamento da teoria da firma - a integração vertical (Coase, 1937).

A verticalização ocorre para economizar os riscos de apropriação de quase-rendas associadas à existência de ativos específicos (Klein, Crawford \& Alchian, 1978). Como dito anteriormente, a especificidade de ativos é vista como investimentos específicos para uma transação em particular que perdem valor com o seu uso em relacionamentos alternativos (Williamson, 1981), a qual possui níveis de especificidade distintos: ativos idiossincráticos, com nível intermediário de especificidade e com possibilidade de uso alternativo sem perda de valor. A classificação dessa característica na transação de colheita mecanizada na cafeicultura é envolta de especificidade de ativos de naturezas distintas. A alocação de recursos no produto transacionado (colheitadeira) - seja pela compra ou prestação de serviços - é associada diretamente a decisões tomadas no passado (tradição da família), ao perfil do produtor rural (localização, escolaridade), aos investimentos de capacitação na mão de obra que irá operar os equipamentos, à adaptação da infraestrutura da propriedade (escala, e montante de investimento em capital imobilizado), e o timing na atividade da colheita.

A especificidade humana de ativos assume importância pelo know-how necessário para operar as colheitadeiras do café. A especialização para conduzir os maquinários com eficiência exige um nível de investimentos em treinamentos para prestação do serviço. A exigência de aplicação de recursos para desenvolvimento do condutor aumenta seu conhecimento especializado, isto é, a especificidade da transação (Lyons, 1994; Williamson, 1985).

A especificidade de ativos locacional relaciona-se com a localização dos ofertantes do serviço (Joskow, 1987; Caleman \& Zylbersztajn, 2012; Williamson, 1985). A prestação de 
serviço de colheita mecanizada depende diretamente da distância entre os fornecedores e do cafeicultor demandante. O custo com o transporte dos equipamentos até o cafezal é elevado. Quanto maior a distância do produtor e do prestador de serviço maior será o valor dissipado em virtude da despesa exigida. Diferentemente de outras culturas, como no caso da soja, as prestadoras de serviços de mecanização da colheita para o café estão concentradas em determinadas regiões, ou seja, não transitam ao longo do território brasileiro durante a época da colheita, o que torna a sua distância até o cafeicultor como um fator relevante. Portanto, a topografia plana do terreno e o distanciamento entre os agentes demonstram especificidade locacional.

A especificidade de ativos físicos é visualizada pelos investimentos específicos em equipamentos (Joskow, 1987; Lyons, 1994; Mascarin, 2014; Williamson, 1985). O cafeicultor que possui investimentos em ativos específicos para a colheita tende a tomar a decisão de verticalização. A estrutura de capital imobilizado em máquinas caracteriza maior especificidade em face da potencialização da escala com a integração vertical.

A especificidade temporal também é presente na atividade da colheita do café. A demora na realização dessa operação traz perdas para o produtor em razão da diminuição da qualidade do grão, assim, os dias de atraso para colher o café podem acarretar uma perda substancial de valor. Portanto, a especificidade quanto ao tempo surge em situações de sensibilidade nos atrasos (Masten, 2000; Williamson, 1985).

Conforme mencionado, diferentes tipos de especificidades de ativos influenciam a transação com a indústria de mecanização agrícola na colheita da cultura cafeeira. Em um relacionamento com alto grau de especialização, o anseio da coordenação se pauta na possibilidade de hold-up (Klein, Crawford \& Alchian, 1978; Williamson, 1985, 1996). Em uma transação com elevada especificidade de ativos, há maior geração de quase-renda, o que induz a coordenação estrita-hierárquica. A estrutura de governança mais hierárquica terá melhor proteção dos investimentos e menores custos de transação. Tal relação é presente na transação de colheita mecanizada no SAG do café e permite gerar a primeira hipótese do projeto:

$\mathrm{H}_{1}$ : Quanto maior a especificidade de ativos envolvida na transação de colheita mecanizada, maior será a tendência de adoção de maquinário e serviço próprio.

A característica de incerteza na transação é exposta pela incapacidade de prever um acontecimento, ou melhor, o desconhecimento da função de distribuição de probabilidade do 
fenômeno (Williamson, 1985, 1996). Esse atributo é associado à coordenação das transações nos sistemas agroindustriais por meio do ambiente institucional e da estrutura tecnológica do setor (Zylbersztajn, 1996). O ambiente institucional é construído pelas instituições formais e informais, as quais podem reduzir ou aumentar custos de transação e incerteza, além de potencializar ou diminuir o desempenho econômico das transações envolvidas (North, 1991). As instituições podem ter papel político ou econômico, caráter formal (legislações, normais e decretos) ou informal (costumes, cultura, tradições).

Todavia, mesmo que as instituições tenham essa capacidade de minimização de incerteza, elas atuam por meio da interpretação da legislação vigente por indivíduos, ou seja, os seus representantes possuem limitações devido às características da racionalidade limitada. A ocorrência desse fator é dada pela capacidade de deter, processar e analisar todas as informações necessárias para construção de um ambiente com nenhuma incerteza (Simon, 1955). Além deste pressuposto, emerge a dificuldade de mensuração, avaliação das cláusulas contratuais e as métricas dos contratos como determinantes do nível de incerteza. Diante disso, o enforcement realizado por tribunais pode ser falho por causa dessas características, o que acarreta uma maior descrença na utilização de mecanismos formais em algumas negociações (Hermalin, Katz \& Craswell, 2007).

Mascarin (2014) mostra falhas na legislação trabalhista brasileira no uso da subcontratação de serviços de equipamentos agrícolas. A autora destaca que a atuação do Ministério do Trabalho do Brasil caracteriza o ambiente institucional como incerto, pois não há um padrão de decisões quanto à proibição ou não da subcontratação desse serviço dentro de uma propriedade rural. Essa instabilidade é consequência de mudanças em andamento na legislação que trata sobre a terceirização de atividades ${ }^{6}$. Devido à falta de aplicação dessas normas como lei, alguns processos são julgados pela decisão do tribunal a favor do contrato externo, enquanto em outros a subcontratação de serviços de mecanização da colheita por parte dos agricultores é considerada ilegal e passível de punição. Com base nessa perspectiva a transação é afetada pela incerteza gerada por diferentes interpretações nos tribunais (Hermalin, Katz \& Craswell, 2007).

Dessa maneira, a complexidade por trás de uma análise contratual e a falta de padronização nas tomadas de decisão nos tribunais propiciam incertezas institucionais. Ceteris paribus, a opção com menores custos de transação e maior valor é o arranjo com menor exigência de formalidade (Williamson, 1996). Portanto, ao considerar o atributo da

\footnotetext{
${ }^{6}$ A proposta a favor da externalização de atividades-fim para uma organização produtiva está em análise no Congresso Nacional Brasileiro pelo Projeto de Lei 4330/2004.
} 
incerteza, a necessidade de integração vertical ocorre apenas no caso de um ambiente com dificuldades nessa previsão, isto é, o cafeicultor só é desencorajado de usar os contratos ao enfrentar um cenário que traga esse caráter de imprevisibilidade. Com base nesses expostos, forma-se segunda hipótese da pesquisa:

$\mathrm{H}_{2}$ : Quanto maior a incerteza institucional na transação de colheita mecanizada, maior será a tendência de adoção de maquinário e serviço próprio.

Os eventos ocorridos em experiências passadas também interferem no presente, na escolha do arranjo institucional da transação de colheita mecanizada pelo cafeicultor. As tomadas de decisões ao longo do tempo constroem uma rota que limita as opções de negociações futuras a partir de uma estrutura passada já definida, o que determina a dependência de rota (path dependence). O conceito mostra que os relacionamentos anteriores podem direcionar o futuro com base nas perdas, no ato de quebra dessa dependência. $\mathrm{O}$ equilíbrio entre os benefícios em continuar a adotar a estrutura já utilizada no passado e os custos de adentrar em um novo percurso ressalta a impossibilidade de mudança (North, 1990).

$\mathrm{O}$ path dependence pode limitar as escolhas racionais dos agentes econômicos. Esse atributo traz a influência entre as decisões de curto e longo prazo. Um exemplo pode ser a alocação exacerbada de recursos em uma atividade específica, a qual não poderá ser ignorada em razão dos investimentos realizados em tais processos produtivos ou, caso contrário, o agente terá que lidar com a perda dos recursos alocados. Porém, mesmo com tal limitação nas escolhas, a realidade é pautada em um mundo não ergódico (North, 1990), ou seja, o sistema econômico não é estacionário e as decisões mudam drasticamente a depender do funcionamento do mercado.

.Esse cenário se aplica ao recorte adotado no estudo. Os investimentos específicos em colheitadeiras realizados no passado pode limitar a possibilidade de subcontratação no presente. Essa limitação é resultado de situações em que produtores que tomaram empréstimos e os alocaram em recursos específicos, por exemplo. Esse cafeicultor possui restrições na tomada de decisão, pois, além da especificidade da colheitadeira que limita seu uso alternativo, o produtor pode carregar dívidas que podem levar anos para serem finalizadas. Dessa forma, o cafeicultor com esta característica dificilmente irá subcontratar e arcar com os pagamentos das horas de serviço prestado, visto que já possui o próprio maquinário, podendo, ainda, estar endividado por esta razão. 
A aplicação do path dependence na transação de colheita mecanizada é assumida pela experiência do cafeicultor na atividade. Os anos na atividade da cafeicultura e o conhecimento transmitido pelas gerações podem influenciar a decisão de adotar ou não subcontratação (North, 1990). O histórico da cafeicultura brasileira demonstra que a transação de colheita mecanizada foi integrada verticalmente desde sua origem (Silva \& Salvador, 1998). O contato por um longo período com a atividade faz com que o produtor mantenha as tradições de uso de maquinário próprio. $\mathrm{O}$ sucessor de um cafeicultor que já detém os próprios equipamentos pode sofrer influência para manter essa prática. Portanto, esse fator traz a tendência de verticalização nessa transação, apresentando a terceira e última hipótese da pesquisa:

$\mathrm{H}_{3}$ : Quanto maior o nível de path dependence do cafeicultor, maior será a tendência de adoção de maquinário e serviço próprio na transação de colheita mecanizada.

\subsection{Considerações finais do capítulo}

Este capítulo teve o objetivo de apresentar a literatura da Economia de Custos de Transação e Sistemas Agroindustriais, a literatura - mundial e brasileira - que trata da subcontratação de mecanização da colheita agrícola, além de expor os possíveis determinantes sob a ótica da cafeicultura com a Economia de Custos de Transação como pano de fundo.

A seção apresentou tanto determinantes de diferentes culturas que interferem positivamente na subcontratação de mecanização da colheita, quanto os fatores que implicam a utilização dos maquinários próprios. A partir dessa exposição foram elaboradas três hipóteses a serem exploradas no modelo econométrico. O próximo capítulo traz a metodologia utilizada em todas as etapas da investigação. 


\section{METODOLOGIA}

O presente capítulo expõe os métodos adotados durante o desenvolvimento das etapas da investigação. O estudo adotou uma abordagem mista, qualitativa e quantitativa, conforme apresentado no Quadro 1.

Quadro 1 - Estrutura da metodologia do estudo

\begin{tabular}{|c|c|c|c|c|}
\hline \multicolumn{2}{|c|}{ Universo da Pesquisa } & \multicolumn{3}{|c|}{ Sistema Agroindustrial do Café } \\
\hline \multicolumn{2}{|c|}{ Objeto de Estudo } & \multicolumn{3}{|c|}{ Mecanização da colheita agrícola } \\
\hline \multicolumn{2}{|c|}{ Unidade de Análise } & \multicolumn{3}{|c|}{ Transação da mecanização da colheita na cafeicultura } \\
\hline \multicolumn{2}{|c|}{ Abordagem } & \multicolumn{3}{|c|}{ Qualitativa e Quantitativa } \\
\hline Capítulos & $\begin{array}{l}\text { Objetivos } \\
\text { específicos }\end{array}$ & $\begin{array}{l}\text { Natureza da } \\
\text { pesquisa }\end{array}$ & Procedimentos & $\begin{array}{c}\text { Técnica de coleta de } \\
\text { dados }\end{array}$ \\
\hline Capítulo 4 & $\mathrm{i}$ & $\begin{array}{l}\text { Exploratória e } \\
\text { descritiva }\end{array}$ & $\begin{array}{c}\text { Pesquisa } \\
\text { bibliográfica e } \\
\text { documental }\end{array}$ & $\begin{array}{l}\text { Levantamentos de } \\
\text { dados primários via } \\
\text { entrevistas em } \\
\text { profundidade } \\
\text { levantamento de dados } \\
\text { secundários (anuários } \\
\text { de associações das } \\
\text { classes, relatórios } \\
\text { técnicos, base de dados } \\
\text { do IBGE e do MAPA, } \\
\text { periódicos acadêmicos } \\
\text { e livros) }\end{array}$ \\
\hline Capítulo 5 & ii & $\begin{array}{c}\text { Exploratória e } \\
\text { descritiva }\end{array}$ & $\begin{array}{c}\text { Pesquisa } \\
\text { bibliográfica e } \\
\text { documental }\end{array}$ & $\begin{array}{l}\text { Levantamento de } \\
\text { dados secundários } \\
\text { (base de dados do } \\
\text { BNDES e do MPT, } \\
\text { portais de notícias de } \\
\text { entidades relevantes da } \\
\text { cafeicultura, periódicos } \\
\text { acadêmicos e livros) }\end{array}$ \\
\hline Capítulo 6 & iii & Explicativa & Pesquisa de campo & $\begin{array}{l}\text { Levantamento de } \\
\text { dados primários } \\
\text { (Survey in locu e via } \\
\text { telefone) }\end{array}$ \\
\hline
\end{tabular}

Fonte: Elaborado pelo autor.

A abordagem qualitativa de natureza descritiva e exploratória municiou os resultados do primeiro e segundo objetivos específicos. Os dados utilizados são primários e secundários. Os dados primários foram coletados por entrevistas em profundidade com 10 cafeicultores ao longo do estado de Minas Gerais (Cerrado Mineiro, da Chapada de Minas, do Sul de Minas e 
Região das Matas Mineiras) e Espírito Santo. Essa decisão possibilitou a construção do cenário das diferentes propriedades cafeeiras do Brasil a partir da lente da produção agrícola, pois essas regiões trazem as principais características encontradas em outras lavouras de café ao longo de outros estados brasileiros, tais como São Paulo, Bahia e Rondônia. Os dados secundários foram coletados em documentos bibliográficos e informações advindas de organizações relevantes para o setor brasileiro de café. O caráter de descrição é associado ao objetivo específico " $i$ ", o qual visa apresentar o quadro atual do Sistema Agroindustrial (SAG) do Café no Brasil a partir do modelo adotado pelo PENSA. Já o recorte do objetivo específico "ii" visou analisar as interferências que os ambientes institucional e organizacional têm sobre a decisão de integrar verticalmente as operações de mecanização da colheita. Portanto, a contribuição dessa seção volta-se à atualização dos novos entrantes e no surgimento de estratégias diferenciadas, além de contribuir para a elaboração de políticas públicas e estratégias privadas e para a compreensão dos choques externos nas estratégias entre ambos os agentes, ou seja, o entendimento das interferências que moldam a organização econômica desse ambiente e modificam a coordenação da transação.

A abordagem quantitativa se associa ao objetivo "iii" na exposição dos resultados obtidos pelo modelo econométrico. A fundamentação é baseada em uma abordagem quantitativa e com caráter explicativo. Os dados utilizados são primários e obtidos por meio de uma survey com um instrumento de coleta pautada na literatura da ECT (Apêndice 1).

O questionário passou por um processo de validação durante o período de julho a setembro de 2015, o qual foi feito por dois especialistas do mercado de café. Foi realizado um pré-teste com uma coleta de 30 observações durante a Semana Internacional do Café, um evento que reúne uma diversidade de perfis de cafeicultores brasileiros, em setembro de 2015, e mais 39 observações para verificar o comportamento do cafeicultor na coleta via telefone.

Após alterações em razão do pré-teste, aplicou-se novamente o questionário e foi formada uma amostra de 105 observações com natureza não probabilística. A coleta dos dados foi realizada apenas com cafeicultores com colheita mecanizada, seja subcontratada, seja com máquinas próprias. Os produtores entrevistados são dos estados de Minas Gerais e São Paulo, pois essas são as duas principais regiões de produção de café no Brasil e possuem a variedade de estrutura produtiva encontrada em outros estados. Dessa forma, os questionários foram respondidos por cafeicultores de café arábica que trazem as diferentes características de lavoura de café e dos processos de colheita mecanizada encontrados no país.

Para a análise desse recorte, partiu-se da hipótese de que eficiência econômica decorre das características da transação e da escolha da governança, com base no conceito de 
alinhamento eficiente de Williamson $(1985,1991)$ e da literatura acerca de subcontratação de mecanização agrícola.

As hipóteses são apresentadas no Quadro 2, enquanto as métricas são detalhadas na próxima subseção e o modelo econométrico na sequência.

Quadro 2 - Hipóteses teóricas a partir da Economia de Custos de Transação.

\begin{tabular}{|c|c|}
\hline Hipótese & Descrição \\
\hline$H_{1}$ & $\begin{array}{l}\text { Quanto maior a especificidade de ativos envolvida na transação de } \\
\text { colheita mecanizada, maior será a tendência de adoção de maquinário e } \\
\text { serviço próprio. }\end{array}$ \\
\hline $\mathrm{H}_{2}$ & $\begin{array}{c}\text { Quanto maior a incerteza institucional na transação de colheita } \\
\text { mecanizada, maior será a tendência de adoção de maquinário e serviço } \\
\text { próprio. }\end{array}$ \\
\hline$H_{3}$ & $\begin{array}{l}\text { Quanto maior o nível de path dependence do cafeicultor, maior } \\
\text { será a tendência de adoção de maquinário e serviço próprio na } \\
\text { transação de colheita mecanizada. }\end{array}$ \\
\hline
\end{tabular}

Fonte: Elaborado pelo autor.

\subsection{Métricas na decisão de subcontratação}

As métricas escolhidas são baseadas na literatura que trata da subcontratação de mecanização agrícola (Capítulo 2), tendo a Economia de Custos de Transação como pano de fundo. Dessa forma, a estrutura da subseção é pautada nas hipóteses do estudo (Quadro 2) com o seguinte ordenamento: especificidade de ativos, incerteza institucional, nível de path dependence e variáveis de controle. A apresentação das métricas é feita no Quadro 3, que contém a associação da métrica com a variável teórica, a relação com a hipótese, a questão do instrumento de coleta de dados utilizada (Apêndice 1), a natureza do indicador, o sinal esperado no modelo e a referência de uso similar na literatura. 
Quadro 3 - Síntese das variáveis da regressão probit de subcontratação de colheita mecanizada.

\begin{tabular}{|c|c|c|c|c|c|}
\hline Variável & Hipótese / Métrica & Questão & Natureza & Sinal & Referência \\
\hline Dependente & $\begin{array}{l}1=\text { subcontratação de serviços de colheita mecanizada } \\
0=\text { uso de serviços próprios (máquina e empregado) }\end{array}$ & & Dummy & --- & --- \\
\hline \multirow{2}{*}{$\begin{array}{l}\text { Especificidade } \\
\text { Humana }\left(\mathrm{H}_{1}\right)\end{array}$} & $\begin{array}{l}\text { Quanto maior a necessidade de anos de experiência para } \\
\text { condução eficiente do maquinário, maior é a utilização de } \\
\text { maquinários próprios (exp_moto) }\end{array}$ & Q. 16 & $\begin{array}{l}\text { Discreta (em } \\
\text { anos) }\end{array}$ & - & Lyons (1994) \\
\hline & $\begin{array}{l}\text { Quanto maior a importância do treinamento para conduzir o } \\
\text { maquinário, maior é a utilização de maquinários próprios } \\
\text { (trei_moto) }\end{array}$ & Q. 17 & $\begin{array}{c}\text { Ordinal (escala } 5 \\
\text { pontos) }\end{array}$ & - & Lyons (1994) \\
\hline \multirow[t]{2}{*}{$\begin{array}{l}\text { Especificidade } \\
\text { Locacional } \\
\left(\mathbf{H}_{1}\right)\end{array}$} & $\begin{array}{l}\text { A existência de prestadora de serviço na região ameniza a } \\
\text { especificidade locacional e possibilita a subcontratação } \\
\text { (exist_prest) }\end{array}$ & Q.24 & Dummy & + & $\begin{array}{l}\text { Caleman e Zylbersztajn } \\
\text { (2012); Zylbersztajn e } \\
\text { Miele } \\
\text { Zylbersztajn e Lazzarini } \\
\text { (2005). }\end{array}$ \\
\hline & $\begin{array}{l}\text { Quanto maior a distância da prestadora de serviço maior será a } \\
\text { especificidade locacional e, consequentemente, maior será o uso } \\
\text { dos equipamentos próprios. (dist_prest) }\end{array}$ & Q.25 & $\begin{array}{c}\text { Contínua } \\
\text { (em quilômetros) }\end{array}$ & - & $\begin{array}{l}\text { Caleman e Zylbersztajn } \\
(2012) ; \text { Zylbersztajn e } \\
\text { Miele } \\
\text { Zylbersztajn e Lazzarini } \\
\text { (2005). }\end{array}$ \\
\hline $\begin{array}{l}\text { Especificidade } \\
\text { Física } \\
\left(\mathbf{H}_{1}\right)\end{array}$ & $\begin{array}{l}\text { Quanto maior o valor investido em maquinários específicos para } \\
\text { colheita na cafeicultura, maior a especificidade de ativos e, } \\
\text { portanto, maior o uso dos equipamentos próprios. } \\
\text { (log_val maqprop) }\end{array}$ & Q.14 & $\begin{array}{l}\text { Contínua } \\
\text { (logaritmo natural } \\
\text { do valor em reais) }\end{array}$ & - & $\begin{array}{l}\text { Lyons (1994); Joskow } \\
\text { (1987) }\end{array}$ \\
\hline \multirow[t]{2}{*}{$\begin{array}{l}\text { Especificidade } \\
\text { Temporal }\left(\mathrm{H}_{1}\right)\end{array}$} & $\begin{array}{l}\text { Quanto maior for a percepção de risco de perda de valor devido a } \\
\text { atrasos na colheita, maior a especificidade temporal e, por essa } \\
\text { razão, maior será o uso dos equipamentos próprios } \\
\text { (atra_colheita) }\end{array}$ & Q.20 & $\begin{array}{c}\text { Ordinal } \\
\text { (escala } 5 \text { pontos) }\end{array}$ & - & Masten (2000) \\
\hline & $\begin{array}{l}\text { A existência de termos de ajustamento de conduta na região da } \\
\text { propriedade indica barreiras e incerteza institucional, dessa forma, } \\
\text { implica o uso de máquinas próprias (exist_tac) }\end{array}$ & Q.1* & Dummy & - & $\begin{array}{l}\text { Mascarin } \quad(2014) \\
\text { Hermalin, Katz } \\
\text { Craswell }(2007)\end{array}$ \\
\hline
\end{tabular}




\begin{tabular}{|c|c|c|c|c|c|}
\hline \multirow{2}{*}{$\begin{array}{l}\text { Incerteza } \\
\qquad\left(\mathrm{H}_{2}\right)\end{array}$} & $\begin{array}{l}\text { A existência de problema judicial trabalhista indica barreiras e } \\
\text { incerteza institucional, dessa forma, implica o uso de máquinas } \\
\text { próprias (prob_trab) }\end{array}$ & Q.29 & Dummy & - & $\begin{array}{l}\text { Mascarin } \quad(2014) \\
\text { Hermalin, } \quad \text { Katz } \\
\text { Craswell (2007) }\end{array}$ \\
\hline & $\begin{array}{l}\text { O uso de contratação para outros serviços indica maior } \\
\text { competência para gestão de conflitos contratuais, logo, implica } \\
\text { menor incerteza e maior uso de subcontratação (out_cont) }\end{array}$ & Q.30 & Dummy & + & $\begin{array}{l}\text { Hermalin, Katz } \\
\text { Craswell (2007) }\end{array}$ \\
\hline \multirow{2}{*}{$\begin{array}{l}\text { Path } \\
\text { Dependence } \\
\quad\left(\mathrm{H}_{3}\right)\end{array}$} & $\begin{array}{l}\text { Ter tradição na cafeicultura implica maior conservadorismo nas } \\
\text { atitudes do produtor, consequentemente, maior é o uso das } \\
\text { máquinas próprias pela continuidade da rota de dependência } \\
\text { (tradição_fam) }\end{array}$ & Q.6 & $\begin{array}{l}\text { Dummy } \\
(\geq \text { terceira } \\
\text { geração=1) }\end{array}$ & - & $\begin{array}{l}\text { North }(1990) \text { e Silva e } \\
\text { Salvador (1998) }\end{array}$ \\
\hline & $\begin{array}{l}\text { Maior tempo na atividade de cafeicultura implica maior } \\
\text { conservadorismo nas atitudes do produtor, logo, maior é o uso das } \\
\text { máquinas próprias pela continuidade da rota de dependência. } \\
\text { (temp_cafe) }\end{array}$ & Q.3 & $\begin{array}{l}\text { Discreta } \\
\text { (em anos) }\end{array}$ & - & $\begin{array}{l}\text { North }(1990) \text { e Silva e } \\
\text { Salvador (1998) }\end{array}$ \\
\hline \multirow{4}{*}{$\begin{array}{l}\text { Variáveis de } \\
\text { Controle }\end{array}$} & $\begin{array}{l}\text { Ter nível elevado de escolaridade indica competência para } \\
\text { gerenciamento de contratos, bem como pode modificar as atitudes } \\
\text { da rota de dependência (escolaridade) }\end{array}$ & Q.2 & $\begin{array}{l}\text { Dummy } \\
\text { ( } \geq \text { Ensino } \\
\text { Superior) }\end{array}$ & + & --- \\
\hline & $\begin{array}{l}\text { O tamanho da propriedade pode implicar a diluição de custos e } \\
\text { economias de escala, isto é, quanto maior a área plantada, em } \\
\text { hectares, maior a adoção das máquinas próprias (hectares) }\end{array}$ & Q.6 & $\begin{array}{c}\text { Discreta } \\
\text { (em hectares) }\end{array}$ & - & --- \\
\hline & $\begin{array}{l}\text { A estrutura da mão de obra própria do cafeicultor interfere no } \\
\text { montante de investimentos necessários para obter a colheita } \\
\text { mecanizada, sendo assim, uma estrutura própria manual exige } \\
\text { uma imobilização de capital considerável, o que implica no uso } \\
\text { da subcontração frente a essa limitação. (mao_obra) }\end{array}$ & Q.9 & $\begin{array}{l}\text { Ordinal } \\
\text { (escala de } 3 \\
\text { pontos) }\end{array}$ & + & --- \\
\hline & $\begin{array}{l}\text { A capacidade de produzir grãos de qualidade denota competência } \\
\text { técnica, ou seja, maior é a capacidade de gestão e maior é o uso } \\
\text { de subcontratação (perc_gourmet) }\end{array}$ & Q.32 & Contínua & - & --- \\
\hline
\end{tabular}

Fonte: Elaborado pelo autor.

*Este dado foi obtido pelo cruzamento de informações da localização da cidade e a existência de TAC na região. 
A especificidade de capital humano é verificada por duas métricas: conhecimento acumulado pelas experiências do condutor; e conhecimento técnico obtido a partir de treinamentos. A primeira medida é verificada pelos anos de experiência na condução de máquinas agrícolas para o café e a segunda é uma escala de importância de treinamento do condutor. Ambos os indicadores são justificados com base no trabalho de Lyons (1994). O autor utiliza o conhecimento com moldes na indústria de manufatura e pequenos subcontratados para clientes do setor de engenharia. O estudo delimita a importância de uma firma em deter conhecimento específico interno para atenuar a complexidade do ativo. $\mathrm{Na}$ mecanização da colheita essa realidade é observada pela especialização do condutor para manter o nível ótimo produtivo. Caso esse aperfeiçoamento seja regularmente necessário, maior é a necessidade de monitoramento, logo, a atividade passa a ser verticalmente integrada ${ }^{7}$ para garantir esse acúmulo de experiências ao longo do tempo, isto é, para que o desenvolvimento ocorra sem que haja a substituição do condutor por um novo empregado como no caso de demissão e contratação em uma firma prestadora de serviço, que gera a perda do conhecimento acumulado.

A especificidade de ativos locacional é associada com a localização da prestadora de serviços de mecanização agrícola. O primeiro indicador é uma variável dummy que visa observar a existência da prestação de serviço da região do produtor. O segundo é medido pela distância em quilômetros entre a prestadora de serviço de colheita mecanizada e o produtor. A distância entre os agentes irá demandar maiores investimentos de transporte para que a transação ocorra. A referência dessa métrica é feita com base em Caleman e Zylbersztajn (2012), Zylbersztajn e Miele (2005); Zylbersztajn e Lazzarini (2005). Tais trabalhos utilizam a distância entre os agentes envolvidos na transação como um indicador para mensurar a especificidade locacional. Ao voltar à cafeicultura, a maior distância e a inexistência de um prestador de serviços na região indicam maior especificidade locacional e induzem ao uso do maquinário próprio.

A especificidade de ativos físicos relaciona-se com o valor investido nos equipamentos específicos para a cafeicultura. A métrica é o logaritmo natural ${ }^{8}$ do investimento (em reais) em maquinários próprios, tendo como referências os trabalhos de Joskow (1987) e Lyons (1994). Os autores apontaram que a imobilização do capital em equipamentos especializados denota especificidade. Não diferente, a existência de

\footnotetext{
${ }^{7}$ A firma também possui incentivos para manter o treinamento dos operadores e conservar os equipamentos. Porém, além dessa preocupação com o maquinário, o produtor busca a eficiência na operação da colheita, seja na preservação da lavoura ou de regulagem do equipamento para potencializar a atividade.

${ }^{8}$ Optou-se pelo uso do logaritmo natural devido à distribuição normal e diminuição da amplitude dos valores.
} 
investimentos em equipamentos especializados para cafeicultura expõe a existência de especificidade na transação em análise. Dessa forma, espera-se correlação negativa com a subcontratação.

A especificidade temporal é explicada pela possibilidade de perdas decorrentes de atrasos no processo de colheita. A captura dessa informação por meio do questionário é feita por uma escala de 5 pontos de ordem crescente na percepção de perda do produtor no caso de atraso na colheita. A decisão de adotar uma escala é interligada à capacidade desse tipo de variável em capturar a percepção do entrevistado, pois uma variável mais fidedigna, como por exemplo, a quantidade de dias para perda de valor é uma métrica difícil de ser mensurada pelo próprio cafeicultor. O uso desse indicador pode ser observado no trabalho de Masten (2000), no qual o autor afirma que os produtos agrícolas possuem especificidade temporal por serem perecíveis. Portanto, espera-se que, quanto maior a percepção de perda devido a um atraso na colheita, maior seja a tendência de integrar verticalmente.

Na variável 'incerteza institucional' são utilizadas as referências de Mascarin (2014) e Hermalin, Katz e Craswell (2007) com a dificuldade dos agentes do ambiente institucional em interpretar as formas de governança complexas. A métrica avalia a imprevisibilidade a partir da existência de conflitos anteriores, a convergência de soluções do Judiciário e a competência para gestão de conflitos contratuais do cafeicultor. No cenário em que o cafeicultor tenha enfrentado um processo judicial referente à legislação trabalhista espera-se que haja integração vertical da transação, pois o agente evitará enfrentar ações civis públicas pelo descumprimento dos Termos de Ajustamento de Conduta, enquanto a métrica de existência de outros contratos indica a capacidade de gestão contratual do produtor, ou seja, a adoção de outros contratos aumenta a habilidade de lidar com conflitos contratuais. Espera-se que: a) os indicadores de existência de Termos de Ajustamento de Conduta e de problema judicial trabalhista impliquem o uso das máquinas próprias; e b) o uso de contratação para outros serviços provoque maior subcontratação dos serviços de mecanização agrícola da colheita.

O path dependence foi avaliado pela tradição na atividade. As variáveis utilizadas são a tradição do produtor na cafeicultura e o tempo de experiência na atividade. A tradição é medida por uma variável dummy de $3^{\text {a }}$ geração da família na produção de café. O tempo de experiência é avaliado pelos anos de atuação. A atuação como cafeicultor por um longo período de tempo faz com que o indivíduo tenha restrições em sua tomada de decisão devido a investimentos realizados no passado como, por exemplo, tomada de empréstimos de longo prazo para aquisição de equipamentos. As experiências passadas constroem um caminho que 
pode vir a se tornar mais oneroso caso realize uma mudança no padrão previamente adotado. Esses aspectos realçam o direcionamento à integração vertical, pois o agente enfrenta uma limitação na mudança pelas escolhas feitas no passado, isto é, o tradicionalismo no ramo agrícola pode implicar maior proximidade entre o agente e suas transações de ativos físicos. $\mathrm{O}$ embasamento dessa afirmação é feito nos trabalhos de North (1990) e Silva e Salvador (1998).

Quanto às variáveis de controle, adotaram-se métricas capazes de dirimir possíveis interferências dentro do modelo. A expectativa quanto ao nível de escolaridade é o direcionamento a favor da adoção dos contratos. Esse indicador busca capturar a mudança do conservadorismo nas atitudes do produtor pelo aumento de seu conhecimento técnico na gestão financeira de seus recursos. Mesmo não se tratando de um domínio específico, a escolaridade, de modo geral, pode alavancar outras instruções especializadas, como, neste caso, o gerenciamento das transações do cafeicultor. Com o aumento da escolaridade haverá maior organização e menor complexidade no ato de contratações externas, pois o produtor com maior grau de escolaridade possui maior capacidade de gestão contratual. A estrutura de avaliação é feita através de uma variável dummy que verifica a presença do nível de escolaridade igual ou maior que o Ensino Superior ${ }^{9}$.

A quantidade de hectares de café é utilizada para verificar a economia de escala. Grandes proprietários rurais possuem maior capacidade de imobilização de capital. Os cafeicultores desse porte tendem a utilizar os maquinários próprios devido à diluição dos custos fixos que o tamanho da sua lavoura proporciona. Dessa forma, espera-se que quanto maior o número de hectares do cafezal, menor seja o uso da subcontratação.

Quanto à variável de tipologia da mão de obra espera-se observar efeito positivo com a adoção de contratos externos. Essa métrica é construída através de uma escala ordinal de 3 pontos com níveis decrescentes de uso de máquinas, isto é, parte de uma estrutura mecanizada para semimecanizada e até o nível manual. A adoção da mão de obra com menor nível de mecanização tornará menos oneroso o uso da subcontratação dos serviços de colheita mecanizada, ou seja, a estruturação de máquinas próprias torna-se mais inviável nesta situação.

A variável de controle acerca do percentual de vendas de cafés gourmet busca verificar a influência de uma transação à jusante em uma transação à montante. Espera-se que

\footnotetext{
${ }^{9}$ Optou-se pela inclusão da métrica associada ao grau de escolaridade como variável binária, pois a utilização dos anos de educação formal foi inviável. Ao analisar as respostas referentes aos anos de estudo e o grau de escolaridade, notou-se que os respondentes contradiziam o padrão de período de formação encontrado no sistema educacional brasileiro. Dessa forma, a variável contínua é descartada, pois poderia trazer resultados espúrios.
} 
quanto maior o nível de produção de grãos de café de qualidade, menor o uso de subcontratação da mecanização da colheita. A capacidade de intensificar o valor do grão cafeeiro carrega o retrato de um produtor cauteloso. A qualidade do grão, na relação com a colheita mecanizada, ocorre pela cautela na regulagem das máquinas e no uso repetido das máquinas nos mesmos pés de café, pois o valor do café se relaciona a sua maturação. Portanto, a atividade da colheita exige esses procedimentos para que as máquinas possam colher os grãos no nível correto de maturação, o que encarece os custos para uma prestadora de serviço e faz com que ela ignore essa preocupação, já que os benefícios da qualidade são apenas do produtor em si.

\subsection{Modelo Econométrico}

Foi utilizado o modelo probit cuja representação teórica está definida na Equação 1 por Green (2003). A regressão probit estima a probabilidade $\mathrm{P}(\mathrm{y}=1 \mid \mathrm{x})=\phi\left(x_{i t}{ }^{\prime} \beta\right)$, onde $\phi$ representa a função densidade cumulativa normal.

\section{Equação 1. Regressão probit}

$y_{i t}{ }^{*}=x_{i t}{ }^{\prime} \beta+\varepsilon_{i t}$

Onde,

, $Y_{i t}=1, \quad$ se $Y_{i t}^{*} \geq 0$

$y_{i t}=0, \quad$ se $y_{i t}{ }^{*}<0$

O modelo econométrico do presente estudo (Equação 2) foi construído com base no modelo teórico (Equação 1) e nas métricas da subseção anterior (Quadro 3). Os resultados encontrados no Apêndice 3 foram obtidos por meio da utilização do software STATA em sua versão 12 .

Equação 2. Regressão probit com variáveis ECT

$P($ mecanização $=1 \mid x)=\phi\left(\beta_{0}+\beta_{1} X\right.$ exp_moto $+\beta_{2} X$ trei_moto $+\beta_{3} X$ dummy_origem_prest $+\beta_{4} X$ dist prest $+\beta_{5} X \log \_v a l \_m a q p r o p+\beta_{6} X$ atra_colheita $+\beta_{7} X$ dummy_probter $+\beta_{8} X$ prob_trab $+\beta_{9}$ $X$ cont_pos $+\beta_{10} X$ tradição_dummy_fam $+\beta_{11} X$ temp_cafe $+\beta_{12} X$ dummy_escolaridade $+\beta_{13} X$ hectares $+\beta_{14} X$ mao_obra $+\beta_{15} X$ perc_gourmet $\left.+\gamma \mathrm{K}_{\text {it }}+\mathrm{e}_{\mathrm{it}}\right)$ 
Onde,

K é um vetor das variáveis de controle e $e$ são os erros aleatórios.

Mecanização $[1=$ subcontrata colheita mecanizada, $0=$ maquinários e serviço próprios]

As hipóteses apresentadas pelo cerne do estudo (Quadro 2) foram testadas pela variável dependente da subcontratação do serviço de mecanização da colheita (1), ou da integração vertical dos maquinários e serviço (0), com base nas variáveis explicativas do Quadro 3.

\subsection{Considerações finais da metodologia}

O presente capítulo apresentou o método, a técnica de coleta de dados, a natureza da abordagem adotada na construção dos capítulos, bem como especificou o modelo econométrico. As especificações referentes ao modelo foram expostas por três principais pilares, a saber: 1) o detalhamento da coleta de dados da survey; 2) a apresentação das métricas com a exposição das naturezas das variáveis, do sinal esperado, do referencial teórico e da ligação com as hipóteses da pesquisa; 3) a exibição do modelo multivariado probit teórico e a regressão probit utilizada nas análises.

A metodologia serviu de base para as três próximas seções que são responsáveis pela exposição dos resultados. O próximo capítulo traz o SAG do café revisitado. No capítulo 5 há o afunilamento para a transação entre o cafeicultor e a indústria de máquinas com a exposição dos ambientes institucional e organizacional do relacionamento. E posteriormente, o capítulo 6 traz as estatísticas descritivas da amostra estudada e os resultados do modelo econométrico. 


\section{REVISITANDO O SISTEMA AGROINDUSTRIAL (SAG) DO CAFÉ}

O presente capítulo descreve o SAG do café no Brasil. Para tanto é utilizado o modelo PENSA ${ }^{10}$, composto por 04 etapas: a análise dos setores, das transações, do ambiente institucional e do ambiente organizacional.

O modelo utiliza o embasamento do conceito de SAG e da teoria de Economia de Custos de Transação (características da transação, pressupostos comportamentais, ambiente institucional e organizacional).

\subsection{Sistema Agroindustrial do Café no Brasil}

A apresentação das transações do SAG de Café no Brasil é feita ao longo desta seção com base na Figura 3. Inicialmente é feita a exposição da estrutura das indústrias e, em seguida, são apresentados os relacionamentos relevantes para a cadeia, principalmente sob o enfoque da produção agrícola.

\footnotetext{
${ }^{10}$ Este é um modelo analítico desenvolvido para estudos de Sistemas Agroindustriais pelo grupo de pesquisa PENSA - Conhecimento em Agronegócios da Faculdade de Economia, Administração e Contabilidade (FEA) da Universidade de São Paulo (USP).
} 
Figura 3 - Sistema Agroindustrial de Café no Brasil

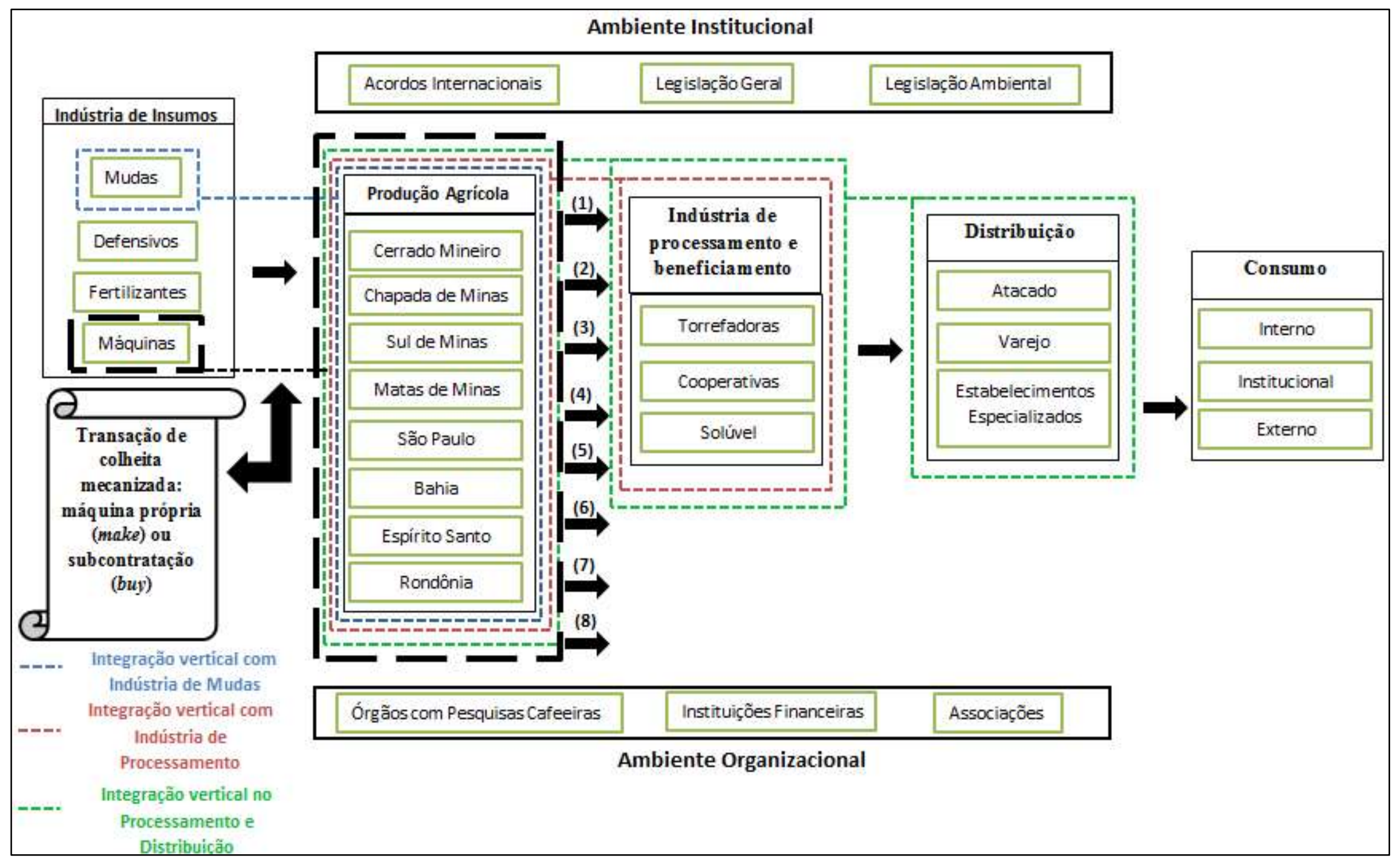

Fonte: Elaborado pelo autor 


\subsubsection{Análise dos Setores}

A Figura 3 ilustra o Sistema Agroindustrial do Café no Brasil por meio das transações e dos setores correlacionados. A observação dessa cadeia é embasada pela lógica dos Sistemas Agroindustriais (SAG) e Economia de Custos de Transação (ECT). A junção de ambos os construtos realça a análise sistêmica do modelo PENSA, com início nos insumos até o limite à jusante com o consumidor final - sendo todas essas transações coordenadas com influências do ambiente institucional (leis, normas) e organizacional (suporte de pesquisa, financeiro, certificação) (Neves \& Caleman, 2015).

Dessa forma, inicia-se a apresentação detalhada dos setores e das transações típicas do Sistema Agroindustrial de Café no Brasil.

O SAG do café brasileiro passou por desregulamentação durante a década de 90 , bem como foi influenciado pela política econômica de abertura comercial. A partir de tais mudanças, estratégias organizacionais emergiram como resposta às novas oportunidades (Zylbersztajn et al., 1993). Um caso é o aumento da competividade do café do tipo commodity como forma de manter o Brasil na liderança produtivo mundial (MAPA, 2016a). Nota-se que o desenvolvimento do setor se deu principalmente pela diminuição de custos de produção, pelas alterações nas etapas produtivas da cafeicultura: plantio (adaptação de mudas cafeeiras), colheita (desenvolvimento de colheitadeiras e adequações, assim como, criação de equipamentos eficientes e de menor porte para entender cafezais em regiões acidentadas), prébeneficiamento (máquinas capazes de aumentar qualidade do grão a partir de processos de lavagem, descascamento, despolpamento, entre outros), pelas alterações na organização econômica dos setores envolvidos (Saes e Farina, 1999).

Indústria de Mudas - Na cafeicultura brasileira distinguem-se a existência do café arábica e o café robusta, sendo o desenho da produção de ambas as espécies consideravelmente semelhantes.

A indústria de mudas de café vem demonstrando ser o setor de insumos com menos obstáculos no relacionamento com o cafeicultor. A organização da produção é formada por um número elevado de produtores de mudas com pequenas diferenciações. A concentração do mercado é mínima e com atuação local. Os principais estados cafeicultores produzem suas próprias mudas (MAPA, 2003a).

O retrato do setor é construído por meio de dados disponibilizados pelas Superintendências Federais de Agricultura do Brasil. No estado de Minas Gerais existem mais 
de 1500 produtores de mudas ao longo das quatro regiões produtoras (Cerrado, Matas, Chapada, Sul de Minas), sendo a capacidade produtiva equilibrada e, consequentemente, sem possibilidade de nomeação de líderes de mercado. O retrato se assemelha em outros estados, porém em menores proporções. Outros casos são o estado de São Paulo com mais de 60 viveiros de mudas e a Bahia com mais de 10, ambos com capacidade produtiva regular. Ainda, a exemplificação se repete com outros agentes importantes, como os estados do Espírito Santo e Rondônia com mais de 270 viveiros com a espécie do café robusta - foco principal da cafeicultura dessas regiões. Dessa forma, a estrutura que permeia esse agente é envolta de uma organização desconcentrada e difusa ao longo do território brasileiro (MAPA, 2003a)

De modo geral, a formação do preço das mudas segue as oscilações de oferta e demanda do mercado, já que a tecnologia adotada é difundida e com pouca diferenciação entre os produtores. O padrão produtivo são as opções de material genético disponibilizadas pelos agentes do ambiente organizacional (ex: órgãos de pesquisa e de extensão rural, EMBRAPA, IAC e outros) para todos os viveiros. Logo, o preço é delimitado a partir dos custos de produção, pois há impossibilidade de uso do poder de mercado, haja vista a desconcentração e a inexistência de uma brusca diferenciação tecnológica.

Indústria de Fertilizantes - Segundo dados da Associação Nacional para Difusão de Adubos (ANDA, 2015b) foram vendidas 13.181 mil toneladas de fertilizantes durante o período de janeiro a junho de 2016 , um acréscimo de $12,6 \%$ em relação ao ano de 2015 . O produto é uma mistura de nutrientes (nitrogênio - $\mathrm{N}$, fósforo - $\mathrm{P}$, potássio - $\mathrm{K}$ e outros). Considerando essa divisão e as quantidades de cada nutriente, surgem as categorias dos fertilizantes como: nitrogenados, fosfatados e potássicos, com funcionamento similar em seus mercados (ANDA, 2015a).

O processo produtivo do fertilizante complexo ocorre pela mistura das partículas granuladas e forma o NPK. A produção é fortemente dependente da importação, visto que cerca de 70\% dos insumos são importados. (ANDA, 2015a).

Assim como a obtenção dos insumos (fertilizantes simples) advém da concentração nas empresas Vale e Petrobrás, a produção dos fertilizantes misturados é regionalmente concentrada, tendo a região centro-sul do Brasil 85,6\% da parcela total de fertilizante do país. Mesmo que a comercialização dos fertilizantes conte com a presença de 105 diferentes misturadoras com difusão geográfica e atuação em diferentes culturas, as formulações finais do NPK no mercado agrícola brasileiro se concentram na margem de $70 \%$ em quatro grandes 
grupos: Bunge, Mosaic, Heringer e Yara (Banco Nacional de Desenvolvimento Econômico e Social [BNDES], 2012b).

A cafeicultura representou cerca de $15 \%$ da demanda de fertilizantes na agricultura brasileira em 2012, tendo um aumento crescente durante a última década. (BNDES, 2012). Mesmo com uma perspectiva positiva de crescimento, a atividade ocupa a $4^{\mathrm{a}}$ posição na demanda de fertilizantes, atrás das culturas de soja, milho e cana-de-açúcar.

Mesmo com participação relevante no mercado de fertilizantes, a formação do preço do produto para a cafeicultura depende do tipo de fertilizante. O preço está associado a fatores macroeconômicos, tais como variações de câmbio, preço do petróleo, custos portuários, tributos externos e internos.

Além disso, de modo semelhante ao relacionamento com a indústria de máquinas, o cafeicultor pode utilizar sacas de café como indicador monetário na compra de fertilizantes, dado que o café é uma cultura com forte absorção das vendas do setor (BNDES, 2012b).

Voltado à tecnologia do setor, retrata-se que o produto não possui diferenciação. Os processos produtivos ocorrem por meio de equipamentos já conhecidos pelas empresas. $\mathrm{O}$ mecanismo de mudança tecnológica se dá pelo processo de aplicação do produto - absorção rápida ou lenta no solo ou na folha - e pela assistência técnica oferecida aos produtores rurais.

Indústria de Defensivos - O registro dos defensivos agrícolas no Brasil é feito pelo Sistema de Agrotóxicos Fitossanitários (AGROFIT) do Ministério da Agricultura, Pecuária e Abastecimento (MAPA). O sistema apresenta o registro de 439 produtos agrotóxicos classificados para a cultura do café. Quanto às classes é observada a presença mais marcante das variações entre os produtos, como: 104 inseticidas (produtos à base de substâncias químicas ou agentes biológicos destinados a eliminar insetos), 94 fungicidas (agentes físicos, químicos ou biológicos destinados a combater os fungos), 66 herbicidas (produtos destinados a eliminar ervas daninhas ou impedir o crescimento delas) (MAPA, 2016b).

Quanto ao setor brasileiro de defensivos agrícolas, o país possui relevante participação na demanda mundial desses produtos. A agricultura brasileira foi responsável pelo consumo de 87 mil toneladas e US\$ 9,6 bilhões em vendas de produtos comerciais no ano de 2015. A categoria com maior participação foram os inseticidas com US\$ 3,17 bilhões e 33\% do mercado total, seguidos pelos herbicidas com US\$ 3,1 bilhões e 32\%, além dos fungicidas com US\$ 2.9 bilhões e $30 \%$, e as demais classes com US\$ 0,44 bilhões e $5 \%$ (Neves, 2016). 
A demanda é atendida por uma organização concentrada da produção. O setor apresenta uma estrutura de mercado de oligopólio. O nível de concentração das quatro maiores firmas (CR4) chega a 66\%. A indústria de defensivos agrícolas brasileiras é dominada por empresas globais. As líderes desse mercado são agentes mundialmente atuantes e reconhecidas pelos fortes investimentos em desenvolvimento e pesquisa.

Tais líderes de mercado possuem suas tecnologias parcialmente protegidas. De acordo com Neves (2016), cerca de 60\% da produção é protegida por patentes, sendo as classes de fungicidas e inseticidas as maiores representantes nesse meio, enquanto $40 \%$ do mercado embasam-se em produtos genéricos e sem proteção, tendo os herbicidas com maior participação.

Além dessa divisão de proteção de direitos de propriedade, a indústria de defensivos pode ser analisada sob dois enfoques. Primeiro, quanto à fabricação de ingrediente ativo, conhecido por "produto técnico" ou "princípio ativo", isto é, substância unimolecular com propriedades físicas e químicas definidas. E, segundo, quanto à formulação de produtos com esse ingrediente ativo, ou seja, foco produtivo em processos físicos, como diluição, moagem e mistura com outros componentes (ex: solventes, emulsificantes) para diluição ou estabilização do ingrediente ativo, cujo produto final é utilizado nas lavouras (BNDES, 2012a).

Observa-se que as produtoras globais tendem a concentrar a fabricação dos ingredientes ativos em apenas uma planta industrial, a responsável pela distribuição para as produtoras de formulação que atuam de modo mais amplificado com localizações próximas dos seus mercados, desfrutando de economias de escala. No Brasil, esse cenário se mantém. A indústria de defensivos brasileira é mantida principalmente pela importação das moléculas para posterior formulação. Contudo, há algumas exceções na produção inteiramente no território brasileiro, como no caso da Monsanto em Camaçari (BA) e a Basf em Guaratinguetá (SP) (Everylog, 2013).

A produção dos defensivos agrícolas no território brasileiro possui um sistema de distribuição que se estrutura em três níveis (BNDES, 2012a). Primeiro, a venda direta para grandes produtores rurais, que foi responsável por $26 \%$ do valor das vendas no ano de 2012 , conforme BNDES (2012a). Segundo, a venda via cooperativas ou distribuidores que revendem ao agricultor, que obteve $24 \%$ do faturamento no mesmo ano. E terceiro, quando os produtos são vendidos via atacadistas que assumem a função de intermediário ao revender aos agentes independentes ou cooperativas menores, que posteriormente vendem aos agricultores, sendo esse nível o mais representativo no mercado de defensivos agrícolas brasileiro, com $50 \%$ de participação. 
Percebe-se a importância das revendas em razão das políticas de investimentos adotadas pelas grandes corporações do mercado de defensivos. Tal estrutura de distribuição de três níveis influencia diretamente a formação do preço do produto.

O preço dos defensivos não patenteados sofre interferências de fatores macroeconômicos, assim como na indústria de fertilizantes. Os custos tributários, logísticos e as flutuações de câmbios são considerados. Tais custos tornam o uso de revendedores mais atrativo em relação a um investimento local, ou seja, a fabricação de novos produtos e a área de pesquisa e desenvolvimento são mantidas centralizadas na matriz das empresas.

O preço dos defensivos patenteados segue a lógica do monopólio "artificial", portanto as marcas possuem espaço, seja na imposição de preços ou diferenciação tecnológica no que tange os produtos patenteados, enquanto o mercado dos genéricos é dominado pelas economias de escalas com uso massivo da distribuição com até três níveis.

Indústria de Máquinas - Por se tratar do tópico principal da presente pesquisa, as colocações acerca do setor, do ambiente institucional e organizacional, e da transação entre a indústria de máquinas e do cafeicultor são realizadas conjuntamente no próximo capítulo. Esta decisão visa facilitar a compreensão do leitor sobre os detalhes que cercam esse relacionamento.

Produção Agrícola - A cafeicultura do Brasil é reconhecida pela sua liderança mundial na produção e exportação do grão, produzindo o dobro do segundo colocado, o Vietnã (MAPA, 2016a). O parque produtivo brasileiro é apresentado na Tabela 1, o qual expõe a relevância da espécie arábica sobre a robusta e justifica o direcionamento da presente análise na colheita mecanizada do café arábica, que também é feito pelo aspecto de qualidade mais frequente dessa espécie.

Tabela 1 - Parque produtivo do café no Brasil (2012-2016)

\begin{tabular}{cccccc}
\hline \multicolumn{5}{c}{ Café Arábica } \\
\hline $\begin{array}{c}\text { Produção } \\
\text { (em mil sacas) }\end{array}$ & $38.344,0$ & $38.285,8$ & $32.305,7$ & $32.048,5$ & $43.382,2$ \\
$\begin{array}{c}\text { Área } \\
\text { (hectares) }\end{array}$ & $1.572 .761,0$ & $1.565 .713,3$ & $1.505 .920,8$ & $1.479 .810,3$ & $1.525 .954,6$ \\
$\begin{array}{c}\text { Produtividade } \\
\text { (sacas/ha) }\end{array}$ & 24,38 & 24,45 & 21,45 & 21,66 & 28,43 \\
Estoque em & 7.721 & 10.714 & 14.163 & 12.983 & 12.470 \\
\hline
\end{tabular}




\begin{tabular}{cccccc}
\hline $\begin{array}{c}\text { armazéns } \\
\text { privados } \\
\text { (em toneladas) }\end{array}$ & 96.876 & 97.116 & 97.133 & 94.382 & 40.820 \\
$\begin{array}{c}\text { Estoque em } \\
\text { armazéns } \\
\text { públicos } \\
\text { (em } \\
\text { toneladas)* }\end{array}$ & $\mathbf{2 0 1 2}$ & $\mathbf{2 0 1 3}$ & & \\
\hline \multicolumn{5}{c}{ Café Robusta } \\
\hline $\begin{array}{c}\text { Produção } \\
\text { (em mil sacas) }\end{array}$ & $12.482,4$ & $10.865,8$ & $13.036,2$ & $11.186,7$ & $7.987,0$ \\
$\begin{array}{c}\text { Área } \\
\text { (hectares) }\end{array}$ & $476.913,0$ & $450.711,9$ & $441.279,0$ & $442.264,0$ & $424.723,0$ \\
$\begin{array}{c}\text { Produtividade } \\
\text { (sacas/ha) }\end{array}$ & 26,17 & 24,11 & 29,54 & 25,29 & 18,81 \\
\hline $\begin{array}{c}\text { Estoque em } \\
\text { armazéns } \\
\text { privados } \\
\text { (em toneladas) }\end{array}$ & 693 & 1.118 & 1.054 & 1.386 & 1.119 \\
\hline
\end{tabular}

*Os dados sobre o estoque em armazéns públicos representam o café arábica e o café robusta.

Fonte: Elaborado pelo autor com base em MAPA (2016c).

O MAPA (2016c) aponta que os principais responsáveis pela produção, em ordem decrescente da quantidade produzida, são os estados de Minas Gerais (MG), São Paulo (SP), Bahia (BA), Espírito Santo (ES) e Rondônia (RO). Nos três primeiros predomina a espécie arábica. O estado de Minas Gerais pode ser dividido em quatro regiões com características diferenciadas; o Cerrado Mineiro, a Chapada de Minas, o Sul de Minas e Região das Matas Mineiras. Já ES e RO são reconhecidos principalmente pela produção do café robusta (Tabela 2).

Tabela 2 - Produção de Café no Brasil em 2016

\begin{tabular}{ccccccc}
\hline \multicolumn{3}{c}{ Arábica } & & \multicolumn{3}{c}{ Robusta } \\
\hline & $\begin{array}{c}\text { Produção } \\
\text { (em mil } \\
\text { sacas) }\end{array}$ & $\begin{array}{c}\text { Área } \\
\text { (hectares) }\end{array}$ & $\begin{array}{c}\text { Produtivi- } \\
\text { dade } \\
\text { (sacas/ha) }\end{array}$ & $\begin{array}{c}\text { Produção } \\
\text { (em mil } \\
\text { sacas) }\end{array}$ & $\begin{array}{c}\text { Área } \\
\text { (hectares) }\end{array}$ & $\begin{array}{c}\text { Produtivi- } \\
\text { dade } \\
\text { (sacas/ha) }\end{array}$ \\
$\begin{array}{c}\text { Minas } \\
\text { Gerais } \\
\text { (MG) }\end{array}$ & $21.965,70$ & $955.497,00$ & 22,99 & 337,20 & $13.375,00$ & 25,21 \\
$\begin{array}{c}\text { São } \\
\text { Paulo } \\
\text { (SP) }\end{array}$ & $4.063,90$ & $198.971,30$ & 20,42 & - & - & - \\
$\begin{array}{c}\text { Espírito } \\
\text { Santo }\end{array}$ & $2.939,00$ & $150.118,00$ & 19,58 & $7.761,00$ & $283.124,00$ & 27,41 \\
\hline
\end{tabular}




\begin{tabular}{ccccccc}
\hline (ES) & & & & & & \\
$\begin{array}{c}\text { Bahia } \\
\text { (BA) }\end{array}$ & $1.162,10$ & $103.450,00$ & 11,23 & $1.183,60$ & $35.228,00$ & 33,60 \\
$\begin{array}{c}\text { Rondônia } \\
\text { (RO) }\end{array}$ & - & - & - & $1.723,90$ & $87.657,00$ & 19,67 \\
\hline
\end{tabular}

Fonte: Elaborado pelo autor com base em Mapa (2016c).

Contudo, as regiões do Brasil são marcadas por diferenças nos processos produtivos.

O Quadro 4 expõem as diferenças e similaridades da produção de cada local. 
Quadro 4 - Características predominantes das Regiões Produtoras de Café no Brasil

\begin{tabular}{|c|c|c|c|c|c|}
\hline Região & $\begin{array}{c}\text { Tipologia de mão } \\
\text { de obra }\end{array}$ & $\begin{array}{c}\text { Porte das } \\
\text { Propriedades }\end{array}$ & Topografia & $\begin{array}{l}\text { Altitude } \\
\text { Média } \\
\text { (metros) }\end{array}$ & Principais agentes do Ambiente Organizacional \\
\hline $\begin{array}{l}\text { Cerrado } \\
\text { Mineiro }\end{array}$ & $\begin{array}{c}\text { Elevada } \\
\text { mecanização } \\
\text { agrícola }\end{array}$ & $\begin{array}{c}\text { Médio a } \\
\text { grande porte }\end{array}$ & Planalto & 800 a 1000 & Federação dos Cafeicultores do Cerrado \\
\hline $\begin{array}{l}\text { Chapada de } \\
\text { Minas }\end{array}$ & $\begin{array}{l}\text { Elevado potencial } \\
\text { para mecanização }\end{array}$ & Grande porte & $\begin{array}{l}\text { Plano e com } \\
\text { presença de } \\
\text { rios }\end{array}$ & 700 & Cooperativa Minas Sul \\
\hline Sul de Minas & Semimecanizada & $\begin{array}{l}\text { Pequeno a } \\
\text { médio porte }\end{array}$ & Montanhoso & 850 a 1250 & $\begin{array}{l}\text { Associação dos Produtores de Café da Mantiqueira } \\
\text { (APROCAM); Associação Brasileira } \\
\text { de Cafés Especiais (ABSC); Cooperativa dos } \\
\text { Cafeicultores da Zona de Três Pontas } \\
\text { (COCATREL); Cooperativa Regional de } \\
\text { Cafeicultores em Guaxupé Ltda (Cooxupé) }\end{array}$ \\
\hline Matas de Minas & Manual & $\begin{array}{l}\text { Pequeno } \\
\text { porte }\end{array}$ & Acidentada & 400 a 1100 & Conselho das Entidades do Café das Matas de Minas \\
\hline São Paulo & $\begin{array}{c}\text { Mecanizada e } \\
\text { Semimecanizada }\end{array}$ & $\begin{array}{l}\text { Pequeno, } \\
\text { médio e } \\
\text { grande porte }\end{array}$ & $\begin{array}{c}\text { Planalto e } \\
\text { Montanhoso }\end{array}$ & 800 a 1000 & $\begin{array}{l}\text { Associação dos Produtores de Cafés Especiais } \\
\text { da Alta Mogiana; Cooperativa de Cafeicultores e } \\
\text { Agropecuaristas (Cocapec); Cooperativa dos } \\
\text { Cafeicultores da Região de Pinhal (Coopinhal) }\end{array}$ \\
\hline Bahia & $\begin{array}{l}\text { Mecanizada; } \\
\text { Semimecanizada e } \\
\text { Manual }\end{array}$ & $\begin{array}{l}\text { Pequeno, } \\
\text { médio e } \\
\text { grande porte }\end{array}$ & $\begin{array}{l}\text { Planalto, Plano } \\
\text { e com rios; e } \\
\text { Montanhoso }\end{array}$ & 850 & $\begin{array}{c}\text { Associação dos Produtores de Café da Bahia } \\
\text { (Assocafé); Associação dos Cafeicultores do Oeste } \\
\text { da Bahia (Abacafé); Cooperativa Mista } \\
\text { Agropecuária Conquistense (COOPMAC); } \\
\text { Cooperativa Agropecuária do Oeste da Bahia } \\
\text { (COOPROESTE) }\end{array}$ \\
\hline
\end{tabular}




\begin{tabular}{|c|c|c|c|c|c|}
\hline Espírito Santo & $\begin{array}{c}\text { Mecanizada e } \\
\text { Semimecanizada }\end{array}$ & $\begin{array}{l}\text { Pequeno, } \\
\text { médio e } \\
\text { grande porte }\end{array}$ & $\begin{array}{l}\text { Planalto e } \\
\text { Acidentado }\end{array}$ & 700 a 1000 & $\begin{array}{c}\text { Cooperativa Agrária dos Cafeicultores de São } \\
\text { Gabriel (Cooabriel) }\end{array}$ \\
\hline Rondônia & Semimecanizada & $\begin{array}{l}\text { Pequeno } \\
\text { porte }\end{array}$ & $\begin{array}{c}\text { Pouco } \\
\text { Acidentado }\end{array}$ & 100 a 600 & $\begin{array}{c}\text { Associação dos Proprietários Rurais (APRRO); } \\
\text { Associação Rural de Jaci-Paraná (ARJAP); } \\
\text { Associação de Produtores Alternativos (APA); } \\
\text { Cooperativa de Produtores Rurais Organizados Para } \\
\text { Ajuda Mútua (COOCARAM). }\end{array}$ \\
\hline
\end{tabular}

Fonte: Elaborado pelo autor. 
Minas Gerais apresenta microrregiões com características bem definidas. O Cerrado Mineiro é caracterizado por um ambiente com elevada mecanização agrícola, propriedades de médio e grande porte e topografia de planalto. A altitude da região varia entre 800 a 1000 metros e apresenta verões úmidos e invernos secos.

A Chapada de Minas é uma região com relevo plano. De modo geral, o território é marcado pela produção de café em grandes propriedades, porém a participação de pequenos cafeicultores vem se desenvolvendo com impacto nas economias locais.

O Sul de Minas apresenta topografia de montanha e um sistema semimecanizado de operações. As propriedades da região são de pequeno e médio porte em sua maioria, porém representam um percentual expressivo na produção brasileira de café.

A Região das Matas de Minas, tal como o sul do estado, se caracteriza por um relevo acidentado que dificulta a entrada de maquinários. As propriedades são caracterizadas por gestão familiar e/ou de pequeno porte, onde a atividade cafeeira torna-se importante opção agrícola rentável. Os agentes produtores dessa área do estado iniciaram a busca pelo registro de marca para reconhecimento de origem, além da tomada de um movimento que visa dar destaque ao tipo de mão de obra utilizado nas lavouras das Matas, valorizando o perfil artesanal da produção.

Os estados de São Paulo e Bahia replicam os três cenários encontrados na região mineira - perfis de propriedade, grau de mecanização, relevos diferentes. São Paulo tem longo histórico da produção do café no Brasil, pois liderou a produção desde o final do período de Império, até então a principal atividade de exportação no Brasil. A região paulista possui condições climáticas favoráveis à produção de café, visto que apresenta temperaturas amenas e altitudes médias variando entre 800 a 1000 metros. A Bahia, que iniciou a produção cafeeira em 1970, conta com uma altitude média de 850 metros nos terrenos com cafezais e temperaturas elevadas.

Assim como SP e BA, o estado do Espírito Santo (ES) apresenta características diversificadas no que tange ao tamanho das propriedades, relevo e condições climáticas. ES é produtor principalmente do café robusta e se sobressaiu como pioneiro na adaptação de máquinas para mecanizar atividade da colheita desta espécie. Já Rondônia (RO) planta exclusivamente essa variedade e apresenta produção cafeeira em pequena escala, com uso majoritário de mão de obra familiar e com colheita semimecanizada.

Atividade de armazenamento - Por ser uma cultura anual com a colheita concentrada em poucos meses, o carregamento de estoques é uma atividade necessária. Essa atividade 
ocorre com a utilização de armazenamento próprio, por empresas terceiras, e em cooperativas. Consequentemente, o produto fica armazenado até a retirada para venda para a indústria, que elaborará a fase de torra e a confecção de blends.

A caracterização desta atividade é feita pela presença de 425 armazenadores registrados (20 públicos, 297 privados, 108 cooperativas), sendo que esses armazéns detêm 1,1 milhão de toneladas de grãos de café arábica. A concentração de armazenamento dos grãos ocorre principalmente nos estados de maior produção: Minas Gerais com 239 estabelecimentos e 883 mil toneladas, São Paulo com 60 armazéns e 105 mil toneladas e o Espírito Santo com 40 galpões e 42 mil toneladas, segundo IBGE (2014a).

Indústria de processamento e beneficiamento - Esta indústria é pulverizada em todo o território nacional com a presença de 406 firmas e com concentração de $73 \%$ de sua produção em 09 principais players $^{11}$, segundo a Associação Brasileira da Indústria de Café (ABIC, 2015).

A indústria de torrefação e moagem de café é responsável pela produção de bens e serviços na escala de R \$ 6,30 bilhões e R \$ 5,02 bilhões em vendas, além de R 1,97 bilhão em produção e R $\$ 1,35$ bilhão em vendas para o setor de fabricação de produtos à base de café (ex. café solúvel) (IBGE, 2014b).

A produção do setor é estruturada como um oligopólio com franja competitiva em virtude da concentração das atividades industriais das nove empresas líderes, em ordem decrescente: Grupo Três Corações, Jacobs Douwe Egberts (marcas Pilão, Café do Ponto e Caboclo), Indústria de Alimentos Maratá, Melitta, Mitsui Alimentos, Companhia Cacique de Café Solúvel, Café Bom Dia, São Braz S/A Indústria e Comércio de Alimentos e Café Pacaembu.

Quanto às tecnologias, observa-se a similaridade entre as líderes de mercado. A diferenciação tecnológica aparece majoritariamente em situações de mudança de produto, isto é, equipamentos para produção de café em pó, cápsulas ou grão torrado. O retrato desse exposto é tido pelo amadurecimento das inovações no setor, visto que as novas alterações estão direcionadas quase exclusivamente para o mercado do café em monodoses, como cápsulas, sachês e expressos. Consequentemente, a formação dos preços de venda para o

\footnotetext{
${ }^{11}$ Ainda, as cooperativas aparecem como outros agentes relevantes do setor, contudo a carência de informações sobre a capacidade produtiva, do processamento e torrefação dessas organizações impede a análise aprofundada com este enfoque, sendo relevante apenas um apontamento. A dinâmica das cooperativas difere da das empresas em pontos como a assistência técnica oferecida aos cooperados, serviços de crédito, insumos, seguro contra roubos, transporte, armazenamento e outros, os quais são observados como fatores de estreitamento na relação do cafeicultor com a cooperativa, ou seja, facilitam as negociações entre ambos.
} 
consumidor final é afetada por três fatores: tipo do produto final (café solúvel, cápsula, etc.), a marca da torrefadora e a qualidade do produto.

As empresas com interesse no mercado de cafés de alta qualidade, como a torrefadora italiana illycaffè, negociam preços com base em parâmetros de preço internacionais, localização do cafeicultor e atributos de qualidade do grão.

Indústria de solúvel - Este setor é responsável pelo processamento de $10 \%$ da safra anual de café no Brasil, sendo $80 \%$ de produção suprida pelo café robusta (Associação Brasileira da Indústria de Café Solúvel, [ABICS], 2017a). A indústria contém a concentração de $90 \%$ de sua exportação em 05 empresas. A concentração de exportação pode ser considerada análoga a concentração de produção, pois as firmas desse segmento são voltadas à exportação, a qual é responsável por uma parcela considerável dos seus faturamentos (Neves, 2009).

O setor é responsável pela participação de $11 \%$ nas exportações de café do Brasil com 3,8 milhões de sacas e geração de receita de cerca de US\$ 596 mil em 2016 (ABICS, 2017b). Ainda de acordo com este relatório, o café solúvel embalado para consumo direto é responsável por aproximadamente $41 \%$ desse mercado. Enquanto os outros $59 \%$ é direcionado a venda à granel para auto-atendimento de máquinas de café solúvel ou outros bebidas cafeinadas, blends com marcas de varejistas, entre outras (Neves, 2009).

Ainda de acordo este autor, assim como no caso da indústria de café torrado, as líderes desse mercado possuem as mesmas tecnologias. As etapas de processamento como, por exemplo, cozimento do café torrado, concentração e secagem do extrato do café são procedimentos que exigem equipamentos especializados, mas o acesso a tais tecnologias já é difundido entre as firmas do setor.

A diferenciação do produto se dá pela principal matéria-prima, o café verde. A depender da qualidade do grão, há maior qualidade do café solúvel. Portanto, a formação de preço ocorre pelos dois fatores, a marca e a qualidade do café verde utilizado na industrialização. A qualidade do insumo é feita principalmente pelo sistema de classificação brasileiro que avalia os defeitos da bebida a partir do grão, a pureza, o sabor, a cor, a peneira. ${ }^{12}$ (Neves, 2009).

Esse mercado se diferencia do mercado de café torrado pelo tipo de café predominante. Aqui há maior processamento de café robusta. Enquanto no outro setor há maior participação do café arábica (ABICS, 2017a).

\footnotetext{
${ }^{12}$ Para maiores detalhes, ver (MAPA, 2003b).
} 
Distribuição - As redes de supermercados, hipermercados e atacadistas são dispersas ao longo do território brasileiro. A maior expressividade quanto a faturamento é da região Sudeste com 37\% (Associação Brasileira de Atacadistas e Distribuidores [ABAD], 2015). A concentração de empresas desse setor é maior na região Nordeste com 193, seguido do Centro-Oeste (99), Sudeste (87), Sul (84), Norte (81). ABAD (2015) apresenta a informação de que as firmas líderes do setor no Estado de SP aparecem com faturamento de R\$ 7,75 bilhões, em MG com R \$ 4,5 bilhões, na BA com R\$ 900 milhões, no ES com R\$ 850 milhões, e em RO com R\$ 600 milhões. As posições dessas firmas no ranking de classificação geral de todo o Brasil são $1^{\circ}, 2^{\circ}, 12^{\circ}, 15^{\circ}$ e $22^{\circ}$ lugar, respectivamente.

De acordo com Instituto Brasileiro de Executivos de Varejo e Mercado de Consumo (IBEVAR, 2015), o setor varejista é dominado por três grupos: Pão de Açúcar, Carrefour e Walmart. O trio deteve 424 bilhões de reais, equivalente a $31 \%$ do consumo de bens e serviços do país em 2014. O ranking aponta que as dez principais empresas varejistas representam mais que $50 \%$ do segmento. Dessa forma, pode-se observar a estrutura de mercado de oligopólio nas categorias de supermercados, hipermercados e atacadistas.

A diferenciação tecnológica do setor ocorre timidamente. As inovações são presentes, embora o padrão das tecnologias seja vastamente conhecido até entre os pequenos players, como por exemplo, sistemas de tecnologia da informação para gerenciamento de estoque, comunicação automática com fornecedores, etc. A onda tecnológica encontra-se em processo de incorporação via comércio eletrônico e estruturas de autosserviço, sendo essas estruturas o diferencial das líderes do segmento de distribuição.

A formação de preços do café é um ponto complexo no setor. O preço do produto nas redes de varejo é construído com base na localização e no padrão de consumo na região. $\mathrm{O}$ pagamento para as torrefadoras depende, portanto, do fator geográfico assim como do volume do café comprado e da marca em questão, pois a atual percepção de qualidade pelo consumidor brasileiro de café não é construída paulatinamente por indicadores técnicos, mas sim pela marca da empresa produtora.

A indústria distribuidora inserida no SAG de café pode ser observada por outros estabelecimentos especializados na venda do café como, por exemplo, bares, cafeterias, restaurantes e hotéis, além do café preparado nos domicílios e no trabalho. O levantamento da ABIC (2015) ressalta a existência de 2.500 cafeterias ao longo do território brasileiro, sendo esperada uma variação positiva no surgimento de novos pontos de comercialização na faixa de 20\%, isto é, há expectativa de crescimento (ABIC, 2015). 
E assim como no ambiente dos supermercados, o enfoque de varejo especializado no café possui a mesma lógica quanto à tecnologia e à formação de preço. A tecnologia possui relevância pelos equipamentos utilizados para preparação do café. A estratégia de diferenciação para formação do preço do setor se pauta na prestação de serviços, especificamente, no atendimento e nas marcas comercializadas.

Os preços caminham na mesma direção seguida pelos hipermercados e atacadistas. A definição de valor dos estabelecimentos especializados pelo consumidor é pautada na localização, público-alvo, qualidade dos grãos de cafés utilizados na bebida e na marca da empresa.

Consumo - Por meio da Tabela 3, observa-se o aumento do consumo do café, tanto o torrado e moído, quanto o solúvel e o verde no território brasileiro.

Tabela 3 - Comparativo do consumo do café no Brasil (1993 e 2015)

19932015

\begin{tabular}{cccc}
\hline Café solúvel (consumo per capita: $\mathbf{k g} / \mathbf{h a b i t a n t e} / \mathbf{a n o})$ & 2,67 & 6,02 \\
Café verde (consumo per capita: $\mathbf{k g} / \mathbf{h a b i t a n t e / a n o )}$ & 3,62 & 6,12 \\
Café torrado (consumo per capita: $\mathbf{k g} / \mathbf{h a b i t a n t e / a n o )}$ & 2,89 & 4,90 \\
\hline
\end{tabular}

Fonte: Elaborado pelo autor com base em ABIC (2015).

De acordo com ABIC (2015), as regiões com maior índice de crescimento quanto ao consumo dentro dos lares, em 2014, foram: Sul (8,8\%), Norte $(9,1 \%)$ e Centro-Oeste $(7,8 \%)$.

Outro apontamento é a presença desse produto na cesta de consumo da família brasileira, especificamente, em 98\% dos lares do Brasil (IBGE, 2009). A cultura de consumo do café já está enraizada e o café é tido como um produto com caráter de necessidade básica na alimentação. O maior consumo médio diário per capita no Brasil é liderado pelo café com 215,1g/dia, denotando a importância desta bebida, conforme IBGE (2009). Os dados dessa pesquisa demonstram a concentração de maior consumo per capita (g/dia) nas regiões Nordeste $(230,4)$, Sudeste $(215,2)$, Sul $(220,1)$; em contrapartida, as regiões com menor consumo são Norte $(195,1)$ e Centro-Oeste $(167,8)$. O maior consumo do café fora do domicílio, em níveis percentuais da relação com o consumo total, é observado nas regiões Sudeste (12,5\%) e Centro-Oeste (11,9\%).

Os estados de São Paulo e Minas Gerais têm representatividade no consumo de produtos e derivados do café, sendo responsáveis, respectivamente, pela absorção de 
aproximadamente R 2,35 bilhões e $\mathrm{R} \$ 500$ milhões nas vendas de café torrado e moído (IBGE, 2010).

Quanto ao mercado externo, nota-se a variação da receita gerada e do volume exportados nas quatro categorias de café (verde, solúvel, torrado e moído e outros concentrados) durante os últimos cinco anos (Tabela 4).

Tabela 4 - Receita e volume das exportações de café (2012-2016)

\begin{tabular}{cccccc}
\hline $\begin{array}{c}\text { Receita gerada } \\
\text { (em mil U\$) }\end{array}$ & $\mathbf{2 0 1 2}$ & $\mathbf{2 0 1 3}$ & $\mathbf{2 0 1 4}$ & $\mathbf{2 0 1 5}$ & $\mathbf{2 0 1 6}$ \\
\hline Café verde & 5.721 .758 & 4.582 .237 & 6.041 .101 & 5.555 .415 & 4.787 .500 \\
\hline Café solúvel & 698.482 & 649.766 & 563.324 & 556.404 & 596.974 \\
$\begin{array}{c}\text { Café torrado e } \\
\text { moído }\end{array}$ & 18.376 & 15.861 & 11.603 & 10.079 & 11.634 \\
$\begin{array}{c}\text { Outros extratos e } \\
\text { concentrados do } \\
\text { café }\end{array}$ & 23.853 & 27.852 & 45.830 & 36.754 & - \\
\hline $\begin{array}{c}\text { Volume } \\
\text { exportado (sacas) }\end{array}$ & $\mathbf{2 0 1 2}$ & $\mathbf{2 0 1 3}$ & $\mathbf{2 0 1 4}$ & $\mathbf{2 0 1 5}$ & $\mathbf{2 0 1 6}$ \\
\hline $\begin{array}{c}\text { Café verde } \\
\text { Café solúvel }\end{array}$ & 25.061 .900 & 28.319 .117 & 33.108 .440 & 33.417 .234 & 30.148 .595 \\
\hline $\begin{array}{c}\text { Café torrado e } \\
\text { moído }\end{array}$ & 44.228 & 39.944 & 31.447 & 33.307 & 29.206 \\
$\begin{array}{c}\text { Outros extratos e } \\
\text { concentrados do } \\
\text { café }\end{array}$ & 163.410 & 27.852 & 349.857 & 282.923 & - \\
\hline $\begin{array}{l}\text { Fonte: Elaborado pelo autor com base em MAPA (2016a) e Conselho dos Exportadores de Café do Brasil } \\
\text { (CECAFE, 2016). }\end{array}$ & & & & \\
\hline
\end{tabular}

Ainda no mercado internacional, observou-se que os produtos tiveram as exportações direcionadas a quatro continentes: América do Norte, América do Sul, Europa e Ásia (Tabela $5)$.

Tabela 5 - Resumo dos principais destinos de exportações de café (2015)

\begin{tabular}{cccc}
\hline Produto & País destino & $\begin{array}{c}\text { Receita gerada } \\
\text { (em mil U\$) }\end{array}$ & $\begin{array}{c}\text { Volume exportado } \\
\text { (toneladas) }\end{array}$ \\
\hline \multirow{2}{*}{ Café verde } & União Europeia & $2.678 .199,00$ & 947.531 \\
& Estados Unidos & $1.086 .491,00$ & 400.221 \\
& Japão & 387.973 & 115.339 \\
\hline \multirow{2}{*}{ Café solúvel } & União Europeia & 91.703 & 12.474 \\
& Estados Unidos & 79.691 & 12.607 \\
& Rússia & 59.678 & 8.429 \\
\hline
\end{tabular}




\begin{tabular}{cccc}
\hline \multirow{2}{*}{$\begin{array}{c}\text { Café torrado e } \\
\text { moído }\end{array}$} & Estados Unidos & 3.887 & 481 \\
& União Europeia & 2.002 & 459 \\
& Argentina & 758 & 167 \\
& Japão & 601 & 120 \\
\hline $\begin{array}{c}\text { Outros extratos e } \\
\text { concentrados do }\end{array}$ & Argentina & 12.267 & 3.032 \\
café & Japão & 13.132 & 2.208 \\
\hline
\end{tabular}

Fonte: Elaborado pelo autor com base em MAPA (2016a).

\subsubsection{Análise do Ambiente Institucional}

A atividade das instituições acontece por dois principais pontos. Primeiramente, há a atuação internacional dos países importadores afetada pelos acordos internacionais. $\mathrm{O}$ segundo relaciona-se ao exercício das instituições do sistema judiciário brasileiro (ex: Tribunais, Ministérios Públicos, Procuradorias) com base nas legislações de distintas naturezas, tais como sanitária, ambiental, trabalhista e do consumidor, que afetam o SAG do café.

A indústria de insumos é usualmente fiscalizada pelos aspectos sanitário, ambiental e trabalhista. Já no setor de produção agrícola são notadas as esferas do trabalho e ambiental. Os cafeicultores são autuados principalmente por questões voltadas à terceirização da colheita e problemas trabalhistas, como condições do ambiente e jornada de trabalho, remuneração e tributos, os quais serão aprofundados no Capítulo 5 deste estudo. A fiscalização da esfera ambiental é direcionada ao descumprimento de proteção dos recursos naturais - contaminação de solo, rios e desmatamento de áreas preservadas. Entretanto, ressalta-se que esse cenário passou por transformações, tornando essa realidade quase extinta, ou seja, ele não é o padrão encontrado, mas sim a exceção.

A atuação regulatória na indústria de processamento (torrado e solúvel) e distribuição ocorre predominantemente em quatro áreas. A sanitária, em razão da segurança alimentar; a ambiental, em consequência da preocupação com a poluição por resíduos tóxicos derivados das atividades industriais e logísticas; a trabalhista: é comum ao caso mencionado na produção agrícola; e a legislação de proteção do consumidor, que se dá pelos potenciais conflitos resultantes de assimetrias informacionais, desacordos contratuais de entrega ou preço.

Ambiente Institucional, Acordos Internacionais - A International Coffee Organization (ICO), principal órgão norteador das políticas internacionais do café, é responsável por debater acordos reguladores em nível mundial. A origem dos acordos é 
datada da década de 60 e continuamente renovada até o ano de 2007, com a criação do sétimo deles, ainda vigente. As decisões ao longo dos anos variaram com objetivos de controle da oferta e demanda, controle de preço devido aos problemas climáticos, rigidez em sistemas de rastreabilidade de países exportadores, controle de estoques nacionais, criação de sistemas de informação com banco de dados robustos, fórum de discussões entre as lideranças, criação de espaços para troca de experiência relacionada à sustentabilidade, programas de treinamento e desenvolvimento de tecnologias. O enfoque do acordo internacional (ICO, 2007) visa a direcionamentos quanto à segurança alimentar; desenvolvimento local de pequenas comunidades, além de uma aproximação cada vez maior entre os governos dos países membros.

\subsubsection{Análise do Ambiente Organizacional}

O desempenho das organizações no SAG do café aparece por meio de diferentes objetivos. A presente dissertação enfoca dois: o financeiro e o de ação coletiva. O primeiro atua como facilitador de crédito para as distintas atividades ao longo do sistema produtivo, enquanto o segundo se manifesta como ação coletiva de suporte de prestação de serviços ou poder de barganha para a produção agrícola.

Ambiente Organizacional, Instituições Financeiras - A obtenção de crédito agrícola se concentra em 09 principais bancos (Banco Central do Brasil [BCB], 2013). A atuação desses agentes é relevante pela necessidade de investimentos nas atividades agrícolas, fabris, de distribuição e de comercialização.

Outros bancos voltados especialmente para o agronegócio merecem ser citados. O setor bancário com este enfoque pode ser exemplificado pelos seguintes grupos: Sistema de Cooperativas de Crédito do Brasil (Sicoob), o Banco Original do grupo JBS, Fibra, e o Rabobank, sendo este último uma das organizações mais relevantes para o agronegócio no Brasil e no mundo.

A operacionalização do crédito dessas instituições financeiras, especificamente para o agronegócio do café, é direcionada à produção agrícola por meio do Fundo de Defesa da Economia Cafeeira (Funcafé). A linha de financiamento envolve recursos para financiar o custeio, a colheita, a estocagem e a comercialização de lavouras cafeeiras por meio de recursos oriundos do Tesouro Nacional, além de fins de pesquisa e desenvolvimento industrial. O programa se destina a cafeicultores, cooperativas e agroindústrias do setor de 
café com a seguinte divisão de orçamento para o ano de 2016: até R\$ 1 bilhão para financiamento de aquisição de café; até R\$ 950 milhões para operações de custeio; até R \$ 1,752 bilhão para operações de estocagem; até R \$ 10 milhões para financiamento de contratos de opções e de operações de mercados futuros; R \$ 200 milhões para capital de giro nas indústrias de café solúvel; até R\$ 300 milhões para capital de giro das indústrias de torrefação; até R\$ 400 milhões para cooperativas de produção; R\$ 20 milhões para recuperação de cafezais $(\mathrm{BCB}, 2016)$.

Outro destaque da atuação é a do Banco Central, pelo Programa de Garantia da Atividade Agropecuária (Proagro), o qual exonera o produtor de débitos de financiamentos agropecuários frente à ocorrência de frustração de safra, seja por eventos adversos de natureza climática ou biológica. Ou seja, trata-se de sistema de seguro rural.

Já com enfoque na colheita, surgem os recursos financeiros para mecanização agrícola das linhas de crédito do Banco Nacional de Desenvolvimento Econômico e Social (BNDES). Especificamente como objetivo da pesquisa, a possibilidade de mecanização na colheita de cafezais pelos empréstimos dos programas Finame Agrícola e Moderfrota são aprofundados na Seção 5 com o intuito de ampliar os detalhes acerca desse objeto.

Ambiente Organizacional, Associações de produtores - As associações de produtores de café emergem principalmente para compartilhamento de equipamentos e aumento do poder de barganha.

A partilha de recursos entre associados ocorre usualmente em grupos cujos associados são pequenos produtores que almejam a mecanização da colheita. Os associados buscam a coletividade como uma forma mais viável de obtenção do investimento necessário para compra de máquinas. Posteriormente à compra, o grupo associado realiza escalas de uso do recurso coletivo e responsabilidades sobre ele, assim como nas práticas adotadas em algumas cooperativas.

Já o poder de barganha aparece por duas lentes. Uma é relacionada à possibilidade de aumentar o poder nas negociações de pequenos produtores. A outra transparece pelo aspecto de qualidade, isto é, cafeicultores com grãos diferenciados que necessitam de visibilidade para negociar com as torrefadoras interessadas neste nicho de mercado como, por exemplo, o caso dos associados da Brazil Specialty Coffee Association.

Ambiente Organizacional, Cooperativas - As cooperativas como organização de apoio aparecem com o foco na prestação de serviços. A ação coletiva oferece suporte de 
diferentes naturezas aos cafeicultores. A organização fornece auxílio para obtenção de serviços ou até mesmo do produto em si, como, por exemplo, fertilizantes, produtos de sanidade vegetal, máquinas e implementos agrícolas, assistência técnica e crédito diferenciado. Um movimento recente na cafeicultura é a aproximação das cooperativas em relação aos produtores inovadores. Um exemplo são os cafeicultores realizando a adaptação em máquinas para tornar a colheita mecanizada possível em seus cafezais, ou seja, ajustes de altura e inclinação para terrenos acidentados, alterações em motocicletas para aplicação de agrotóxicos em corredores estreitos, entre outros.

Assim como no caso das associações, nota-se a presença de cooperativas com atuação local ou nacional, bem como exportação.

\subsubsection{Análise das Transações}

Nesta subseção serão analisadas as principais transações do SAG do café brasileiro (Figura 3), tendo o cafeicultor como enfoque principal. Essa parte da investigação enfoca as estruturas de governança com base na Figura 2 e compara-as aos estudos de Zylbersztajn et al. (1993) e Saes e Farina (1999).

Cafeicultor e Indústria de Mudas (T1) - A governança esperada para esta transação são os mecanismos de coordenação via mercado, pois a frequência não é elevada, e a incerteza e a especificidade de ativos são presentes, embora com um nível que não implica a estrutura de governança para arranjos institucionais mais coordenados.

A transação do cafeicultor com a indústria de mudas era conduzida predominante por cooperativas e pela integração vertical (Zylbersztajn et al., 1993). Os produtores compravam as mudas diretamente da cooperativa, já que a entidade era capaz de minimizar os custos de produção das mudas por meio da assistência técnica e novas tecnologias advindas de entidades de pesquisa públicas, como no caso da relação do IAC com a COOPEMAR, ainda presente com seus viveiros. Já na produção integrada verticalmente, notou-se o caso dos produtores do Espírito Santo com o sistema de reprodução vegetativa por estaquia na década de 90 .

A transação do cafeicultor com a indústria de mudas mostra diversos mecanismos de coordenação. A produção é realizada por empresas especializadas na comercialização de mudas e pela produção independente em propriedades rurais. Ressalta-que a compra de mudas ocorre pelo mercado spot, contratos de fornecimento regular, venda via cooperativa, produção própria (integração vertical) e mercado informal (ausência de registro dentro do MAPA), ou 
seja, as relações observadas em Zylbersztajn et al. (1993) ainda são presentes, mas a representatividade na produção de mudas passou a ser dominada por empresas especializadas devido ao acúmulo de conhecimento técnico sobre as variedades cafeeiras, ou pela minimização de custos logísticos no transporte para os cafezais por meio da atuação local dessas firmas. Posto isso, faz-se necessário o apontamento das características de frequência, incerteza e especificidade da transação.

A transação não é frequente, visto que os cafezais são considerados como uma lavoura permanente com duração média de idade de 15 a 20 anos, isto é, a negociação entre os agentes ocorre no momento inicial da plantação dos primeiros cafezais, em períodos de expansão produtiva ou manutenção das lavouras.

A incerteza envolvida na transação é baixa. A presença dessa característica se dá pelas mudanças das tecnologias genéticas. O melhoramento das mudas é feito por instituições de pesquisa que buscam facilitar o acesso ao novo material genético pelos produtores quando um novo produto é criado.

Quanto à especificidade de ativos, existem investimentos específicos de natureza física, da genética e das tecnologias inerentes à muda em si. Entretanto, esse aspecto é diretamente associado ao ambiente organizacional do setor. Os investimentos dessa natureza ocorrem por meio de terceiros, como por exemplo, entidades públicas de pesquisa (IAC, EMBRAPA). Tal situação explica a baixa interferência dessa variável na governança, em virtude da pesquisa e do desenvolvimento genético serem assumidos por terceiros e não pelo próprio produtor de mudas.

Cafeicultor e Indústria de Fertilizantes - A coordenação esperada condiz com a realidade da governança via mercado. O relacionamento passou por transformações advindas de fusões ou aquisições de empresas multinacionais de acordo com a abertura comercial da política econômica da época, porém o arranjo institucional via mercado prevaleceu e se solidificou devido ao aumento da concentração dos líderes desse segmento a partir dos anos 90 (Saes \& Farina, 1999).

A transação apresenta frequência recorrente, incerteza relacionada a preços e prazos de entrega e especificidade de ativos físicos e de capital humano. Todavia, a expressividade da especificidade é amenizada pela barreira de entrada de um mercado altamente concentrado, ou seja, mesmo com um nível elevado de especificidade, a produção verticalizada dos fertilizantes é inviável para o produtor rural, visto que não é possibilitado ao agente obter as economias de escala alcançadas na indústria e nas misturadoras. 
A transação com a indústria de fertilizantes é cercada por um ambiente tecnológico complexo. Os produtos possuem peculiaridades, como nos casos dos fertilizantes de liberação lenta, foliares e diferenciados, além do que, assim como na situação referente aos defensivos, há um cuidado quanto aos limites de resíduos químicos para evitar a contaminação de solos e de lençóis freáticos.

A frequência de negociação é anual, pois o produtor prefere não carregar estoques. A aplicação dos fertilizantes pode ocorrer semanalmente ou entre meses, a depender do sistema produtivo do cafeicultor e das variedades plantadas. A incerteza de mercado aparece com uma magnitude pouco impactante: sua existência influencia pouco a transação, pois os preços sofrem interferências de questões macroeconômicas como câmbio, tarifas, despesas portuárias. O preço final para o cafeicultor é alterado constantemente, mas em pequenas parcelas. A incerteza institucional é quase imperceptível, contudo a tecnológica é relevante. No cenário cafeeiro é observada a existência de diversos encontros e eventos que buscam capacitar os produtores quanto ao uso correto de fertilizantes. A tecnologia de micronutrientes e/ou produtos granulados é um tema confuso para esse público, assim como a própria aplicação - no solo ou na folha. Tais assuntos são recorrentes e tidos como fontes de dúvidas, visto que a dinamicidade de novos produtos é elevada.

A especificidade locacional é visualizada por dois pontos. O primeiro pelos investimentos necessários para transporte em virtude do volume do produto, sendo ele intrínseco ao preço quando a responsabilidade de entrega recai sobre o vendedor, pois o uso de fertilizantes pode chegar a volumes consideráveis de aplicação a depender do tamanho do cafezal. E o segundo, é o fator de localização referente aos insumos. A produção de fertilizantes exige proximidade com as fontes mineiras de matéria-prima para diminuição de gastos com o transporte do material até a planta industrial, visto que esse transporte é tão volumoso quanto a escala de compra do produto final, ou até maior.

Destaca-se neste recorte o papel dos canais de comercialização. A compra dos fertilizantes ocorre por revendas e usualmente por cooperativas. Essa estrutura de distribuição é necessária em virtude da natureza do setor. A compra de insumos para produção de fertilizantes exige estrutura de capital ampla, isto é, firma com capacidade de gerar escala e diminuir custos de estoque.

As cooperativas, além de obter as vantagens de economia de escala, equilibram eventual poder de monopólio da indústria de fertilizantes mais concentrada. A utilização dos fertilizantes ocorre na escala de toneladas, logo, os próprios custos logísticos e de armazenamento podem ser mitigados com a utilização de compra em escala. A gestão de 
aquisição para grandes grupos de cooperados minimiza a perda de capital na relação de necessidade de estoque e altos juros, além de afetar diretamente o valor pago à indústria de insumos. Assim, a cooperativa garante a diluição dos custos de obtenção dos fertilizantes.

Outra função da organização é o aumento do poder de barganha, conforme já mencionado anteriormente. Como consequência da concentração dos produtores de fertilizantes, a indústria consegue impor o preço e faz com que o produtor rural se torne um tomador de preço em cenários de compras individuais. Portanto, a estrutura da cooperativa visa ao equilíbrio do poder nas negociações entre ambos os agentes.

Cafeicultor e Indústria de Defensivos - A estrutura de governança esperada da transação entre produtores de café e a indústria de defensivos é a relação de mercado pelas revendas e/ou cooperativas, que predominam como canal de distribuição desde o final do século XX (Saes \& Farina, 1999).

O cenário da transação é similar ao do relacionamento com a indústria de fertilizantes. A frequência é baixa, visto que os agentes de menor porte evitam arcar com os custos de estoque. A incerteza é pouco presente, pois os fatores tecnológicos são complexos para o produtor agrícola, porém as especificações técnicas da tecnologia do produto são informadas com o apoio de cooperativas, ou pela assistência técnica das revendedoras ou das próprias empresas fabricantes. Já a especificidade do ativo é alta. Os defensivos sugerem especialização a partir das inovações biotecnológicas, além dos investimentos em pesquisa e desenvolvimento com base no capital humano.

A forma de coordenação da transação é imposta pela indústria de defensivos, de certa forma, pelos mesmos pontos da indústria de fertilizantes, isto é, uma estrutura de mercado altamente concentrada por empresas multinacionais que conseguem impor suas regras, já que a produção dos defensivos agrícolas depende de fatores macroeconômicos quase que intransponíveis para pequenos produtores, como, por exemplo, aquisição de insumos em grandes volumes via importação, altos investimentos em pesquisa e desenvolvimento, custos tarifários, custos logísticos, entre outros.

As revendas e cooperativas se destacam. A distribuição por esses canais acompanha a lógica das economias de escala, os custos de estoque e a dificuldade de negociações com um ambiente industrial de alta concentração. A existência desses canais de comercialização se explica como no caso dos fertilizantes. 
Cafeicultor e Indústria de Processamento - Com base em Zylbersztajn et al. (1993) e Saes e Farina (1999), observa-se que algumas transações passaram por mudanças, as quais são expostas pontualmente em cada caso.

(1) A forma básica de relacionamento entre o cafeicultor e torrefadores ocorre por meio do mercado spot. Usualmente, essa forma de governança é permeada por intermediários, como corretores e cooperativas. A transação envolve produto de baixa qualidade, sendo os incentivos financeiros quase que inexistentes e, portanto, é possível observar o cafeicultor agindo como um especulador de mercado e utilizando as flutuações de preço para negociações. Logo, a especificidade de ativos é considerada praticamente inexistente, assim como a atuação pouco impactante das características de incerteza e frequência.

(2) Outro mecanismo de coordenação é o uso de contratos futuros. Essa ferramenta ocorre quando há a intenção de travar preços frente a uma incerteza mercadológica. A especificidade neste caso não é muito relevante, pois o produto negociado é tido como commodity. E ainda, a frequência é de difícil avaliação, já que a recorrência dessa forma de comercialização varia de acordo com as peculiaridades, como por exemplo, o perfil de risco de cada produtor.

Neste caso, há um aumento do uso dos contratos a termo para controle de preços devido à volatilidade do mercado do café, ferramenta recente e pouco difundida no período avaliado por Zylbersztajn et al. (1993) e Saes e Farina (1999).

(3) Alguns traços peculiares ascendem nas etapas de processamento de póscolheita, que pode ser feito na propriedade ou até ser parcialmente contratado. Há cafeicultores que realizam processos como separação via peneira, secagem na própria propriedade. Aparecem situações de contratação de mão de obra terceirizada para essas atividades para posterior comercialização do fruto "pré-beneficiado". Ou seja, diversas ações pré-porteira podem ser realizadas por meio de prestação de serviços de empresas especializadas ou via contratação de mão de obra pelo cafeicultor para posterior venda. E ainda, tais ações se repetem no processo de beneficiamento. O produtor utiliza beneficiadoras para depois comercialização com uma indústria de torrefação. Logo, internaliza os equipamentos responsáveis por esses processos ou adota a prestação de serviço de beneficiamento por uma firma especializada. 
Portanto, é possível observar os dois fenômenos dentro do SAG de café no Brasil. Ao focalizar diretamente a venda, observa-se o fenômeno de integração vertical da operação de processamento e beneficiamento e parte dessa transação é realizada dentro da propriedade rural. Há um investimento por parte do cafeicultor na aquisição de equipamentos para esse fim, além da contratação de mão de obra. Essa tendência já foi prevista por Zylbersztajn et al. (1993), ou seja, a extinção do maquinista e a incorporação dessas atividades pelo próprio produtor, ou pela terceirização com empresas especializadas nessas atividades - situação em que o produtor fornece o café e a empresa presta o serviço e devolve o café já beneficiado para o cafeicultor, sendo o pagamento realizado em dinheiro ou até mesmo em café. Dessa forma, pode-se caracterizar esse relacionamento como distinto do café commodity. A transação com o grão previamente beneficiado carrega investimentos nos processos produtivos. O uso da especificidade de ativos físico (compra de equipamentos para gerarem o grão despolpado e/ou descascado) no produto acarreta em incerteza de mercado, pois a qualidade do produto é maior e o preço pode induzir falhas informacionais. Além do que, nota-se a existência de diversas técnicas para a realização do pré-beneficiamento, isto é, tecnologias que se alteram constantemente e que carregam a incerteza tecnológica de imprevisibilidade quanto à eficiência desses equipamentos. Essa transação é outro caso que passou por transformações.

(4) Ainda interligado com enfoque de verticalização de transações, há a existência de produtores que internalizam as transações com a indústria de beneficiamento por completo, ou seja, o cafeicultor passa a realizar todo o processo de manufatura industrial. Assim como no caso da (3), este cenário retrata especificidade física em razão da exigência de investimentos para as atividades de beneficiamento, que exigem a alocação de recursos em equipamentos de torrefação. Ademais, a especialização é vista no capital imobilizado nas máquinas e na especificidade humana que a atividade exige.

O controle dos processos industriais dessa atividade demanda mão de obra especifica, em particular na etapa de torrefação. As atividades de moagem e/ou embalagem possuem sua relevância, porém o estágio da torra é que define a qualidade em conjunto com os atributos do grão de café. O conhecimento acerca das características físicas e químicas no beneficiamento do produto e, consequentemente, o capital humano, destacam-se como aspectos significativos.

Dessa forma, a dinâmica desse relacionamento carrega um nível de especificidade e incerteza tecnológica maior em relação ao caso anterior. E, ao mesmo tempo, a sua existência 
reforça o argumento de troca do maquinista por empresas especializadas ou pela própria internalização da transação pelo cafeicultor, conforme já previsto por Zylbersztajn et al. (1993).

(5) Além da internalização das atividades industriais, surgem os cafeicultores que verticalizam os processos de distribuições e constroem as relações diretas com o consumidor final. O fenômeno não é regra. A integração vertical à jusante até a etapa de comercialização é recente no sistema produtivo do café. O retrato pode ser visto por meio de produtores que realizam quase todas as operações da cadeia por meio de uma gestão própria, ou seja, realizam as operações de colheita, pós-colheita, processamento, beneficiamento, distribuição e comercialização em pontos de venda.

Os agentes dessa transação elevam ainda mais o nível de especificidade de ativos. Os investimentos idiossincráticos são realizados no segmento de distribuição, ou seja, há alocação de recursos nos equipamentos de beneficiamento, estruturas de distribuição e, principalmente, na especificidade de marca, outro coadjuvante nesse quadro.

Alguns exemplos dessas particularidades podem ser observados pelas cafeterias em regiões nobres da cidade de São Paulo, como Suplicy e Octavius. As iniciativas passaram a surgir no início do século XXI. Tais estruturas de governança não eram observadas ou previstas no modelo do Sistema Agroindustrial do Café na década de 90 (Zylbersztajn et al., 1993; Saes \& Farina, 1999).

Subsistema de qualidade - Além das peculiaridades quanto à verticalização, surge a governança pelos subsistemas estritamente coordenados com a valorização de atributos de qualidade com incentivos para produção.

(6) Uma mudança no setor de café no Brasil foi a evolução das estratégias com programas de qualidade. O ainda utilizado, mas não exclusivo, Programa Brasileiro de Qualidade de Produtividade (PBQP), em parceria com a Associação Brasileira das Indústrias de Café (ABIC), introduziu ações que visavam ao incremento de qualidade no café brasileiro, como no caso do Programa Permanente de Controle da Pureza do Café em 1989.

O programa é utilizado como um controle para cafés de média a baixa qualidade, porém sua criação gerou inúmeras consequências. Um efeito foi a criação da metodologia de avaliação para o nicho de cafés especiais de empresas privadas, assim como os seus eventos de reconhecimento dos melhores produtores. A última ação chamou a atenção do Estado, haja vista a proximidade entre os responsáveis dessa operação na indústria estar inserida com os 
representantes do Estado para a construção desses eventos, tais como o concurso de melhor cafeicultor de São Paulo, Minas Gerais etc.

Essas situações reforçaram a produção diferenciada com enfoque na qualidade do café não commodity. Dessa forma, a coordenação dessas transações passou a ocorrer de modo particular. Um destaque foi a governança por meio dos subsistemas estritamente coordenados com o controle em posse do agente coordenador, como por exemplo, a torrefadora italiana illycaffe e seu arranjo de coordenação no sistema produtivo de café no Brasil.

A qualidade do café deste subsistema é considerada superior em comparação com os grãos encontrados em todo o setor. Para manter essa percepção do mercado, a illycaffè se mantém diferenciada pela sua estrutura organizacional. A compra de matéria-prima no Brasil é feita por um braço da importadora, a Experimental Agrícola do Brasil. Essa firma é responsável pela coordenação do arranjo brasileiro. As funções de seleção dos melhores grãos são munidas de um sistema de incentivos distintos do que o mercado oferece. A aquisição dos grãos ocorre usualmente por termos de intenção de venda e/ou contratos relacionais. A qualidade exigida é considerada restritiva. O nível elevado de parâmetros técnicos carrega a imprevisibilidade na possibilidade e quantia de fornecimento de café para a empresa. Usualmente, os cafeicultores brasileiros conseguem vender uma parcela mínima da sua safra para a empresa, normalmente variando de $2 \%$ a $10 \%$.

A fim de manter uma demanda razoável, a firma investe em incentivos financeiros com preços premium considerados bem acima da média do mercado e concursos de qualidade, além do caráter reputacional e as quase-rendas geradas pela função de ser um fornecedor da illycaffè, conforme apontado por Nunes, Saes, Rossignolo, Souza e Souza (2013). Após a aquisição da matéria-prima, o braço brasileiro da organização fica responsável pela exportação dos grãos para que a torrefadora italiana faça o beneficiamento e a distribuição do produto em lojas próprias com a marca illy.

A transação traz a especificidade de ativos como um fator presente nos fornecedores da illycaffè. Os investimentos são realizados com o intuito de manter a especialização necessária para agregar a qualidade exigida do grão. A alocação dos recursos é feita em processos produtivos nas etapas de plantio (sementes), colheita (tempo de maturação), póscolheita (separação, lavagem, secagem/fermentação) e pré-beneficiamento (descascamento, despolpamento). Além disso, as características de incerteza são minimizadas pela atuação da coordenação estrita, visto que o subsistema estritamente coordenado carrega um nível maior de coordenação e de proteção das quase-rendas da transação. 
Para concluir, o cenário exibido pela (6) já aparecia nas análises de Zylbersztajn et al. (1993) e Saes e Farina (1999). Entretanto, a estrutura passou por um processo de amadurecimento e chamou a atenção de outros agentes interessados em tal oportunidade, como, por exemplo, o sub SAG de café coordenado pela marca Nespresso.

(7) Cafés com certificação - Outra fonte de diferenciação do café emerge pelas orientações de mercado via certificações. As transações de cafés certificados eram poucas ou até inexistentes no período de desregulamentação do setor de café no Brasil, isto é, na década de 90 (Zylbersztajn et al.,1993; Saes \& Farina, 1999). Assim como no caso da qualidade, o mercado consumidor apenas passou a fornecer atenção a esse atributo nos últimos anos.

O sistema produtivo de café no Brasil é capaz de ofertar cafés certificados e diversificados. Os cafés com essas características podem ser tidos como de alta especificidade de ativos (física, humana e marca). A marca do selo carrega princípios que exigem investimentos em estruturas físicas e até especialização humana para emprego na propriedade.

Já na incerteza aparecem dois pontos. Um é a minimização da incerteza de mercado para o cafeicultor, pois o setor dos cafés certificados não possui a volatilidade do mercado do café commodity. E como segundo ponto aparece a minimização da incerteza pela diminuição da assimetria de informação para o consumidor, pois o monitoramento da certificadora é capaz de garantir os procedimentos adotados na produção agrícola.

As certificações conhecidas no SAG do café são: Rainforest Alliance; UTZ; Fair Trade; orgânico, sendo que cada tipo de certificação atende um nicho de mercado singular com seus requerimentos para participação.

A certificação Rainforest Alliance advém da Rede de Agricultura Sustentável (RAS) com foco na sustentabilidade mundial. A responsabilidade pela aplicação e monitoramento das normas no território brasileiro é do Instituto de Manejo e Certificação Florestal e Agrícola (Imaflora). Os principais objetivos da certificação da RAS é a melhoria contínua na gestão da propriedade agrícola, cumprimento de legislação trabalhista e ambiental, além da conservação dos recursos naturais. O selo pode ser indicado a fazendas de variados tamanhos e localização - seja como pessoa física ou jurídica.

O selo UTZ é da certificação Utz Kapeh com origem no mercado internacional. Esse enfoque ressalta a questão socioambiental. O programa envolve preservação do solo, fontes de energia e água, além do cuidado para com os trabalhadores quanto ao desenvolvimento financeiro e cultural. A inspeção credencia as propriedades anualmente. 
O selo de Fair Trade é originado na FairTrade International (F1O) pela sua unidade Flo-Cert. A certificação visa à transparência quanto às condições de trabalho, transparência para a cadeia como um todo, além de tornar os pequenos produtores de café menos dependentes de mecanismos informais de comercialização (leia-se "atravessadores"). Dessa forma, constata-se a busca pela garantia dos direitos básicos aos produtores pelos preços justos e das condições aos trabalhadores, usualmente à margem do mercado.

A certificação orgânica é realizada pela Associação de Certificação Instituto Biodinâmico (IBD) com base na Lei 10.831 de 23 de dezembro de 2003, e no Decreto 6.323 de 27 de dezembro de 2007. Esses marcos enfatizam a produção voltada para uma agricultura sem uso de substâncias tóxicas e químicas, ou seja, isenção de adubos, agrotóxicos químicos, além do não uso de organismos geneticamente modificados, antibióticos ou quaisquer produtos artificiais.

Cafeicultor e Indústria de Solúvel - A transação entre esses agentes passou a ganhar espaço dentro do SAG no Brasil. Este argumento possui seu pilar na comparação do atual cenário e na realidade dos anos de 1990 de Zylbersztajn et al. (1993) e Saes e Farina (1999), quando o mercado de solúvel era consideravelmente imaturo.

(8) A forma básica de relacionamento entre o cafeicultor e essa indústria ocorre por meio do mercado spot. A estrutura de coordenação é normalmente intermediada por cooperativas e corretores. A especificidade é baixa, tendo a referência de preço baseada no equilíbrio de oferta e demanda. A incerteza e frequência também acompanham o mesmo comportamento, sendo ambas pouco impactantes nas tomadas de decisão. O produto transacionado neste recorte é principalmente o de café robusta.

Indústria de Processamento e Indústria de Distribuição - Outra forma de negociação é exposta pela venda de cafés já industrializados e embalados para grandes redes de supermercado ou estabelecimentos com contato direto com os consumidores (padaria, restaurantes, cafeterias, livrarias). Outra forma é a venda para empresas públicas (por meio de licitações na entrega de cafés para consumo de funcionários públicos) ou privadas (mercado spot ou contratos de fornecimento de médio e longo prazo) no mercado doméstico e na exportação.

A transação entre os dois agentes é permeada pelas especificidades físicas e marca. $O$ produto beneficiado carrega investimentos em etapas produtivas anteriores. A marca aparece 
em virtude da percepção dos consumidores nas redes varejistas, tais como cafeterias, padarias, supermercados e outros, além da exposição em redes de atacado.

No cerne da incerteza surgem os três tipos. A incerteza de mercado é presente, mas minimizada pela característica da marca, pois é possível verificar um padrão preço pelo nome do produto, mesmo com as imprevisibilidades deste mercado. A incerteza tecnológica não se apresenta relevante. Esse fato é embasado na capacidade de investimentos das firmas desse setor, ou seja, o aporte de tecnologias é alcançável para esses agentes. Todavia, a incerteza institucional se destaca. Essa característica surge principalmente pelas normativas de exportações, visto que um país importador com instituições frágeis pode trazer oscilações em suas decisões.

Indústria de distribuição e consumidor final - As três características da transação influenciam as negociações de modo geral, porém a interferência nos mecanismos de governança pode ser considerada suave, pois o relacionamento encontra-se no final do sistema produtivo e dificulta processos de verticalização, por exemplo.

A principal coordenação entre ambos os agentes é a relação via mercado nas redes de supermercados ou cafeterias e padarias. Em excepcionalidades surgem contratos de fornecimento com o consumidor institucional, ou seja, aquisições de café em grandes quantidades para atendimento de uma empresa privada ou firmas públicas que realizam suas compras por regimentos específicos, como processos licitatórios e outros.

\subsection{Considerações finais sobre o SAG}

Pode-se dizer que o Sistema Agroindustrial de Café no Brasil apresenta peculiaridades ao longo da cadeia. O setor detém diferenças significativas nas estruturas de mercado, concentração das empresas líderes, tecnologias, formação de preços, assim como a atuação particular dos ambientes institucional e organizacional em cada contexto e as coordenações diferenciadas ao longo das transações do sistema produtivo.

$\mathrm{O}$ destaque é direcionado à transação do cafeicultor com a indústria de máquinas. $\mathrm{O}$ relacionamento carrega uma complexidade ainda inexplorada pela literatura que motivou a presente pesquisa. A estrutura organizacional do setor passou por uma transformação brusca pelo surgimento de firmas prestadoras de serviços especializados. O produtor obteve a possibilidade de decidir entre a compra do maquinário ou subcontratação de serviços. 
Dessa forma, a compreensão da transação tornou-se fundamental, já que a mão de obra na colheita é um aspecto significativo na formação dos custos de produção e, consequentemente, no desempenho econômico da cafeicultura. Sendo assim, as próximas seções buscarão aprofundar e desvendar os detalhes acerca dos determinantes na decisão do cafeicultor. 


\section{INDÚSTRIA DE MÁQUINAS E O CAFEICULTOR}

Este capítulo enfoca a transação entre os cafeicultores e a indústria de máquinas. A estrutura de análise se mantém conforme a estratégia adotada no capítulo anterior. Apresentase inicialmente o setor produtivo de maquinários, o ambiente organizacional e institucional que permeia o relacionamento, a transação e a forma de governança observada entre os agentes.

\subsection{Setor de Máquinas}

A indústria de equipamentos vem demonstrando importância no relacionamento com a produção agrícola de diversas culturas. O cenário brasileiro sofreu um crescimento de cerca de três vezes na produção de cultivadores, tratores, colheitadeiras e outros implementos. $\mathrm{O}$ avanço da mecanização é solidificado na agricultura do Brasil (Tabela 6).

Tabela 6 - Cenário da indústria de maquinários agrícolas (1993-2014) no Brasil

\begin{tabular}{lcccccc}
\hline & \multicolumn{1993}{c}{} & & & $\mathbf{2 0 1 4}$ & \\
\hline & Produção & Vendas & Exportação & Produção & Vendas & Exportação \\
$\begin{array}{l}\text { Cultivadores } \\
\text { motorizados }\end{array}$ & 1.403 & 1.096 & 336 & 1.566 & 1.553 & 5 \\
$\begin{array}{l}\text { Tratores de } \\
\text { rodas }\end{array}$ & 24.500 & 21.369 & 2.725 & 64.783 & 55.612 & 9.418 \\
$\begin{array}{l}\text { Tratores de } \\
\text { esteiras }\end{array}$ & 1.234 & 908 & 518 & 2.765 & 835 & 1.869 \\
$\begin{array}{l}\text { Colheitadeiras } \\
\text { Retroescava- }\end{array}$ & 3.445 & 2.735 & 611 & 7.623 & 6.448 & 1.026 \\
$\begin{array}{l}\text { Deiras } \\
\text { TOTAL }\end{array}$ & 1.595 & 1.272 & 293 & 5.581 & 4.161 & 1.423 \\
\hline
\end{tabular}

Fonte: Elaborado pelo autor com base em Associação Nacional dos Fabricantes de Veículos Automotores (ANFAVEA, 2014).

A produção de equipamentos específicos para o café se caracteriza pela concentração das empresas que fabricam as máquinas agrícolas. A receita estimada do setor de colhedoras e tratores para a cafeicultura foi de R \$ 1,5 bilhão, que representa cerca de $7 \%$ de todo o faturamento dos maquinários agrícolas (R\$ 9,9 bilhões) em $2012^{13}$ (Brazil Specialty Coffee Association [BSCA], 2012), sendo o grupo AGCO, por meio da marca Massey Ferguson, responsável por $50 \%$ da receita de vendas do montante de 2,6 mil tratores comercializados no

\footnotetext{
13 Informações sobre a indústria de máquinas para a cafeicultura não são disponibilizadas pelo setor. O dado desagregado para o setor de café foi apresentado unicamente no ano de 2012 pela Brazil Specialty Coffee Association por meio da estimativa apresentada na presente pesquisa.
} 
ano de 2011 para a cafeicultura (Associação Brasileira de Máquinas e Equipamentos [ABIMAQ], 2016).

Em 2014, a New Holland lançou uma colhedora multifuncional capaz de colher, pulverizar, podar e distribuir adubo. Já a Case IH e a Jacto apostaram na aproximação com o cafeicultor pela assistência técnica das novas concessionárias, principalmente no Estado de Minas Gerais. O reconhecimento de ambas se dá pelo avanço no nicho dos equipamentos de pequeno porte para colheita de café (derriçadeiras manuais) que as levaram à liderança deste segmento nos últimos anos. Outra firma do setor, a Pinhalense tem atuação nas regiões do interior de São Paulo e no Sul de Minas, com domínio de 30\% das vendas nesta última região (BSCA, 2012).

A liderança é permeada por aspectos regionais, diferenças tecnológicas e pelas estratégias de inserção do grupo concentrado de empresas que domina o setor. Já a formação de preço se diferencia pelas funcionalidades do produto, visto que colheitadeiras diferenciadas chegaram a ultrapassar o valor de $\mathrm{R} \$ 850.000,00$, contra a média de $\mathrm{R} \$ 500.000,00$ dos maquinários mais simples, no ano de 2016. A aquisição dos equipamentos é feita principalmente em feiras agrícolas.

\subsection{Ambiente Organizacional}

O relacionamento entre o cafeicultor e a indústria de máquinas, de modo particular as colheitadeiras agrícolas, é afetado por organizações com diferentes naturezas, tais como apoio financeiro, organizações de ação coletiva e institutos de pesquisa.

Organizações Financeiras - As organizações com objetivo de suporte financeiro são os bancos e eventualmente as "trading companies"14 que repassam crédito. O suporte acontece de modo distinto, de acordo com a realidade de cada cafeicultor. O envolvimento social do produtor com algumas organizações pode facilitar a obtenção de crédito para aquisição de maquinários, como, por exemplo, taxas e condições de empréstimos mais acessíveis. O detalhamento desse recorte recai especificamente sobre a atuação das linhas de financiamento do BNDES, visto que o banco oferta crédito por meio de programas (Finame Agrícola e Moderfrota) com alcance nacional e exigências iguais a todos os tomadores.

O Finame Agrícola é voltado para aquisição de máquinas, equipamentos e implementos agrícolas novos e com produção nacional para pessoa física, jurídica,

\footnotetext{
${ }^{14}$ Intermediária na operação de exportação ou de importação entre empresas fabricantes e compradoras.
} 
associações ou cooperativas. O programa pode realizar até $80 \%$ do financiamento do valor total da aquisição com o custo de $1,5 \%$ ao ano (a.a) como remuneração da organização, taxa de intermediação de 0,1 a 0,5\% a.a. O prazo máximo é de 90 meses, com carência de pagamento de até 02 anos. A solicitação desse recurso deve ser feita diretamente pelo produtor em uma instituição financeira credenciada, que é intermediária dessa relação. Todavia, o programa restringe o uso de seus recursos para aquisição de equipamentos com direcionamento à futura prestação de serviços para outros produtores (BNDES, 2011).

O Moderfrota foi ${ }^{15}$ direcionado ao mesmo público, porém sua atuação foi voltada para financiamento específico para tratores, colheitadeiras, pulverizadores, entre outros. A linha de crédito ampliou a possiblidade de aquisição de itens usados, com idade máxima de 08 anos para tratores, 10 anos para colheitadeiras, e demais itens com limite de 05 anos. $\mathrm{O}$ limite do valor foi de R $\$ 320.000,00$ para equipamentos para preparo, secagem e beneficiamento de café; $100 \%$ do valor do produto a ser adquirido para beneficiários do Programa Nacional de Apoio ao Médio Produtor Rural (Pronamp); e até 90\% para outro público. As taxas foram um pouco mais elevadas. Para solicitantes com receita anual de até 90 milhões de reais foi de $8,5 \%$ a.a., enquanto para clientes com receita superior a taxa foi de 10,5\% a.a. O prazo máximo dos financiamentos foi de no máximo 08 anos para itens novos e 04 para usados, ambos com no máximo 02 anos de carência (BNDES, 2015).

Organizações de ação coletiva, Sindicatos de trabalhadores rurais - A relevância desse agente na mecanização agrícola se dá pela sua atuação como movimento político (Medeiros, 1989).

A justificativa para a criação das entidades com esse objetivo foi a manutenção dos direitos trabalhistas do empregado rural. A criação dos sindicatos rurais ocorreu em 1963, com a fundação da Confederação Nacional dos Trabalhadores na Agricultura (Contag), e se estendeu com o surgimento dos sindicatos estaduais ou municipais (Confederação Nacional dos Trabalhadores na Agricultura [CONTAG], n.d.). Em 1983, outro agente relevante surge, a Central Única dos Trabalhadores (CUT). A CUT nasceu com características de movimento sindicalista, social e político com ênfase em diversos setores da economia, entre os quais a agricultura (Medeiros, 1989).

A atuação desses agentes pauta-se principalmente no viés político adotado pelas lideranças. A postura desses grupos contraria a possibilidade de terceirização de serviços, isto

\footnotetext{
${ }^{15}$ O Programa foi suspenso temporariamente em maio de 2016, contudo o caráter temporário da suspensão não exclui a relevância do Moderfrota, já que ele pode ser retomado.
} 
é, o posicionamento é contrário à subcontratação. Portanto, a influência na contratação externa é presente e atuante, porém sua interferência depende diretamente da força política e do poder dos sindicatos regionais frente às instituições locais.

Organizações de ação coletiva, Associações - Além da intervenção política dos sindicatos, existe a influência das associações na decisão de compra coletiva das colheitadeiras e tratores agrícolas. A união de produtores para aquisição coletiva de máquinas ocorre para diminuir o montante de investimento individual. A ação coletiva faz com que o produtor tenha que investir uma quantidade de capital menor em relação à compra individual da máquina. $\mathrm{O}$ investimento é dividido entre as partes, podendo ser em percentuais iguais ou não, a depender das normas definidas pelo grupo, tais como a política de uso, responsabilidades de manutenção e outros.

Institutos de pesquisa - Quanto às organizações de pesquisa, observa-se a importância das parcerias entre órgãos públicos e privados, ou seja, entre as indústrias e instituições de pesquisa. A relação se destaca pela responsabilidade na criação e constante renovação das principais máquinas da produção cafeeira, especificamente equipamentos voltados para a atividade da colheita (colheitadeiras e tratores agrícola) - principal enfoque da presente investigação.

Uma organização importante é o Instituto Agronômico de Campinas (IAC), que foi responsável pelo desenvolvimento inicial do equipamento de colheita mecânica nos cafezais brasileiros. Essa atividade foi realizada no início da década de 70 para avaliar a viabilidade econômica das máquinas nesse processo ${ }^{16}$. A partir dessa ação inicial, empresas privadas observaram os possíveis benefícios dessa vertente e passaram a realizar esforços com pesquisas e desenvolvimento, até o lançamento, em 1979, da primeira colheitadeira de café do mundo, o modelo denominado $\mathrm{K} 3$, com motor próprio e sistema hidráulico de regulagem de altura $^{17}$.

Posteriormente, novas iniciativas passaram a ocorrer, como, por exemplo, adaptações. É o caso da realização da retirada dos grãos da planta - a derriça unilateral - a partir do lançamento da Kokinha, em 1983; a derriça bilateral com a Koplex em 1986, além da parceria com a Universidade Federal de Lavras nas implementações na K3 de outros

\footnotetext{
${ }^{16} \mathrm{O}$ projeto inicial baseou-se na adaptação das colheitadeiras de cerejas.

${ }^{17} \mathrm{O}$ lançamento da primeira colheitadeira de café do mundo foi realizado pela empresa Máquinas Agrícolas Jacto.
} 
mecanismos, como saída dos grãos, sistema de abanação, proteção com cabine para condutor, acoplamento de depositório, sensor de volume colhido, além de tecnificação de sistemas de localização, condução e outros (Fundação Procafe [PROCAFE], 2013).

Além das parcerias com entidades públicas de pesquisa, o desenvolvimento de melhorias nos maquinários agrícolas recebeu fortes investimentos por parte de importantes produtoras de máquinas. A movimentação desses agentes foi consequência da adoção de mecanização da colheita na cafeicultura brasileira, incentivados pelo aumento dos custos das operações manuais. Os cafeicultores passaram por um período de mudança cultural na decisão de utilizar tecnologias agrícolas em operações de colheita, plantio e tratos culturais. A Case IH, Jaguar, Pinhalense, John Deere são exemplos de empresas privadas com atuação não só na venda, mas no processo de aperfeiçoamento das especificações das tecnologias.

A mecanização pode, todavia, ser realizada de modo parcial, por parte do agricultor. A semimecanização pode ser realizada como forma de maximizar ganhos em algumas etapas da colheita, em casos de impossibilidade de uso completo das máquinas. Dessa forma, faz-se necessária a exposição de diversas etapas desse processo da cultura cafeeira (Silva, Salvador, Pádua, \& Queiroz, 2001) - arruação, derriça, varrição e abanação:

Arruação: Operação minimizadora de contaminação dos grãos no contato com o solo, ajuste para possibilidade de uso de máquinas automotrizes e conservação da saudabilidade do solo e da planta. Esse processo ocorre pela limpeza da área ao redor do pé de café.

Derriça: Retirada dos grãos de café da planta. Ação que pode ocorrer com colhedora automotriz, manualmente ou derriçadeiras de pequeno porte, sendo que as duas últimas etapas realizam a derrubada do fruto diretamente no solo ou em tecidos.

Varrição: Recolhimento dos grãos que foram despejados no solo.

Abanação: Processo de limpeza e separação entre as impurezas, tais como detritos, galhos e folhas, e os grãos já colhidos.

As quatro etapas supracitadas ocorrem de modo simultâneo a partir do uso das colheitadeiras automotrizes, porém algumas atividades podem ocorrer individualmente, com o uso de outros equipamentos. Esse caso é o da colheita semimecanizada. Tal situação é explorada pelo uso das derriçadeiras portáteis. De acordo com a Empresa Brasileira de Pesquisa Agropecuária (EMBRAPA, 2012), o equipamento foi produzido pela parceria entre a cooperativa Cooxupé, a empresa Elexso e a Embrapa.

As derriçadeiras portáteis imitam o trabalho humano na atividade da derriça com o uso de pequenos motores para imitar os movimentos da mão do colhedor. As vantagens da 
adoção da ferramenta são a sua adaptação para uso em regiões acidentadas e a sua eficiência, visto que chega a operar com magnitude similar a de dois a quatro trabalhadores, além da necessidade de um menor montante de investimento em comparação ao de uma colheitadeira.

O início da adoção em massa de derriçadeiras ocorreu em 2004. A principal motivação do uso dos equipamentos foi a impossibilidade de atuação de automotrizes em regiões acidentadas ou com declividade maior do que $20 \%$, visto que este é o limite máximo para o uso das colheitadeiras e tratores. Ou seja, pode-se dizer que a adoção de tais ferramentas ocorreu principalmente nas áreas acidentadas ou montanhosas dos estados da Bahia, Espírito Santo e em algumas regiões de São Paulo e Minas Gerais, com marcas reconhecidas como a Brudden, Still, Shidaiwa, Dakimaq, Honda e com um preço médio de R\$ 1.200,00 contra o investimento médio de R \$500.000,00 para uma colheitadeira.

Portanto, de modo a concluir, notam-se três enfoques relevantes do ambiente organizacional quanto ao relacionamento do cafeicultor com a indústria de máquinas: o suporte financeiro, o histórico e o político.

O suporte financeiro é analisado pelo fornecimento de crédito diferenciado via bancos privados, públicos ou específicos para o agronegócio.

Já a característica histórica chamou a atenção pela origem da colheita mecanizada do café. O início do uso das máquinas ocorreu e se intensificou na década de 80 no estado de São Paulo e o processo migrou para a região do Cerrado Mineiro em razão de sua topografia. Até o início do século XXI, esse movimento permaneceu e apenas com a entrada das derriçadeiras a mecanização parcial passou a ser utilizada em regiões acidentadas como o Sul de Minas, Região das Matas e nos outros estados cafeeiros.

Enquanto isso a esfera política levantou o caráter de união da classe produtora nos casos das associações e seus maquinários coletivos e, especificamente, pelos movimentos sindicais e sua interferência geradora de conflitos na relação com as instituições - assunto a ser detalhado na próxima subseção.

\subsection{Ambiente Institucional}

Ao voltar para o ambiente institucional aparecem duas perspectivas. A primeira é a legislação vigente sobre a terceirização de serviços, a qual é representada pela Súmula 331 do Tribunal Superior do Trabalho (TST, 2011) ${ }^{18}$ exposta no Quadro 5. A outra advém do Projeto

\footnotetext{
${ }^{18}$ A súmula 331 trata dos contratos de prestação de serviços quanto à natureza da atividade contratada e da empresa contratante.
} 
de Lei $n^{\circ}$ 4330/2004 (Brasil, 2004), o qual foi aprovado pela Câmara dos Deputados e no Senado Federal, porém a assinatura pela Presidência da República e fixação como uma lei nacional ainda está em discussão ${ }^{19}$.

\section{Quadro 5 - Súmula n 331 do TST}

\begin{tabular}{|c|c|}
\hline ITEM & \\
\hline $\mathbf{I}$ & $\begin{array}{l}\text { A contratação de trabalhadores por empresa interposta é ilegal, formando-se o vínculo } \\
\text { diretamente com o tomador dos serviços, salvo no caso de trabalho temporário. }\end{array}$ \\
\hline II & $\begin{array}{l}\text { A contratação irregular de trabalhador, mediante empresa interposta, não gera vínculo } \\
\text { de emprego com os órgãos da Administração Pública direta, indireta ou fundacional. }\end{array}$ \\
\hline III & $\begin{array}{l}\text { Não forma vínculo de emprego com o tomador a contratação de serviços de vigilância } \\
\text { (Lei } n^{\circ} 7.102 \text {, de } 20.06 .1983 \text { ) e de conservação e limpeza, bem como a de serviços } \\
\text { especializados ligados à atividade-meio do tomador, desde que inexistente a } \\
\text { pessoalidade e a subordinação direta. }\end{array}$ \\
\hline IV & $\begin{array}{l}\text { O inadimplemento das obrigações trabalhistas, por parte do empregador, implica a } \\
\text { responsabilidade subsidiária do tomador dos serviços quanto àquelas obrigações, } \\
\text { desde que haja participado da relação processual e conste também do título executivo } \\
\text { judicial. }\end{array}$ \\
\hline V & $\begin{array}{l}\text { Os entes integrantes da Administração Pública direta e indireta respondem } \\
\text { subsidiariamente, nas mesmas condições do item IV, caso evidenciada a sua conduta } \\
\text { culposa no cumprimento das obrigações da Lei n. }{ }^{\circ} 8.666 \text {, de 21.06.1993, } \\
\text { especialmente na fiscalização do cumprimento das obrigações contratuais e legais da } \\
\text { prestadora de serviço como empregadora. A aludida responsabilidade não decorre de } \\
\text { mero inadimplemento das obrigações trabalhistas assumidas pela empresa } \\
\text { regularmente contratada. }\end{array}$ \\
\hline VI & $\begin{array}{l}\text { A responsabilidade subsidiária do tomador de serviços abrange todas as verbas } \\
\text { decorrentes da condenação referentes ao período da prestação laboral. }\end{array}$ \\
\hline
\end{tabular}

Fonte: Elaborado pelo autor com base em TST (2011).

A súmula apresenta que o vínculo de responsabilidade por parte de um trabalhador terceirizado também é da contratante. As obrigações trabalhistas - impostos, condições de trabalho, salários, entre outros - recaem subsidiariamente sobre a tomadora dos serviços em

\footnotetext{
${ }^{19} \mathrm{O}$ projeto de lei ainda é alvo de debate no poder legislativo no Brasil. O PL está com possibilidade de sofrer alterações em seu conteúdo original por meio de medidas provisórias.
} 
casos de irregularidades, logo, o monitoramento da legalidade para com o empregado é incumbência de ambas as partes. Portanto, pode-se dizer que a contratante pode ser responsável em pagamentos de verbas referente ao processo de contratação em face de processos judiciais.

A regulação ressalta outros pontos quanto à natureza dos serviços prestados. A relevância do assunto recai sobre a incerteza na proibição, ou não, da terceirização de serviços para atividade-fim. Essa ação abre espaço para a interpretação específica para cada caso, pois a definição para atividade-meio ou atividade-fim varia de acordo com as operações e setor em análise e pelo esclarecimento da instituição em si. Especificamente, o ambiente institucional age por meio do monitoramento do Ministério Público do Trabalho (MPT), o qual realiza a fiscalização e cumprimento da legislação com base na Súmula 331, visto que os contratos de prestação de serviços não possuem uma lei específica para serem regulados, mas sim precedentes jurídicos fundamentados no código civil.

Observando essa lacuna, a interação entre o mercado e o ambiente institucional proveu feedbacks suficientes para que ações no sentido de adaptação regulatórias fossem tomadas. Como uma forma de definir estabilidade para situações de terceirização, elaborou-se o Projeto de Lei (PL) 4330/2004 com o objetivo de regulamentar os contratos de terceirização no mercado de trabalho. A potencial legislação com aprovação na Câmara dos Deputados e em andamento no Senado Federal traz contrapontos ao exposto pela Súmula do TST e, portanto, a exposição de alguns de seus artigos torna-se necessária (Quadro 6).

Quadro 6 - Pontos impactantes do Projeto de Lei 4330/2004

\begin{tabular}{ll}
\hline ITEM & \multicolumn{2}{c}{ DESCRIÇão } \\
\hline Art. & Não se configura vínculo empregatício entre a empresa contratante e os \\
$\mathbf{2}^{\mathbf{o}} \S$ & trabalhadores ou sócios das empresas prestadoras de serviços, qualquer que seja o \\
$\mathbf{2}^{\mathbf{o}}$ & seu ramo. \\
\hline Art. & O contrato de prestação de serviços pode versar sobre o desenvolvimento de \\
$\mathbf{4}^{\mathbf{o}} \mathbf{\S}$ & atividades inerentes, acessórias ou complementares à atividade econômica da \\
$\mathbf{2}^{\mathbf{o}}$ & contratante. \\
\hline Art. & São permitidas sucessivas contratações do trabalhador por diferentes empresas \\
$\mathbf{5}^{\mathbf{0}}$ & prestadoras de serviços a terceiros, que prestem serviços à mesma contratante de \\
& forma consecutiva. \\
\hline Art & A empresa prestadora de serviços a terceiros, que subcontratar outra empresa
\end{tabular}

Art. A empresa prestadora de serviços a terceiros, que subcontratar outra empresa 
\begin{tabular}{ll}
\hline 11 $^{\mathbf{0}}$ para a execução do serviço, é solidariamente responsável pelas obrigações \\
trabalhistas assumidas pela empresa subcontratada.
\end{tabular}

Fonte: Elaborado pelo autor com base em Brasil (2004).

O PL afirma em seu texto que não há configuração de vínculo empregatício, nem parcial, entre o contratante e a prestadora de serviço. E, diferentemente da atual regulamentação, a proposta possibilita a terceirização de quaisquer atividades, sejam as chamadas atividades fim ou não, assim como possibilita a continuidade dos serviços do empregado terceirizado a partir da troca da prestadora contratada. A potencial lei trata a mudança do trabalhador para outra empresa como garantido com base no contrato anterior, isto é, as funções podem permanecer, sendo apenas necessária a alocação do vínculo empregatício do próprio empregado para a nova firma.

Ainda como pontos de conflito, surgem a mudança de responsabilidade sobre refeição e transporte para o contratante e a proibição de vínculo do proprietário da prestadora de serviço com a tomadora, seja como sócio ou por um laço empregatício, e por fim, a exposição de responsabilidade da prestadora sobre quaisquer conflitos em casos de quarteirização. Essa última situação é refletida quando uma firma contratada realiza a contratação de outra empresa para que o serviço, que era de sua responsabilidade, passe a ser cumprido por esta última. Vale ressaltar que a súmula do TST não trata deste posicionamento, isto é, o seu uso é possível, visto que não há impeditivo legal para a adoção dessa prática.

Dessa forma, expostas as contradições entre ambas as regulações, verifica-se que a cafeicultura brasileira possui incerteza quanto ao ambiente institucional que limita, ou não, a terceirização dos serviços de mecanização agrícola. É possível observar situações em que ocorre a proibição do uso desse arranjo institucional por parte do produtor, enquanto em outras há a abertura para a subcontratação. Essas ações são decorrentes de decisões de procuradores do trabalho em investigações realizadas pelo MPT. Caso constatada a veracidade da ocorrência é elaborado um documento processual formal denominada Termo de Ajustamento de Conduta (TAC), de acordo com a situação. O TAC é a formalização dos achados da investigação e denota os pontos em que é necessário mudança, assim como prazos e multas em casos de descumprimento na adequação das irregularidades encontradas na propriedade.

Portanto, conforme já mencionado, a proibição na adoção ou não de terceirização da mecanização da colheita é incerta. Assim como exposto por Mascarin (2014), é possível encontrar decisões que possibilitam o uso de prestadoras de serviços para essa atividade na 
cultura de milho (Ministério Público do Trabalho [MPT], 2010a), e outras que vão em direção contrária, como, por exemplo, a proibição de terceirizar as atividades, consideradas pelos processos como finalísticas, nos termos: no 20100259 de 29/09/2010 (MPT, 2010b) e $n^{\text {o }}$ 512013 de 17/05/2013 (MPT, 2013) para a cultura de cana-de-açúcar.

A contradição nas posturas adotadas pelos agentes do ambiente institucional se repete na cafeicultura. O Termo de Ajustamento de Conduta n ${ }^{\circ}$ 094/2005 de 12/05/2005 da $18^{\text {a }}$ Região (Goiás) (MPT, 2005a) compreende a possibilidade de terceirização de serviço de mecanização da colheita como procedente e legal, sendo sua proibição apresentada apenas para terceirização de empregado e não do pacote de serviço (condutor e máquina), isto é, age exclusivamente para abster o cafeicultor de ter os próprios equipamentos e contratar apenas um empregado, mas não o proíbe de contratar o serviço, conforme segue:

CLÁUSULA PRIMEIRA - O Compromissário deverá abster-se de terceirizar suas atividades finalísticas, assim compreendidas aquelas necessárias à consecução de seus objetivos sociais, incluindo as atividades relacionadas ao cultivo e à colheita de café e outros produtos agrícolas, devendo contratar diretamente a mão-de-obra indispensável para execução dos referidos serviços, vedando-se a contratação de trabalhadores através de gatos, intermediários ou empreiteiros.

PARÁGRAFO ÚNICO - Ficam excluídas da proibição constante do caput as operações passíveis de execução através de máquinas e/ou equipamentos agrícolas e que sejam desempenhadas por empresas especializadas, como por exemplo, o plantio, a pulverização, a colheita, o transporte e a capina mecânica, assim como os serviços especializados de assessoria técnica agrícola (MPT, 2005a, p. 1)

Enquanto no TAC de $n^{\circ}$ 6877/2009 de 12/11/2009 da 15a Região (Campinas/SP) (MPT, 2009), o procurador desautoriza a contratação externa de tais tipos de serviço conforme abaixo:

1.1. Não mais tomar serviços terceirizados para atividades rurais de quaisquer espécie, haja vista a Lei $\mathrm{n}^{\circ} 5889 / 1973$ estabelecer, apenas, a formação de vínculo de emprego diretamente com as pessoas que exploram a atividade agroeconômica. (MPT, 2009, p. 2)

A controvérsia entre tais medidas é presente. $\mathrm{O}$ ponto de maior indagação é a comparação do TAC n ${ }^{\text {0 }}$ 094/2005 citado inicialmente e o TAC no 008/2005 (MPT, 2005a, 2005b). Ambos os documentos foram emitidos no ano de 2005 e ainda pelo mesmo Procurador do Trabalho de Goiás. Ao realizar a associação do parecer emitido nas duas contestações surge a imprevisibilidade das decisões. O primeiro termo possibilita o uso de terceiros para a colheita, já o outro desaprova. O trecho do segundo termo que exibe tal raciocínio é: 
CLÁUSULA PRIMEIRA - Os Compromissários deverão abster-se de terceirizar suas atividades finalísticas, assim compreendidas aquelas necessárias à consecução de seus objetivos sociais, incluindo todas as atividades relacionadas ao cultivo e à colheita de café e outros produtos agrícolas, devendo contratar diretamente a mão-de-obra indispensável para execução dos referidos serviços, vedando-se a contratação de trabalhadores através de gatos, intermediários ou empreiteiros (MPT, 2005b, p.1).

Conforme exposto, as controvérsias de tais decisões podem ser explicadas pela forte influência sindical nas regiões. Ambos os Estados (GO e SP) possuem entidades de classe com forte atuação política, como a Federação dos Trabalhadores na Agricultura do estado de Goiás (FETAEG), o Sindicato dos Trabalhadores Rurais da Grande São Paulo, Federação dos Empregados Rurais e Assalariados do Estado de São Paulo (FERAESP).

Os dois documentos emitidos em Goiás se contrapõem, o que indica que podem ter sofrido influência pelo avanço na atuação da FETAEG no ano de 2005. Notícias veiculadas no portal da entidade (FETAEG, 2005) apresentam fortificação do braço sindical voltado à imersão política em órgãos capazes de decidir questões trabalhistas rurais. As ações do período buscaram aumentar a atividade nas regionais sindicais e, consequentemente, a retomada das operações pode ter modificado as decisões institucionais acerca da mecanização agrícola, visto que a representação desse órgão é munida de uma natureza conservadora e diversas vezes com viés contrário à inserção tecnológica no campo pela prestação de serviço.

Os casos de interferência nas decisões das instituições no estado de São Paulo repetem o mesmo embasamento. Os anos de 2005 e 2009 coincidiram com as eleições presidenciais e o favoritismo estava voltado para o Partido dos Trabalhadores (PT), o qual se encontrava na Presidência da República e mantinha relacionamento com a CUT e outras forças sindicais. Portanto, os movimentos sindicalistas ganharam força e atenção nesse período, o que pode ter ocasionado maior interferência nas causas trabalhistas direcionadas à temática de terceirização, visto que a indústria de prestação de serviços de colheita mecanizada é recente e incapaz de realizar lobby a seu favor.

Assim, nasce a dúvida: qual a real medida a ser seguida pela classe produtora rural para permanecer na legalidade? Diante dessas intermediações, sugere-se que a decisão de subcontratação deve ser pautada pela lógica econômica do subcontratante, ou seja, caso seja viável economicamente a terceirização em sua propriedade, tal medida deverá ser adotada, visto que a possibilidade de problemas trabalhista é imprevisível. 


\subsection{Transação de colheita mecanizada}

A transação entre os cafeicultores e a indústria de maquinários é permeada principalmente por ações referentes à mão de obra na atividade da colheita. Na cadeia do café é possível notar o uso de três diferentes tipos de colheita: manual, semimecanizada ou mecanizada.

A mão de obra manual é caracterizada pelo uso exclusivo de trabalhadores ${ }^{20}$, sem adoção de máquinas e/ou equipamentos para qualquer etapa da colheita, visto que a atividade consiste em coletar a dedo ou derriçar o ramo inteiro do cafeeiro com a própria mão. Este exemplo surge pela contratação de mão de obra temporária para atendimento de serviços sazonais (colheita). A peculiaridade é a contratação contínua em longo prazo de um mesmo indivíduo como, por exemplo, alguns trabalhadores que já mantêm essa regularidade de cerca de dez anos na prestação de serviço para o mesmo produtor. Acabam surgindo alguns benefícios além da própria contratação como a oportunidade de moradia em uma propriedade rural tanto para o funcionário quanto para sua família. Outra situação curiosa, ainda, é o fornecimento de moradia na propriedade rural para trabalhadores fixos em conjunto com sua família, ou seja, o fornecimento de incentivos em forma de alojamento, visto que há uma transformação desse ambiente em um cenário de harmonia e até convivência entre diversas famílias - de outros empregados e do proprietário.

A colheita semimecanizada consiste na adoção de derriçadeiras portáteis que assumem a mesma função da derriça braçal, porém por um equipamento de pequeno porte capaz de alcançar pontos mais elevados do pé de café. Esse tipo de mão de obra surge usualmente em face da dificuldade do uso das máquinas, já que a tecnologia é limitada para terrenos muito acidentados. E ainda, a semimecanização aparece como respostas de minimização de mão de obra, pois as derriçadeiras substituem cerca do trabalho de três indivíduos. Essa estrutura de trabalho está se expandindo em regiões como Rondônia, além de já estar consolidada na Chapada e no Sul de Minas Gerais e na Região das Matas.

Quanto à colheita mecanizada, sua adoção pode trazer ganhos de eficiência devido às tecnologias e à representatividade de custos que a mão de obra possui na colheita do café. Contudo, o uso de maquinários apresenta seus obstáculos, por exemplo, a alocação de um montante considerável de recursos para sua aquisição. Em face dessa exigência e a fim de ultrapassá-la, dois cenários emergem como soluções alternativas. O primeiro, com as firmas

\footnotetext{
${ }^{20} \mathrm{O}$ conceito da colheita manual pode ser diferente da definição escolhida para a análise da presente pesquisa (Silva \& Salvador, 1998; Silva, Salvador, Pádua, \& Queiroz, 2001). Optou-se pelo uso dessa explicação para facilitar a compreensão do leitor sobre os três diferentes tipos de colheita.
} 
prestadoras de serviços de mecanização agrícola, e o segundo, com os maquinários compartilhados nas organizações de ações coletivas.

As organizações de ações coletivas aproximam os agentes e fortificam as relações informais por meio dos laços sociais. A aproximação entre a classe de cafeicultores acarreta formas organizacionais diferenciadas das tradicionais. No setor cafeeiro, nota-se a existência de produtores como fornecedores de serviços informais, diferentes da subcontratação de serviços especializados de firmas especializadas. Esse cenário é permeado por coordenação relacional, visto que é um acordo informal entre pessoas com envolvimento social. Vizinhos, parentes, colegas de cooperativa ou de associação realizam acordos entre eles para prestação de serviço sem formalização por contrato, sendo as responsabilidades acordadas verbalmente, assim como a própria remuneração que muitas vezes passa a ocorrer por meio de troca de outros serviços, produtos diversos, sacas de café ou dinheiro.

Entretanto, essa estrutura é munida de informalidade e o seu reconhecimento legal é inexistente. Dessa forma, pode-se dizer que as duas principais formas de relacionamento entre o cafeicultor e a indústria de máquinas ocorrem pela prestação de serviço formal (subcontratação) e o uso de maquinários próprios (integração vertical).

\subsection{Considerações finais sobre a transação do cafeicultor e a indústria de máquinas}

Essa seção apresentou o setor de máquinas agrícolas. As empresas líderes de mercado se diferenciam por pequenas adaptações na tecnologia já amplamente produzida. Dessa forma, as estratégias para maximização do lucro se atêm à inserção de funcionalidades diferenciais nos equipamentos e, a partir disso, nasce a distinção dos preços entre as firmas do setor, como no caso das máquinas com sistemas de geolocalização, funções de pulverização, entre outras.

Quanto às organizações, dois pontos podem ser ressaltados. Primeiramente, observase a existência de políticas públicas para oferta de crédito para melhoramento tecnológico nos processos produtivos agrícolas. As linhas de financiamento auxiliam não somente os cafeicultores na aquisição dos maquinários próprios, mas também funcionam como um apoio indireto para a indústria de máquinas em virtude da facilitação de crédito. E segundo, aparece a forte atuação dos movimentos sindicais. A ação dos sindicatos é direcionada majoritariamente contra a terceirização. As entidades apontam a preocupação com o empregado como principal motivador de suas condutas, contudo a fundamentação do movimento é contraditória, pois, mesmo que o serviço não ocorra pela contratação direta do 
trabalhador pelo cafeicultor, há o vínculo empregatício do empregado com a prestadora de serviço subcontratada. Dessa forma, os direitos do funcionário são garantidos em ambas as situações, ou seja, o objetivo do sindicato de proteger os direitos trabalhistas permanece tanto quando há contratação direta ou quando ocorre a terceirização do serviço.

Este capítulo levantou ainda pontos de divergência quanto à atuação do ambiente institucional, pois a legislação vigente diverge das possíveis alterações propostas pelo projeto de lei em vias de aprovação. Percebem-se situações de conflito com o ambiente institucional na substituição de mão de obra pela mecanizada a partir da terceirização nos sistemas agrícolas brasileiros. A legislação trabalhista do Brasil apresenta alguns obstáculos quanto à realização desse avanço frente ao uso de novos processos produtivos, logo, alguns impasses são impostos pelo Judiciário e pela ação individual de alguns juízes em específico.

Para concluir, percebe-se a influência do ambiente organizacional e institucional como importante na decisão de comprar ou subcontratar na transação de colheita mecanizada. Entretanto, outros fatores mais voltados à realidade do cafeicultor podem interferir nessa escolha, conforme apresentado no Capítulo 2. Dessa forma, o próximo capítulo aborda as interferências nesta escolha com base nas estatísticas descritivas da amostra e no modelo econométrico com alicerce na Economia de Custos de Transação. 


\section{RESULTADOS QUANTITATIVOS}

Os resultados desta pesquisa baseiam-se na aplicação do modelo aos dados coletados nos 105 questionários obtidos com cafeicultores nas regiões de Minas Gerais e São Paulo entre dezembro de 2015 a abril de 2016. Os dados buscam alcançar o objetivo "iii" que tem como fim apresentar os determinantes na subcontratação de mecanização agrícola da colheita na cafeicultura no Brasil. O presente capítulo se divide em duas partes. Primeiramente, realiza-se a exposição das estatísticas descritivas. Em seguida, é apresentado o modelo econométrico que testa as hipóteses acerca do objeto estudado - transação de mecanização agrícola da colheita nos cafezais. Para tanto, a pesquisa parte de alguns pressupostos:

a) A decisão de subcontratar a transação de mecanização agrícola da colheita do cafeicultor está relacionada à especificidade de ativos, incerteza e path dependence.

b) Considerando os investimentos específicos da transação, a especificidade está relacionada à adoção do uso dos maquinários próprios.

c) A incerteza se associa com problemas com processos jurídicos e imprevisibilidade nas decisões dos tribunais a partir do ambiente institucional, que, por sua vez, induz à verticalização como forma de minimizar tais situações.

d) O path dependence é marcado pela restrição na tomada de decisões do produtor, na decisão de manter o uso de mecanização por meio de maquinários próprios, os quais exigiram investimentos de capital no passado.

\subsection{Caracterizando o perfil do cafeicultor}

A descrição dos resultados é feita pela divisão dos produtores que subcontratam ou que verticalizam a mecanização da colheita, o que facilita a análise sob o posicionamento da Economia de Custos de Transação (ECT). Ainda, a divisão se pauta nas seguintes categorias: i) perfil do produtor e da propriedade; ii) especificações da atividade de mecanização da colheita; iii) características das prestadoras de serviço, ambiente contratual e tecnológico. 


\subsubsection{O perfil do produtor e da propriedade}

A variabilidade nas características da propriedade e do cafeicultor denota a diversidade na amostra. O perfil do produtor e da propriedade é apresentado pela Tabela 7.

Tabela 7 - Perfil da propriedade e dos cafeicultores

\begin{tabular}{|c|c|c|c|c|}
\hline & \multicolumn{2}{|c|}{ Subcontrata } & \multicolumn{2}{|c|}{ Verticaliza } \\
\hline \multicolumn{5}{|c|}{ Localização da propriedade } \\
\hline UF & Qtde & $\%$ & Qtde & $\%$ \\
\hline MG & 34 & $32,4 \%$ & 47 & $44,8 \%$ \\
\hline SP & 11 & $10,5 \%$ & 13 & $12,3 \%$ \\
\hline \multicolumn{5}{|c|}{ Nível de Escolaridade } \\
\hline Sem escolaridade & 0 & $0,0 \%$ & 2 & $1,9 \%$ \\
\hline Nível fundamental & 8 & $7,6 \%$ & 23 & $21,9 \%$ \\
\hline Nível médio & 10 & $9,5 \%$ & 15 & $14,3 \%$ \\
\hline Nível superior & 27 & $25,7 \%$ & 20 & $19,0 \%$ \\
\hline Tempo de estudo com educação formal (média em anos) & \multicolumn{2}{|c|}{14,7} & \multicolumn{2}{|c|}{11,3} \\
\hline \multicolumn{5}{|l|}{ Tradição } \\
\hline $1^{a}$ geração & 16 & $15,2 \%$ & 15 & $14,3 \%$ \\
\hline $2^{\mathrm{a}}$ geração & 16 & $15,2 \%$ & 19 & $18,1 \%$ \\
\hline $3^{\mathrm{a}}$ geração & 4 & $3,8 \%$ & 16 & $15,2 \%$ \\
\hline$>3^{\mathrm{a}}$ geração & 9 & $8,6 \%$ & 10 & $9,5 \%$ \\
\hline Tempo de cafeicultura da família (média em anos) & \multicolumn{2}{|c|}{56,4} & \multicolumn{2}{|c|}{57} \\
\hline Tempo de cafeicultura do produtor (média em anos) & \multicolumn{2}{|c|}{21,5} & \multicolumn{2}{|c|}{25,4} \\
\hline \multicolumn{5}{|c|}{ Presença em cooperativa ou associação } \\
\hline Sim & 44 & $41,9 \%$ & 56 & $53,3 \%$ \\
\hline Não & 1 & $1,0 \%$ & 4 & $3,8 \%$ \\
\hline $\begin{array}{c}\text { Tempo de participação em cooperativas ou associações } \\
\text { (média em anos) }\end{array}$ & \multicolumn{2}{|c|}{14,5} & \multicolumn{2}{|c|}{14,7} \\
\hline \multicolumn{5}{|c|}{ Estrutura da propriedade } \\
\hline Idade do cafezal (média em anos) & \multicolumn{2}{|c|}{11,35} & \multicolumn{2}{|c|}{12,3} \\
\hline Hectares (hec) & \multicolumn{2}{|c|}{68,1} & \multicolumn{2}{|c|}{101,8} \\
\hline Sacas de produção $(\mathrm{sc})$ & \multicolumn{2}{|c|}{542,71} & \multicolumn{2}{|c|}{82,9} \\
\hline Média de trabalhadores fixos ( $\mathrm{n}^{\circ}$ de empregados) & \multicolumn{2}{|c|}{5} & \multicolumn{2}{|c|}{10} \\
\hline Média de trabalhadores temporários ( $\mathrm{n}^{\circ}$ de empregados) & \multicolumn{2}{|c|}{12} & \multicolumn{2}{|c|}{21} \\
\hline
\end{tabular}

Fonte: Elaborado pelo autor

Dentre os produtores que não contratam o serviço, 44,8\% (47) são do estado de Minas Gerais e 12,3\% (13) de São Paulo, enquanto para aqueles que utilizam a subcontratação esse número se altera para 32,4\% (34) e 10,5\% (11), respectivamente. Em relação ao nível de escolaridade, há uma concentração de cafeicultores com nível superior de $25,7 \%$ (27) e com média de 14,7 anos de estudos que faz uso dos contratos; e 23,8\% (25) do total da amostra representam os agentes sem escolaridade ou só com nível fundamental e os com 11,3 anos de estudos, em média, que não utilizam os contratos. A variável escolaridade mostra que, dentro do grupo dos subcontratantes, todos os produtores possuem educação formal. 
A partir da escolaridade infere-se que o conhecimento genérico do produtor pode ser associado com a capacidade de interpretar informações, em outras palavras, pode diminuir a incidência de problemas em relacionamentos contratuais (Simon, 1955; Hermalin, Katz \& Craswell, 2007). A competência de interpretação de cláusulas contratuais diminui a incerteza do ambiente e propicia a adoção dos contratos da prestação de serviços, o que ocorreu conforme a exposição dos dados sobre nível de escolaridade e anos de estudo.

Conforme indicado na Tabela 7, a tradição na atividade é mais presente nos cafeicultores que não utilizam os contratos, pois $24,7 \%$ (26) são da $3^{\mathrm{a}}$ e $4^{\mathrm{a}}$ geração, enquanto no outro grupo a representatividade é de 3,8\% (4) e 8,6\% (9), respectivamente.

Quanto ao tempo de contato com a atividade de cafeicultura do próprio entrevistado, os subcontratantes denotam menor experiência na atividade, com uma média de 21,5 anos contra uma média de 25,4 do outro grupo. Posto isso, observa-se a presença do conceito de path dependence de North (1990), pois os dados caracterizam o conservadorismo nas tomadas de decisão quanto ao uso dos próprios maquinários conforme a tradição da família na cafeicultura. Os resultados também apontam que o contato de apenas uma geração não é suficiente para influenciar essa decisão e, dessa forma, demonstra que a formação de path dependence apenas ocorre após um longo período de tempo.

A participação em ações coletivas parece não interferir na decisão de subcontratar a mecanização, visto que 53,3\% (56) dos respondentes que não utilizam a subcontratação de mecanização estão presentes em uma cooperativa ou associação, assim como 41,9\% (44) dos cafeicultores que usam subcontratam também fazem parte de uma dessas ações coletivas. $\mathrm{O}$ reforço dessa observação encontra-se na média de participação, próxima dos 14 anos em ambos os grupos.

Quanto à estrutura da propriedade, observa-se que na idade do cafezal a diferença entre os dois grupos é mínima. Ambos os grupos possuem médias próximas a 12 anos, isto é, o fator de tempo na lavoura parece não influenciar na decisão de subcontratar ou não. Dentro do grupo que subcontrata há uma média menor de trabalhadores em sua propriedade - fixo (5) e temporário (12), pois os cafeicultores que verticalizam a transação apresentam uma quantidade maior de empregados, com uma média de 10 fixos e 21 temporários. Posto isso, pode-se dizer que esses resultados mostram que os cafeicultores estão adotando a subcontratação como forma de complementação de mecanização dos seus próprios maquinários.

Com foco nas economias de escala e capacidade de imobilização de capital, nota-se uma média de 101 hectares dentre os produtores que não subcontratam, contra 68 hectares 
daqueles que utilizam a prestação de serviços. O cenário se se altera ao olhar a eficiência da produção, já que há uma média de 82,9 sacas de café para os que verticalizam e 542,71 sacas de café do outro grupo.

\subsubsection{Especificações da atividade de mecanização da colheita}

Ao voltar para as especificações da atividade de mecanização surge a apresentação dos resultados encontrados, por meio da Tabela 8 .

Tabela 8 - Características da mecanização da colheita

\begin{tabular}{|c|c|c|c|c|}
\hline & \multicolumn{2}{|c|}{ Subcontrata } & \multicolumn{2}{|c|}{ Verticaliza } \\
\hline \multicolumn{5}{|c|}{ Origem dos maquinários } \\
\hline & Qtde & $\%$ & Qtde & $\%$ \\
\hline Equipamentos próprios & 37 & $35,2 \%$ & 60 & $57,1 \%$ \\
\hline Empresa prestadora de serviços & 8 & $7,6 \%$ & 0 & $0,0 \%$ \\
\hline \multicolumn{5}{|c|}{ Escala crescente de tendência de compartilhamento } \\
\hline 1 & 11 & $10,5 \%$ & 24 & $22,9 \%$ \\
\hline 2 & 9 & $8,6 \%$ & 7 & $6,7 \%$ \\
\hline 3 & 8 & $7,6 \%$ & 11 & $10,5 \%$ \\
\hline 4 & 6 & $5,7 \%$ & 4 & $3,8 \%$ \\
\hline 5 & 11 & $10,5 \%$ & 14 & $13,3 \%$ \\
\hline \multicolumn{5}{|c|}{ Escala de capital imobilizado em equipamentos específicos para a cafeicultura } \\
\hline Até $\mathrm{R} \$ 50.000,00$ & 1 & $1,0 \%$ & 8 & $7,6 \%$ \\
\hline De R\$ 50.000,01 a R\$ 100.000,00 & 7 & $6,7 \%$ & 10 & $9,5 \%$ \\
\hline De R\$ $100.000,01$ a $R \$ 200.000,00$ & 4 & $3,8 \%$ & 2 & $1,9 \%$ \\
\hline De $\mathrm{R} \$ 200.000,01$ a $\mathrm{R} \$ 300.000,00$ & 7 & $4,8 \%$ & 2 & $1,9 \%$ \\
\hline De $\mathrm{R} \$ 300.000,01$ a $\mathrm{R} \$ 400.000,00$ & 5 & $3,8 \%$ & 1 & $1,0 \%$ \\
\hline Mais que $\mathrm{R} \$ 400.000,00$ & 21 & $20,0 \%$ & 37 & $17,1 \%$ \\
\hline Não possuo maquinários & 0 & $0,0 \%$ & 0 & $0,0 \%$ \\
\hline \multicolumn{5}{|c|}{ Escala crescente de importância do treinamento } \\
\hline 1 & 0 & $0,0 \%$ & 0 & $0,0 \%$ \\
\hline 2 & 1 & $1,0 \%$ & 0 & $0,0 \%$ \\
\hline 3 & 2 & $1,9 \%$ & 3 & $2,9 \%$ \\
\hline 4 & 5 & $4,8 \%$ & 9 & $8,6 \%$ \\
\hline 5 & 37 & $35,2 \%$ & 48 & $45,7 \%$ \\
\hline \multicolumn{5}{|c|}{ Escala crescente de complexidade e custo para revisão das máquinas } \\
\hline 1 & 2 & $1,9 \%$ & 6 & $5,7 \%$ \\
\hline 2 & 2 & $1,9 \%$ & 5 & $4,8 \%$ \\
\hline 3 & 24 & $22,9 \%$ & 32 & $30,5 \%$ \\
\hline 4 & 7 & $6,7 \%$ & 8 & $7,6 \%$ \\
\hline 5 & 10 & $9,5 \%$ & 9 & $8,6 \%$ \\
\hline \multicolumn{5}{|c|}{ Escala crescente de perdas de valor pelo atraso na colheita } \\
\hline 1 & 6 & $5,7 \%$ & 3 & $2,9 \%$ \\
\hline 2 & 4 & $3,8 \%$ & 4 & $3,8 \%$ \\
\hline 3 & 10 & $9,5 \%$ & 12 & $11,4 \%$ \\
\hline 4 & 9 & $8,6 \%$ & 16 & $15,2 \%$ \\
\hline 5 & 16 & $15,2 \%$ & 25 & $23,8 \%$ \\
\hline
\end{tabular}

Fonte: Elaborado pelo autor 
A origem dos maquinários utilizados na propriedade aparece com maior frequência pela aquisição própria, sendo que 92,3\% (97) de ambos os grupos possuem equipamentos próprios e 35,2\% (37) dos entrevistados utilizam complementação de mecanização por meio da subcontratação, enquanto $57,1 \%$ (60) dos cafeicultores detêm os maquinários, porém não subcontratam. Os cafeicultores que verticalizam apresentam baixa tendência de compartilhamento de maquinários, pois 22,9\% (24) expressaram a menor nota para adoção dessa prática. Já para os subcontratantes esse número cai para 10,5\% (11). Portanto, é possível observar que a adoção de compartilhamento de maquinários ainda é incipiente na cultura, visto que a própria subcontratação per se é recente.

Novamente surge o cenário da complementação do uso da mecanização pelos maquinários próprios, pois $20 \%$ (21) dos cafeicultores apresentaram o uso dos serviços e valor de capital imobilizado em máquinas próprias acima do valor de $\mathrm{R} \$ 400.000,00$.

Ao apontar para a especificidade de ativos de capital humano, é ressaltado que os produtores que não adotam os contratos apontam como muito importante o treinamento dos motoristas das colheitadeiras (notas 4 e 5 em uma escala Likert de cinco pontos) com uma representatividade de 54,3\% (57), pois, como esperado, o cafeicultor adota a gestão interna do serviço para conservar os maquinários e manter o nível ótimo da colheita mecanizada, colhendo o pé de café por inteiro e sem danificar a lavoura. Esse cenário se repete quanto ao aspecto física dos maquinários, embora com menor magnitude.

Retomando a tecnologia das máquinas, 46,7\% (49) dos respondentes que verticalizam a transação apontam as notas 3, 4 e 5 de complexidade tecnológica para revisão e custos das manutenções.

Com base em Masten (2000), observa-se que a especificidade temporal é presente, já que $23,8 \%$ (25) dos subcontratantes colocam a possibilidade de perda de valor no atraso da colheita como alta (notas 4 e 5 em uma escala Likert de cinco pontos), contra 39\% (41) dos produtores que verticalizam a transação.

\subsubsection{Características das prestadoras de serviço: ambiente contratual e tecnológico.}

A caracterização das firmas em relação à especialização na prestação de serviços e o cenário que a rodeia são expostos na Tabela 9. 
Tabela 9 - Prestadoras de serviço, relação contratual e tecnologia.

\begin{tabular}{|c|c|c|c|c|}
\hline & \multicolumn{2}{|c|}{ Subcontrata } & \multicolumn{2}{|c|}{ Verticaliza } \\
\hline \multicolumn{5}{|c|}{ Qual a origem da prestadora de serviços mais próxima? } \\
\hline & Qtde & $\%$ & Qtde & $\%$ \\
\hline no município de minha propriedade & 30 & $28,6 \%$ & 33 & $31,4 \%$ \\
\hline no estado de minha propriedade & 4 & $3,8 \%$ & 10 & $9,5 \%$ \\
\hline fora do Estado de minha propriedade & 3 & $2,9 \%$ & 2 & $1,9 \%$ \\
\hline Não tenho conhecimento & 8 & $7,6 \%$ & 15 & $14,3 \%$ \\
\hline $\begin{array}{c}\text { Distância da prestadora de serviço mais próxima (média em } \\
\text { quilômetros) }\end{array}$ & \multicolumn{2}{|c|}{41,2} & \multicolumn{2}{|c|}{57,13} \\
\hline \multicolumn{5}{|c|}{ Grau de confiança na manutenção feita pelas prestadoras de serviço } \\
\hline Alto & 5 & $4,8 \%$ & 5 & $4,8 \%$ \\
\hline Médio & 30 & $28,6 \%$ & 38 & $36,2 \%$ \\
\hline Baixo & 10 & $9,5 \%$ & 17 & $16,2 \%$ \\
\hline \multicolumn{5}{|c|}{ Percepção de máxima importância na decisão de subcontratar* } \\
\hline Serviço mais ágil & 30 & $28,6 \%$ & 31 & $29,5 \%$ \\
\hline Reduz custos & 27 & $25,7 \%$ & 26 & $24,8 \%$ \\
\hline Evita imobilizar capital em equipamentos & 23 & $21,9 \%$ & 18 & $17,1 \%$ \\
\hline Melhor qualidade do serviço contratado & 11 & $10,5 \%$ & 18 & $17,1 \%$ \\
\hline Dificuldade de contratação de mão de obra própria & 23 & $21,9 \%$ & 17 & $16,2 \%$ \\
\hline Fiscalização do Ministério Público & 16 & $15,2 \%$ & 12 & $11,4 \%$ \\
\hline \multicolumn{5}{|c|}{ Já teve problema trabalhista? } \\
\hline Sim & 9 & $8,6 \%$ & 9 & $8,6 \%$ \\
\hline Não & 36 & $34,2 \%$ & 49 & $46,6 \%$ \\
\hline Não responderam & 0 & $0,0 \%$ & 2 & $1,9 \%$ \\
\hline \multicolumn{5}{|c|}{ Existência de termos de ajustamento de conduta na região da propriedade } \\
\hline $\operatorname{Sim}$ & 11 & $10,47 \%$ & 12 & $11,4 \%$ \\
\hline Não & 34 & $32,4 \%$ & 47 & $44,8 \%$ \\
\hline Não responderam & 0 & $0,0 \%$ & 1 & $0,9 \%$ \\
\hline \multicolumn{5}{|c|}{ Contrata outros serviços? } \\
\hline Sim & 11 & $10,5 \%$ & 17 & $16,2 \%$ \\
\hline Não & 34 & $32,4 \%$ & 42 & $40,0 \%$ \\
\hline Não responderam & 0 & $0,0 \%$ & 1 & $0,9 \%$ \\
\hline
\end{tabular}

Fonte: Elaborado pelo autor

* A variável não totaliza $100 \%$ da amostra e nem o percentual total dentro de cada grupo, pois os valores só consideram a nota máxima da escala likert.

A especificidade de ativos locacional aparece ao direcionar atenção à localização das prestadoras de serviço. Quando o produtor desconhece a localização da firma ou esta é localizada fora do estado da propriedade, nota-se que 16,2\% (17) dos cafeicultores verticalizam a transação, enquanto 10,5\% (11) subcontratam. A integração vertical também surge ao analisar a distância média em quilômetros $(\mathrm{km})$ entre a empresa e a propriedade, visto que o cenário dos subcontratantes aparece com uma distância de 41,2 km contra 57,13 $\mathrm{km}$ daqueles que internalizam a mecanização da colheita.

A confiança na manutenção e revisão realizada pelas prestadoras de serviço é questionável, pois, mesmo dentre aqueles que contratam a mecanização, apenas 4,8\% (5) 
classificaram como alta, embora o padrão encontrado em ambos os grupos seja similar e traga a confiança como um fator pouco impactante na decisão de subcontratar.

Como outros aspectos relevantes, obteve-se que alguns fatores representaram maior influência negativa quanto à subcontratação de serviços de colheita mecanizada. Com foco na nota máxima de importância pela opinião dos entrevistados foi possível observar que a agilidade na colheita apareceu com 58,1\% (61); a redução de custos com mão de obra com 50,5\% (53); a redução de imobilização do capital com 39\% (41); a qualidade do processo de colheita através da mecanização com 27,6\% (29); a dificuldade na contratação de mão de obra com 38,1\% (40); e a fiscalização do Ministério Público com 26,6\% (28).

Voltando a atenção para o ambiente contratual e para a variável de incerteza, nota-se que os cafeicultores que verticalizam a mecanização possuem menos problemas com processos judiciais da legislação trabalhista, sendo 46,6\% (49) deste grupo contra 34,2\% (36) dos produtores que subcontratam e não enfrentam tais processos. Esse cenário é semelhante ao se analisarem as variáveis de existência de Termo de Ajustamento de Conduta na região da propriedade e de utilização de outros tipos de contratos. A primeira métrica apresenta que $11,4 \%$ (12) dos cafeicultores que se localizam em uma região em que existe TAC verticalizam a transação, enquanto $32,4 \%$ (34) dos produtores que estão em uma região onde não existe o termo realizam a subcontratação. A segunda variável apresenta que 10,5\% (11) dos produtores subcontratantes realizam outras contratações também, contra 40\% (42) dos cafeicultores que verticalizam, mas não possuem outros contratos. Dessa forma, com base em Mascarin (2014) e Hermalin, Katz e Craswell (2007), pode-se observar a influência da incerteza via ambiente institucional e gestão contratual no recorte desta pesquisa.

\subsubsection{Considerações sobre as estatísticas descritivas.}

Com base na exposição dos resultados da estatística descritiva, obtém-se a apresentação da lógica das métricas (Subseção 3.1 e Quadro 3) que compõem o modelo econométrico que investiga os determinantes da subcontratação da mecanização agrícola na cafeicultura. Os resultados da regressão probit são apresentados na subseção seguinte.

\subsection{Modelo Econométrico}

Primeiramente foi construído um modelo de regressão probit para a análise da escolha do arranjo institucional na transação de colheita mecanizada pelo cafeicultor. Constatou-se que não há evidência de multicolinearidade entre as variáveis independentes e 
nem heterocedasticidade nos resíduos, porém, optou-se pelo modelo com correção de erros robustos. $^{21}$

Conforme já destacado na metodologia, o modelo analisado é composto ${ }^{22}$ pela variável dependente - subcontratação de mecanização agrícola na colheita (1) e adoção de mecanização via maquinários e serviço próprios $(0)$ - e pelas seguintes categorias teóricas e variáveis independentes: especificidade de ativos de capital humano (anos de experiência do condutor; escala de importância de treinamento do condutor); especificidade de ativos locacional (existência de prestadora de serviço na região; distância, em quilômetros, da prestadora de serviço mais próxima); especificidade de ativos físicos (valor imobilizado em máquinas específicas para cafeicultura); especificidade temporal (escala de percepção de perda de valor pelo atraso na colheita); incerteza (existência de termos de ajustamento de conduta na região da propriedade; existência de problema judicial trabalhista; adoção de outros contratos); path dependence (existência de tradição da família na cafeicultura ( $3^{\mathrm{a}}$ geração); tempo, em anos, na atividade de cafeicultura); variáveis de controle (existência de nível de escolaridade elevado ( $\geq$ Ensino Superior); tamanho da propriedade em hectares; tipologia de mão de obra na propriedade; percentual de cafés gourmet em relação a produção total).

A Tabela 10 apresenta um resumo com estatísticas básicas e descritivas das variáveis do modelo.

Tabela 10 - Estatística descritiva das variáveis do modelo

\begin{tabular}{cccccc}
\hline Variável & Obs & Média & Desvio-Padrão & Min & Max \\
\hline cont_mec & 105 & 0,4285714 & 0,4972452 & 0 & 1 \\
escolaridade & 105 & 0,447619 & 0,4996336 & 0 & 1 \\
hectares & 105 & 87,38095 & 185,1324 & 2 & 1160 \\
mao_obra & 105 & 1,790476 & 0,8400462 & 1 & 3 \\
perc_gourmet & 104 & 0,1480769 & 0,2445447 & 0 & 0,8 \\
trein_cond & 105 & 4,742857 & 0,5888152 & 2 & 5 \\
exp_moto & 105 & 2.695238 & 1.754795 & 0 & 10 \\
exist_prest & 105 & 0,7333333 & 0,4443376 & 0 & 1 \\
dist_prest & 104 & 50,24038 & 110,1837 & 0 & 600 \\
log_val_maqprop & 105 & 10,06386 & 5,1721 & 0 & 15,89495 \\
atra_colheita & 105 & 3,780952 & 1,263245 & 1 & 5 \\
exist_tac & 104 & 0,2211538 & 0,4170337 & 0 & 1 \\
prob_trab & 103 & 0,1747573 & 0,3816164 & 0 & 1 \\
out_cont & 104 & 0,2692308 & 0,4457081 & 0 & 1 \\
tradicao_fam & 105 & 0,3714286 & 0,4855042 & 0 & 1 \\
\hline
\end{tabular}

\footnotetext{
${ }^{21}$ Foi realizado o teste "Variation Inflation Factor" (VIF) para o teste de multicolinearidade (VIF $<10$ ) e os testes Breusch-Pagan / Cook- Weiserg para heterocedasticidade vide apêndice 3 deste documento.

${ }^{22} \mathrm{Um}$ glossário com as variáveis pesquisadas e as respectivas descrições é apresentado no apêndice 2.
} 


\section{temp_cafe}

$105 \quad 23,75238$

12,77225

2

60

Fonte: Elaborado pelo autor

Para efeito comparativo, elaborou-se a Tabela 11 com a apresentação dos resultados

de modo incremental. No modelo A, são expostos os dados encontrados a partir das variáveis de controle. Nos modelos seguintes (B a D) há a agregação das variáveis teóricas de especificidade de ativos, incerteza e path dependence.

Tabela 11 - Modelos incrementais da regressão probit com erros robustos

\begin{tabular}{|c|c|c|c|c|}
\hline \multirow[t]{3}{*}{$\begin{array}{l}\text { Variável dependente } \\
\text { cont_mec }\end{array}$} & \multicolumn{4}{|c|}{$\begin{array}{c}1=\text { subcontratação de serviços de colheita mecanizada } \\
0=\text { uso de serviços próprios (máquina e empregado) }\end{array}$} \\
\hline & Modelos Probi & m correção po & os robustos de & na incremental \\
\hline & $\mathrm{A}$ & $\mathrm{B}$ & $\mathrm{C}$ & $\mathrm{D}$ \\
\hline escolaridade & $\begin{array}{c}0,860158^{* * *} \\
(0,3269167)\end{array}$ & $\begin{array}{l}0,7697873^{*} \\
(0,4295236)\end{array}$ & $\begin{array}{c}1,361012 * * * \\
(0,4500213)\end{array}$ & $\begin{array}{l}1,877423 * * * * \\
(0,5295506)\end{array}$ \\
\hline hectares & $\begin{array}{c}-0,0031283^{* * *} \\
(0,0011108)\end{array}$ & $\begin{array}{c}-0,004091 * * * \\
(0,0012699)\end{array}$ & $\begin{array}{c}-0,0049898 * * * * \\
(0,001371) \\
\end{array}$ & $\begin{array}{c}-0,0053918 * * * * \\
(0,0014967) \\
\end{array}$ \\
\hline mao_obra & $\begin{array}{c}-0,9530112^{* * * *} \\
(0,1822731)\end{array}$ & $\begin{array}{c}-0,7929665^{* * *} \\
(0,284833)\end{array}$ & $\begin{array}{r}-1,02925^{* * *} \\
(0,3405358)\end{array}$ & $\begin{array}{c}-1,151986^{* * *} \\
(0,4311868)\end{array}$ \\
\hline perc_gourmet & $\begin{array}{c}-0,4115334^{\mathrm{NS}} \\
(0,6120936)\end{array}$ & $\begin{array}{c}-0,4259199^{\mathrm{NS}} \\
(0,69683)\end{array}$ & $\begin{array}{c}-0,5971315^{\mathrm{NS}} \\
(0,7104125)\end{array}$ & $\begin{array}{l}-1,279375^{*} \\
(0,7389933)\end{array}$ \\
\hline trein_cond & & $\begin{array}{l}0,2817679^{\mathrm{NS}} \\
(0,2893532)\end{array}$ & $\begin{array}{l}0,4567159^{\mathrm{NS}} \\
(0,3210895)\end{array}$ & $\begin{array}{l}0,3787929^{\mathrm{NS}} \\
(0,3222173)\end{array}$ \\
\hline exp_moto & & $\begin{array}{l}-0,5674558 * * * * \\
(0,1508671)\end{array}$ & $\begin{array}{l}-0,6501894 * * * * \\
(0,1761673)\end{array}$ & $\begin{array}{c}-0,8187704 * * * \\
(0,2530336)\end{array}$ \\
\hline exist_prest & & $\begin{array}{c}-0,1422537^{\mathrm{NS}} \\
(0,3737092)\end{array}$ & $\begin{array}{c}-0,3218772^{\mathrm{NS}} \\
(0,472818)\end{array}$ & $\begin{array}{c}-0,3534104^{\mathrm{NS}} \\
(0,5463152)\end{array}$ \\
\hline dist_prest & & $\begin{array}{c}-0,0004335^{\mathrm{NS}} \\
(0,0013595)\end{array}$ & $\begin{array}{c}-0,0003523^{\mathrm{NS}} \\
(0,0016648)\end{array}$ & $\begin{array}{l}-0,001436^{\mathrm{NS}} \\
(0,0020574)\end{array}$ \\
\hline log_val_maqprop & & $\begin{array}{c}0,2105818^{* * *} \\
(0,0766268)\end{array}$ & $\begin{array}{c}0,2589756^{* * *} \\
(0,0800915)\end{array}$ & $\begin{array}{c}0,3351083 * * * * \\
(0,0914593)\end{array}$ \\
\hline atra_colheita & & $\begin{array}{c}-0,2463278^{*} \\
(0,1434641) \\
\end{array}$ & $\begin{array}{c}-0,3240412^{* *} \\
(0,1611737)\end{array}$ & $\begin{array}{c}-0,3083747^{*} \\
(0,1867566) \\
\end{array}$ \\
\hline exist_tac & & & $\begin{array}{c}-0,9307705^{* *} \\
(0,4168441)\end{array}$ & $\begin{array}{c}-1,330273^{* * *} \\
(0,4977225)\end{array}$ \\
\hline prob_trab & & & $\begin{array}{c}-0,1685882^{\mathrm{NS}} \\
(0,6800922)\end{array}$ & $\begin{array}{c}0,5978889^{\mathrm{NS}} \\
(0,82946)\end{array}$ \\
\hline out_cont & & & $\begin{array}{c}0,7275881^{\mathrm{NS}} \\
(0,55626)\end{array}$ & $\begin{array}{c}1,057064^{*} \\
(0,6202775)\end{array}$ \\
\hline tradicao_fam & & & & $\begin{array}{c}-1,576367^{* * *} \\
(0,4934657)\end{array}$ \\
\hline temp_cafe & & & & $\begin{array}{c}-0,0157878^{\mathrm{NS}} \\
(0,0184781)\end{array}$ \\
\hline Constante & $\begin{array}{l}1,3736 * * * * \\
(0,3936778)\end{array}$ & $\begin{array}{c}-0,0722283^{\mathrm{NS}} \\
(1,578245)\end{array}$ & $\begin{array}{c}-0,5944175^{\mathrm{NS}} \\
(1,651)\end{array}$ & $\begin{array}{c}0,1785578^{\mathrm{NS}} \\
(1,713184)\end{array}$ \\
\hline $\mathrm{N}^{0}$ observações & 104 & 103 & 101 & 101 \\
\hline Log-likehood & $-51,525911$ & $-36,037203$ & $-32,27187$ & $-27,474126$ \\
\hline LR-chi2 & 33,66 & 32,13 & 37,04 & 34,79 \\
\hline Prob $>$ chi 2 & 0,0000 & 0,0004 & 0,0004 & 0,0026 \\
\hline Pseudo-R2 & 0,2757 & 0,4894 & 0,5350 & 0,6042 \\
\hline
\end{tabular}

NS não significativa, ${ }^{*} \mathrm{p}<0,1, * * \mathrm{p}<0,05, * * * \mathrm{p}<0,01, * * * * \mathrm{p}<0,001$

Erro padrão entre parênteses

Fonte: Elaborado pelo autor 
O modelo utilizado nas análises é a regressão D. Neste modelo, as variáveis testadas estão relacionadas a todas as hipóteses e ao problema de pesquisa, o que não ocorre nos modelos anteriores, os quais possuem a função de apresentar a interação das variáveis. $\mathrm{O}$ modelo D apresentou boas estimações de acordo com sua estrutura: i) log likehood de -27.40; ii) Likehood ratio (LR) chi-square com 14 graus de liberdade igual a 34,97; iii) probabilidade do chi-square igual a 0,0025 , isto é, a hipótese nula de que todos os coeficientes do modelo proposto é rejeitada com $1 \%$ de significância.

Considerando o menor grau de significância, todas as hipóteses $\left(\mathrm{H}_{1}, \mathrm{H}_{2}\right.$ e $\left.\mathrm{H}_{3}\right)$ foram validadas com nível de $0,1 \%, 1 \%$ e $1 \%$, respectivamente. Dentro do grupo de cada hipótese foi possível observar os níveis de significância de $0,1 \%, 1 \%$ e $10 \%$ para $\mathrm{H}_{1} ; 1 \%$ e $10 \%$ para $\mathrm{H}_{2} ; 1 \%$ para $\mathrm{H}_{3}$; e $0,1 \%$, $1 \%$ e $10 \%$ para as variáveis de controle.

Observou-se que as variáveis com $0,1 \%$ de significância $(p<0,001)$ foram: ESCOLARIDADE, HECTARES e LOG_VAL_MAQPPROP. Com 1\% de significância $(p<0,01)$ surgiram: MAO_OBRA, EXP_MOTO, EXIST_TAC e TRADICA_FAM. Com 10\% de significância $(p<0,1)$ foram obtidas as variáveis: PERC_GOURMET, ATRA_COLHEITA e OUT_CONT. As variáveis que não apresentaram significância foram: TREIN_COND, EXIST_PREST, DIST_PREST, PROB_TRAB e TEMP_CAFE.

Ao retomar a Hipótese $1\left(\mathrm{H}_{1}\right)$, é possível observar que as variáveis EXP_MOTO $(p<0,01)$ e ATRA_COLHEITA $(p<0,1)$ afetam negativamente a subcontratação e tendem à integração vertical, com seus respectivos níveis de significância expostos entre parênteses. $\mathrm{O}$ resultado corrobora o esperado, ou seja, quanto maior a especificidade de ativos envolvida na transação de colheita mecanizada, maior seria a tendência de adoção de maquinário próprio (integração vertical). Posto isso, as variáveis que representam a especificidade de capital humano e temporal nesta transação são respectivamente a experiência do condutor e a percepção de perda de valor em caso de atraso da colheita.

A variável LOG_VAL_MAQPPROP apresentou sinal oposto ao esperado, porém significante. Possivelmente, tal resultado relaciona-se com o fato de que os respondentes consideraram os investimentos de modo geral, não apenas aqueles específicos para a colheita do café. O argumento baseia-se na variável PERC_GOURMET, ou seja, o cafeicultor que realiza a subcontratação pode perder qualidade de sua produção devido à falta de cuidado das prestadoras de serviço na colheita dos grãos mais maduros. Dessa forma, os produtores que realizam a subcontratação buscam outro meio de aumentar a qualidade dos grãos ainda 
imaturos, tal como os investimentos em equipamentos de pós-colheita, que podem alcançar valores tão elevados quanto os investimentos em maquinários de colheita.

O resultado da TREIN_COND foi oposto ao esperado e não significante. Sugere-se que o dado obtido é devido aos incentivos da firma prestadora em manter o empregado capacitado de magnitude serem semelhantes aos incentivos do cafeicultor. Diferentemente do proposto pela nota de rodapé $n^{0} 7$ da subseção 3.1, a preocupação com as perdas pela má regulação das máquinas e com a tentativa de evitar danos na lavoura está interligada à experiência do condutor. O resultado da variável EXP_MOTO corrobora esse argumento. $\mathrm{O}$ conhecimento tácito do condutor carrega a solução dos anseios do cafeicultor, visto que o empregado terá condições de minimizar tais perdas conforme maior conhecimento do cafezal em que se está operando (ex: altura das árvores ou distanciamento entre elas).

As variáveis EXIST_PREST e DIST_PREST apresentaram o sinal esperado, porém foram não significantes. O resultado encontrado sugere que ambos os fatores podem não interferir na decisão de subcontratar ou verticalizar a transação de colheita mecanizada, pois nota-se uma estratégia de amplificação de área de atendimento das prestadoras de serviço ao longo do território brasileiro. As firmas especializadas passaram a se movimentar nas regiões produtoras de café no período da colheita. Dessa forma, os investimentos de transporte das máquinas passaram a ser compensados pelos volumes de operação, visto que as prestadoras se movimentam em direção a regiões com um número razoável de propriedades que demandam o serviço; logo, a receita gerada pela quantidade de operações realizadas é maior do que o custo de transporte, o que faz com que a disponibilidade do serviço não seja influenciada pela localização do cafezal em si.

Quanto à Hipótese $2\left(\mathrm{H}_{2}\right)$, nota-se que a variável EXIST_TAC $(\mathrm{p}<0,01)$ afeta negativamente a subcontratação e tende à integração vertical, enquanto a variável OUT_CONT $(\mathrm{P}<0,1)$ direciona a decisão para a subcontratação. Ambos os resultados ocorreram como esperado. O primeiro mostra que há maior incerteza nas regiões em que houve atuação do Ministério Público proibindo a subcontratação de mecanização da colheita por meio do TAC, o que implica a integração vertical dessa transação. E o segundo resultado demonstra que a menor incerteza a partir da competência de lidar com gestão contratual (ex: resolução de conflitos, capacidade de negociação) implica a subcontratação.

A variável PROB_TRAB de $\mathrm{H}_{2}$ surgiu com sinal oposto ao esperado e não significante. A possível justificativa se dá pelo fato de que a existência dos problemas trabalhistas na cultura cafeeira é frequente há muitos anos. 
Os produtores de café estão cientes da atuação e da existência do ambiente institucional sobre este tema. Os conflitos quanto a processos para garantir os direitos do trabalhador iniciaram-se desde a introdução da produção do café no Brasil ${ }^{23}$, por isso o contato constante com problemas com direitos trabalhistas dos empregados torna a incerteza menos relevante para essa transação.

A respeito da Hipótese $3\left(\mathrm{H}_{3}\right)$, pode-se considerar que o resultado da variável TRADICAO_FAM $(p<0,01)$ comprova a tradição da família como relevante. O envolvimento na atividade ao longo das gerações carrega o aspecto de conservadorismo e path dependence nas tomadas de decisões. Esses fatores influenciam a favor do uso das máquinas próprias.

Entretanto, a variável TEMP_CAFE de $\mathrm{H}_{3}$ surgiu com o sinal esperado, mas não significante. Possivelmente, esse resultado indica que o path dependence exige um longo período de tempo para ser formado, bem como sugere que o conservadorismo intrínseco na tradição na atividade também só pode ser construído em longo prazo, visto que o tempo de contato com a cafeicultura de apenas um indivíduo não é suficiente.

No conjunto das variáveis de controle, todas obtiveram significância no modelo: ESCOLARIDADE $(p<0,001)$, HECTARES $(p<0,001)$, MAO_OBRA $\quad(p<0,01) \quad$ e PERC_GOURMET $(p<0,1)$. A variável ESCOLARIDADE mostrou que o aumento do nível de escolaridade influencia positivamente a subcontratação da mecanização da colheita, visto que a gestão financeira será mais robusta e a capacidade do produtor para lidar com este arranjo é potencializada; logo, o conservadorismo advindo do path dependence pode ser minimizado.

A variável HECTARES surgiu como esperado. A expectativa sobre essa métrica era a influência negativa na subcontratação, pois quanto maior a produção, maior será a possibilidade de diluição de custos fixos de capital imobilizado devido à escala da operação. O cafeicultor de maior porte tenderá a utilizar os maquinários de sua própria propriedade pela relação de custo-benefício. A necessidade de uma prestação de serviço em um cafezal com maior área eleva das despesas, visto que haverá necessidade de subcontratar mais horas de serviço.

A variável MAO_OBRA teve seu resultado diferente do esperado. A escala da variável de mão de obra (MAO_OBRA) deveria afetar positivamente a subcontratação, pois a estrutura própria de mão de obra adotada em uma propriedade que tende à característica de manual (maior a escala) teria que realizar maiores investimentos para adotar a colheita

\footnotetext{
${ }^{23}$ Ressalta-se que o posicionamento aqui tomado é referente aos processos judiciais relacionados diretamente ao contrato de trabalho, diferente do prisma dos processos quanto à subcontratação de mecanização da colheita.
} 
mecanizada via maquinários próprios. Porém, o resultado de correlação negativa com subcontratação sugere que o obstáculo não seja o aporte ou o acesso a capital, mas sim a inexistência de prestação de serviços naquela região.

A variável PERC_GOURMET apresentou correlação negativa com a subcontratação, conforme esperado. Esse resultado indica que o cafeicultor que participa do subsistema de cafés de alta qualidade tende a integrar verticalmente a mecanização, pois a colheita dos grãos é um processo sensível quanto ao uso da mecanização. Essa sensibilidade indica que é possível produzir qualidade com colheita mecanizada, porém com alguns cuidados. A qualidade, à luz do processo da colheita, relaciona-se ao nível de maturação do grão. Ao realizar a colheita via maquinários é necessário, por exemplo, realizar a regulagem da velocidade das hastes do equipamento ou até utilizar a máquina mais de uma vez nos mesmos pés para que ela colha apenas grãos maduros. Tal cenário é ignorado por algumas prestadoras de serviço, pois há aumento de custos ao adotar essa cautela na colheita e os ganhos de qualidade são capturados exclusivamente pelo cafeicultor, logo, ao visar à qualidade, o produtor integra verticalmente essa transação.

Quadro 7 - Resumo descritivo dos resultados

\begin{tabular}{|c|c|c|c|c|}
\hline Hipótese & Variável & Esperado & Resultado & Significância \\
\hline \multirow{6}{*}{$\mathbf{H}_{1}$} & TREIN_COND & - & + & Não significante \\
\hline & ЕХР МОТО & - & - & $p<0,01$ \\
\hline & EXIST_PREST & - & - & Não significante \\
\hline & DIST_PREST & - & - & Não significante \\
\hline & LOG_VAL_MAQPROP & - & + & $p<0,001$ \\
\hline & ATRA_COLHEITA & - & - & $p<0,1$ \\
\hline \multirow{3}{*}{$\mathbf{H}_{2}$} & EXIST_TAC & - & - & $p<0,01$ \\
\hline & PROB_TRAB & - & + & Não significante \\
\hline & OUT_CONT & + & + & $p<0,1$ \\
\hline \multirow[t]{2}{*}{$\mathbf{H}_{3}$} & TRADICAO_FAM & - & - & $p<0,05$ \\
\hline & TEMP_CAFE & - & - & Não significante \\
\hline \multirow{4}{*}{$\begin{array}{c}\text { Variáveis } \\
\text { de } \\
\text { controle }\end{array}$} & ESCOLARIDADE & + & + & $p<0,001$ \\
\hline & HECTARES & - & - & $p<0,001$ \\
\hline & MAO_OBRA & + & - & $p<0,01$ \\
\hline & PERC GOURMET & - & - & $p<0,1$ \\
\hline
\end{tabular}

Fonte: Elaborado pelo autor.

\subsubsection{Considerações sobre a análise econométrica}

Com base na pergunta de pesquisa, a análise levantou que os determinantes da subcontratação de colheita mecanizada na cafeicultura são o nível de escolaridade elevado e a 
adoção de contratos como forma de coordenação de outras transações. Já com direcionamento à integração vertical apareceram as variáveis de necessidade de experiência do condutor, percepção do produtor sobre a perda de valor devido ao atraso na colheita, existência de termo de ajustamento de conduta, tradição da família na cafeicultura, tamanho da propriedade $\left(\mathrm{n}^{\mathrm{o}} \mathrm{de}\right.$ hectares do cafezal) e capacidade de produzir café de alta qualidade.

Desta forma, a próxima e última seção apresenta as considerações acerca de cada um dos objetivos específicos da dissertação. Contribuições teóricas, apontamentos com a sobreposição na realidade dos negócios e as limitações são utilizados como os tópicos finais e conclusão da pesquisa. 


\section{CONSIDERAÇÕES FINAIS}

As considerações finais acerca da investigação são expostas por objetivos específicos, os quais foram todos alcançados.

O recorte sobre o objetivo " $i$ " trouxe a heterogeneidade ao longo do Sistema Agroindustrial do Café. O sistema apresentou as indústrias de insumos com estruturas de mercado altamente concentradas, líderes multinacionais, ambiente tecnológico dinâmico e o retrato do cafeicultor como tomador de preço. De modo diverso, as transações à jusante com a indústria de processamento e distribuição apresentaram líderes de mercado menos concentrados, segmentação por público-alvo (ex: qualidade) e práticas de formação de preço a partir das tecnologias produtivas e do produto em si. Com foco microanalítico, encontrou-se a diversidade de mecanismos de coordenação em todas as transações. Observaram-se transações com níveis distintos de frequência, com incerteza variando nas tipologias (institucional, mercado e tecnológica), assim como a presença das diferentes naturezas de especificidades de ativos. Com base no comparativo com os trabalhos de Zylbersztajn et al. (1993) e Saes e Farina (1999) notou-se a criação de estruturas de governança diferenciadas nesses últimos 20 anos.

Os resultados do objetivo " $i$ " trouxeram à tona particularidades relevantes no suporte organizacional dos institutos de pesquisa, as organizações com objetivos financeiros e organizações de ação coletiva. A seção revelou linhas de crédito disponíveis para capacitação de recursos para aquisição de maquinários agrícolas; organizações coletivas (leia-se sindicatos e associações) influentes na decisão de subcontratação de mecanização da colheita pela interferência política via lobby; um breve discorrer sobre a atuação das entidades de pesquisa e o desenvolvimento das tecnologias ao longo do tempo. Além disso, no âmbito institucional, o capítulo exibiu divergências nas decisões institucionais na esfera da terceirização. A contradição nas deliberações ocorreu via debate entre a atual referência institucional da Súmula 331 do TST e do PL 4330/2004, sendo a influência das diretrizes políticas dos partidos uma possível fonte de explicação dessa divergência. Como conclusão, a pesquisa aponta que o movimento sindical parece realçar a questão política e não uma preocupação social do emprego por parâmetros técnicos, visto que tais agentes enfatizam a proteção do trabalhador ao adotarem a postura contrária à terceirização dos serviços, porém em situações de subcontratação de serviços o trabalhador continuará a exercer a sua atividade seja como 
empregado na propriedade ou da firma prestadora do serviço, ocorrendo apenas a mudança da hierarquia e não dos direitos trabalhistas.

Os resultados do objetivo "iii" resgataram o anseio principal do trabalho a partir da análise econométrica da decisão de subcontratar ou integrar a transação de colheita mecanizada na cafeicultura. Pode-se dizer que o objetivo de analisar a subcontratação de mecanização da colheita foi alcançado em conjunto com a exposição de seus determinantes. De ordem teórica, obteve-se a comprovação empírica e validação das hipóteses de especificidade de ativos e incerteza do alinhamento eficiente da teoria da Economia de Custos de Transação, bem como a validação do path dependence.

Para a aplicação na realidade dos negócios do setor foram obtidos pontos estratégicos para o cafeicultor e para as firmas prestadoras do serviço. Observou-se que as características que contrariaram a subcontratação foram a necessidade de experiência do condutor, a percepção do produtor sobre a perda de valor devido ao atraso na colheita, a existência de Termo de Ajustamento de Conduta, o tamanho da propriedade ( $\mathrm{n}^{\mathrm{o}}$ de hectares do cafezal), a tradição da família na cafeicultura e a capacidade de produzir café de alta qualidade. Por outro lado, os determinantes da subcontratação foram o nível de nível de escolaridade elevado e a adoção de contratos como forma de coordenação de outras transações.

Os resultados deste estudo levantaram que o produtor desta atividade é apto a utilizar a mecanização da colheita por meio de três cenários: uso exclusivo de máquinas próprias, uso exclusivo de subcontratação ou uso de máquinas próprias e subcontratação de serviços juntos. A decisão de qual cenário adotar depende da realidade e características de cada propriedade. É possível afirmar que a transação de colheita mecanizada do cafeicultor foi alterada e, provavelmente, continua em constante mudança. A ótica generalista do produtor conservador pode ser tomada como extinta, visto que diversos agentes estão aptos para uso de subcontratação e outros mecanismos de coordenação oferecidos pelo setor.

A principal contribuição gerencial e de políticas públicas é que a subcontratação de mecanização agrícola da colheita pode ser vista como um arranjo institucional legal, e não uma forma de precarização do trabalho, como é apontado em alguns meios de comunicação. Especificamente, chama-se a atenção para a interferência política nas decisões referentes à terceirização, o que pode limitar a escolha do agente produtivo e afetar seu desempenho econômico. Assim, os esforços dos tomadores de decisão política devem ser direcionados para a normatização de mecanismos de monitoramento e controle das relações trabalhistas como um todo, sejam terceirizadas ou não. 
O levantamento realizado pode auxiliar os agentes do ambiente institucional na criação de normativas para a legislação ainda em fechamento, visando assim, à diminuição de potenciais conflitos, como os já existentes e mais frequentes em outras culturas a exemplo da soja e cana-de-açúcar.

A limitação da pesquisa é exposta pela falta da avaliação da fronteira de eficiência dos limites de adotar os arranjos institucionais de subcontratar, integrar verticalmente ou ambos. Ao mesmo tempo, essa lente é tida como sugestão para aprofundamento no tema. Simular a fronteira da firma nessa unidade de análise constitui, sem dúvida, num instigante problema de pesquisa teórico e empírico. 


\section{REFERÊNCIAS BIBLIOGRÁFICAS}

Allen, D. W., \& Lueck, D. (2002). The Nature of the Farm: Contracts, Risk, and Organization in Agriculture. Cambridge, Mass: MIT Press.

Associação Brasileira da Indústria de Café. (2015). Indicadores da indústria de café no Brasil - $2015 . \quad$ Retrieved from http://www.abic.com.br/publique/cgi/cgilua.exe/sys/start.htm?sid=61\#1910

Associação Brasileira da Indústria de Café Solúvel. (2017a). A entidade. Retrieved from http://www.abics.com.br/

Associação Brasileira da Indústria de Café Solúvel. (2017b). Relatório do café solúvel no Brasil - Fev/2017. Retrieved from http://www.abics.com.br/relatorio-do-cafe-soluvel-dobrasil-fev2017/

Associação Brasileira de Atacadistas e Distribuidores. (2015). Ranking ABAD. Retrieved from http://www.abad.com.br/ds_ranking.php

Associação Brasileira de Máquinas e Equipamentos. (2016). Café ganha força como moeda de troca na compra de máquinas e implementos. Retrieved from http://sfagro.uol.com.br/cafeganha-forca-como-moeda-de-troca-na-agrishow-2016/

Associação Nacional dos Fabricantes de Veículos Automotores. (2014). Anuário da Indústria Automobilística Brasileira. Retrieved from http://www.anfavea.com.br/anuario.html

Associação Nacional para Difusão de Adubos. (2015a). Anuário Estatístico de 2015. São Paulo, SP: Autor.

Associação Nacional para Difusão de Adubos. (2015b). Principais indicadores do setor de fertilizantes. Retrieved from http://anda.org.br/index.php?mpg=03.00.00\&ver=por

Banco Central do Brasil. (2013). 50 maiores bancos e o consolidado do Sistema Financeiro Nacional. Retrieved from http://www4.bcb.gov.br/top50/port/top50.asp

Banco Central do Brasil. (2016). Resolução no 4.472, de 31 de março de 2016. Ajusta normas de financiamento com recursos do Fundo de Defesa da Economia Cafeeira (Funcafé). Retrieved from http://www.bcb.gov.br/pre/normativos/busca/downloadNormativo.asp?arquivo=/Lists/No rmativos/Attachments/50175/Res_4472_v1_O.pdf

Banco Nacional de Desenvolvimento Econômico e Social. (2011). BNDES Finame Agrícola.

Retrieved from http://www.bndes.gov.br/wps/portal/site/home/financiamento/produto/bndes-finameagricola/!ut/p/z1/04_iU1DgAgL9CCADyIQSuGj9qLzEssz0xJLM_LzEHP0I_cgos3gvCx 9nD0sTAx93o2AzĀ8eAQENjj6BQI4tQU30vsEaEfmRCPwq_3gioXqhyHJRpFGRr7Nvun5UQWJJhm5mXlq-fkRSXkpqsW5aZ15ibqpuYnpRZnJ-TqJQXZUJACSpPMs/ 
Banco Nacional de Desenvolvimento Econômico e Social. (2012a). A indústria de defensivos agrícolas. BNDES Setorial 35, 233-276. Retrieved from http://www.bndes.gov.br/SiteBNDES/export/sites/default/bndes_pt/Galerias/Arquivos/co nhecimento/bnset/set3507.pdf

Banco Nacional de Desenvolvimento Econômico e Social. (2012b). A indústria química e o setor de fertilizantes. Retrieved from http://www.bndes.gov.br/SiteBNDES/bndes/bndes_pt/Galerias/Convivencia/Publicacoes/ Consulta_Expressa/Tipo/BNDES_Setorial/201210_10.html

Banco Nacional de Desenvolvimento Econômico e Social. (2015). Moderfrota. Retrieved from http://www.bndes.gov.br/wps/portal/site/home/financiamento/produto/moderfrota

Brasil. (1989). Lei $n^{\circ} 7.802$ de 11 de julho de 1989. Presidência da República. Retrieved from http://www.planalto.gov.br/ccivil_03/leis/L7802.htm

Brasil. (1990). Lei $n^{o} 8.080$ de 19 de setembro de 1990. Presidência da República. Retrieved from http://www.planalto.gov.br/ccivil_03/leis/L8080.htm

Brasil. (1999). Lei $n^{\circ} 9.782$ de 26 de Janeiro de 1999. Presidência da República. Retrieved from http://www.planalto.gov.br/ccivil_03/leis/L9782.htm

Brasil. (2004). Projeto de lei $n^{o}$ 4330/2004. Presidência da República. Retrieved from http://www.camara.gov.br/proposicoesWeb/prop_mostrarintegra;jsessionid=DA3C6EFF AD49AF4C091D7C995CC1FCD6.proposicoesWeb2 codteor $=246979 \&$ filename $=\mathrm{PL}+4$ $330 / 2004$

Brazil Specialty Coffee Association. (2012). VALOR Especial Café: Falta de mão de obra favorece indústria de máquinas. Retrieved from http://bsca.com.br/noticia.php?id=140

Caleman, S. M. de Q., \& Zylbersztajn, D. (2012). Falta de garantias e falhas de coordenação: evidências do sistema agroindustrial da carne bovina. Revista de Economia E Sociologia Rural, 50(2), 223-241.

Calvin, L., \& Martin, P. (2012). The U.S. Produce industry: Labor-intensive commodities in a global market. American Journal of Agricultural Economics, 94(2), 471-476.

Canto, J. L., Machado, C. C., Gontijo, F. M., \& Jacovine, L. A. G. (2006). Colheita e transporte florestal em propriedades rurais fomentadas no estado do Espírito Santo. Revista Árvore, 30(6), 989-998.

Chaddad, F. (2014). BrasilAgro: Organizational architecture for a high-performance farming corporation. American Journal of Agricultural Economics, 96(2), 578-588.

Coase, R. H. (1937). The Nature of the Firm. Economica, 4(16), 386-405.

Coase, R. H. (1998). The New Institutional Economics. The American Economic Review, 88(2), 72-74. 
Coase, R. H. (1991). The Institutional Structure of Production. Nobel Prize Lecture to the Memory of Alfred Nobel.

Confederação Nacional dos Trabalhadores na Agricultura. (n.d.). A CONTAG. Retrieved from http://www.contag.org.br/index.php?modulo=portal\&acao=interna\&codpag=227\&nw=1

Conselho dos Exportadores de Café do Brasil. (2016). Exportações brasileiras. Retrieved from http://www.cecafe.com.br/dados-estatisticos/exportacoes-brasileiras/

Cook, M. L., \& Chaddad, F. R. (2000). Agroindustrialization of the global agrifood economy: Bridging development economics and agribusiness research. Agricultural Economics, 23(3), 207-218.

Cruz neto, F., \& Matiello, J. B. (1981). Estudo comparativo de rendimento de colheita entre cultivares Mundo Novo e Catuaí, em lavouras com diferentes níveis de produtividade. Paper presented at the Congresso Brasileiro de Pesquisas Cafeeiras, 9., São Lourenço, Rio de Janeiro, Brazil.

Davis, J. H., \& Goldberg, R. A. (1957). A concept of agribusiness. Boston: Division of Research, Graduate School of Business Administration, Harvard University.

Davis, L. E., \& North, D. C. (1971). Institutional Change and American Economic Growth. Cambridge: Cambridge University Press.

Empresa Brasileira de Pesquisa Agropecuária. (2012). Relatório de avaliação dos impactos das tecnologias geradas pela Embrapa. Retrieved from http://bs.sede.embrapa.br/2012/relatorios/instumentacao_2012_derricadeiracafe.pdf

Everylog. (2013, June 11). País cresce no mercado de defensivos [Web log post]. Retrieved from

http://www.everylog.com.br/EveryLog/Blog/Entradas/2013/6/11_Pais_cresce_no_merca do_de_defensivos.html

Farina, E. M. M. Q. (1999). Competitividade e coordenação de sistemas agroindustriais: um ensaio conceitual. Gestão \& Produção, 6(3), 147-161.

Federação dos Trabalhadores na agricultura do estado de Goiás (2005). Notícias. Retrieved from http://www.fetaeg.org.br/site.asp? secao=noticias

Ferreira, R. G., \& Ortega, A. C. (2004). Impactos da intensificação da mecanização da colheita de café nas microrregiões de Patos de minas e Patrocínio - MG. Teoria E Evidência Econômica, 12(23), 71-96.

Fisher, D. U., \& Knutson, R. D. (2013). Uniqueness of agricultural labor markets. American Journal of Agricultural Economics, 95(2), 463-469.

Fundação Procafé. (2013). Apresentação sobre mecanização no café. Retrieved from http://fundacaoprocafe.com.br/sites/default/files/publicacoes/pdf/1\%20-

$\% 20$ Evolu $\%$ C3\%A7\%C3\%A3o $\% 20$ da $\% 20$ colheita $\% 20$ mec $\%$ C3\%A2nica $\% 20$ do $\% 20$ caf $\% \mathrm{C} 3 \% \mathrm{~A} 9 \% 20 \mathrm{da} \% 20$ planta.pdf 
Goldberg, R. A. (1968). Agribusiness coordination: a systems approach to the wheat, soybean, and florida orange economies. Harvard University/Graduate School of Business and Administration/Division of Research.

Gujarati, D. (2006). Econometria Básica. (4th ed.) Rio de Janeiro: Campus Rio de Janeiro.

Guo, H., Jiz, C., Jin, S., \& Huang, Z. (2015). Outsourcing Agricultural Production: Evidence from Rice Farmers in Zhejiang Province. Paper presented at the AAEA \& WAEA Joint Annual Meeting, San Francisco, California.

Hendrikse, G. W. J., \& Veerman, C. P. (2001). Marketing cooperatives and financial structure: A transaction costs economics analysis. Agricultural Economics, 26(3), 205216.

Hermalin, B. E., Katz, A. W., \& Craswell, R. (2007) . Law \& economics of contracts. In A. M. Polinsky \& S. Shavell (Eds), Handbook of Law and Economics, v. 1. Amsterdam: NorthHolland.

Houssou, N., Diao, X., Cossar, F., Kolavalli, S., Jimah, K., \& Aboagye, P. O. (2013). Agricultural mechanization in Ghana: Is specialized agricultural mechanization service provision a viable business model? American Journal of Agricultural Economics, 95(5), 1237-1244.

Instituto Brasileiro de Executivos de Varejo e Mercado de Consumo. (2015). As 50 maiores varejistas do Brasil. Retrieved from http://exame.abril.com.br/negocios/as-50-maioresvarejistas-do-brasil/

Instituto Brasileiro de Geografia e Estatística. (2006). Censo Agropecuário 2006. Retrieved from http://www.ibge.gov.br/home/estatistica/economia/agropecuaria/censoagro

Instituto Brasileiro de Geografia e Estatística. (2009). Pesquisa de Orçamento Familiar (POF) 2008-2009.

Retrieved from http://www.ibge.gov.br/home/estatistica/populacao/condicaodevida/pof/2008_2009/

Instituto Brasileiro de Geografia e Estatística. (2014a). Pesquisa de Estoques. Retrieved from http://www.ibge.gov.br/home/estatistica/indicadores/agropecuaria/estoque

Instituto Brasileiro de Geografia e Estatística. (2014b). Pesquisa Industrial - Empresa 2014. Retrieved from http://biblioteca.ibge.gov.br/index.php/bibliotecacatalogo? view $=$ detalhes \&id $=71719$

Igata, M., Hendriksen, A., \& Heijman, W. J. M. (2008). Agricultural outsourcing: A comparison between the Netherlands and Japan. APSTRACT: Applied Studies in Agribusiness and Commerce, 2, 29-33.

Joskow, P. L. (1987). Contract Duration and Transactions Specific Investment: Empirical Evidence from Coal Markets. American Economic Review, 77(1), 168-185. 
Klein, B., Crawford, R. G., \& Alchian, A. (1978). Vertical Integration, Appropriable Rents, and the Competitive Contracting Process. The Journal of Law and Economics, 21(2), 297-326.

Lajili, K., Barry, P. J., Sonka, S. T., \& Mahoney, J. T. (1997). Farmers' preferences for crop contracts. Journal of Agricultural and Resource Economics, 22(2), 264-280.

Lajili, K., Madunic, M., \& Mahoney, J. T. (2007). Testing Organizational Economics Theories of Vertical Integration. Research Methodology in Strategy and Management, 4(7), 343-368.

Laurenti, A. C (2004). Terceirização na Produção Agrícola. Brasília: IAPAR, IPEA.

Lazzarini, S., Chaddad, F., \& Cook, M. (2001). Integrating supply chain and network analyses: the study of netchains. Journal on Chain and Network Analysis, 1(1), 7-22.

Lyons, B. R. (1994). Contracts and Specific Investment: An Empirical Test of Transaction Cost Theory. Journal of Economics \& Management Strategy, 3(2), 257-278.

Ministério da Agricultura, Pecuária e Abastecimento. (2003a). Lei $n^{\circ} 10.711$ de 05 de agosto de 2003 - Registro Nacional de Sementes e Mudas (RENASEM).

Ministério da Agricultura, Pecuária e Abastecimento. (2003b). Instrução normativa $n^{\circ} 8$ de 11 de junho de 2003. Regulamento Técnico de Identidade e de Qualidade para a Classificação do Café Beneficiado Grão Cru.

Ministério da Agricultura, Pecuária e Abastecimento. (2016a). Estatísticas. Retrieved from http://www.agricultura.gov.br/vegetal/estatisticas

Ministério da Agricultura, Pecuária e Abastecimento. (2016b). Agrofit. Retrieved from http://agrofit.agricultura.gov.br/agrofit_cons/principal_agrofit_cons

Ministério da Agricultura, Pecuária e Abastecimento. (2016c). Safras e Estoques. Retrieved from http://www.agricultura.gov.br/vegetal/safras-estoques

Martins, A. L. (2008). História do café. Editora Contexto.

Mascarin, A. L. C. (2014). Serviços de mecanização agrícola: atividade meio ou atividade fim?. (Master Dissertation, Faculdade de Economia, Administração e Contabilidade, Universidade de São Paulo, São Paulo, Brazil).

Masten, S. E. (2000). Transaction-cost economics and the organization of agricultural transactions. Industrial Organization (Advances in Applied Microeconomics). Emerald, 173-195.

Medeiros, L. S. (1989). História dos movimentos sociais no campo. Rio de Janeiro: FASE.

Miele, M., \& Zylbersztajn, D. (2005). Coordenação e desempenho da transação entre viticultores e vinícolas na serra Gaúcha. RAUSP - Revista de Administração, 40(4), 330341. 
Mizumoto, F. M., \& Zylbersztajn, D. (2006). A coordenação simultânea de diferentes canais como estratégia de distribuição adotada por empresas da avicultura de postura. Organizações Rurais \& Agroindustriais, 8(2), 147-159.

Morais, M. G. A. (2012). Colheita e transporte de mandeira: terceirização $x$ verticalização das operações. (Master Dissertation. Escola de Engenharia de São Carlos, Universidade de São Paulo, São Paulo, Brazil).

Ministério Público do Trabalho. (2005a). TERMO DE AJUSTE DE CONDUTA N." 094 /2005-CODIN-PRT-18a REGIAOO. Retrieved from http://mpt.gov.br/portaltransparencia/proxy.php?doc=aHR0cHM6Ly9tcHRkaWdpdGFsL nBydDE4Lm1wdC5tcC5ici9wcm9jZXNzb0VsZXRyb25pY28vZG9jdW1lbnRvcy9iYW1 4YXJfcHJvY2Vzc29fZWxldHJvbmljby5waHA\%2Fb3A9YmFpeGFyRG9jJmlkQXJxd W12bz0xMDAyODgyJmNvZGlnb0FjZXNzbz1SSjhWOEQ5U1c0OURLWVo0

Ministério Público do Trabalho. (2005b). TERMO DE AJUSTE DE CONDUTA N ${ }^{\circ}$ 008/2005CODIN-PRT - $18^{a}$ REGIÃO. Retrieved from http://mpt.gov.br/portaltransparencia/proxy.php?doc=aHR0cHM6Ly9tcHRkaWdpdGFsL nBydDE4Lm1wdC5tcC5ici9wcm9jZXNzb0VsZXRyb25pY28vZG9jdW1lbnRvcy9iYW1 4YXJfcHJvY2Vzc29fZWxldHJvbmljby5waHA\%2Fb3A9YmFpeGFyRG9jJmlkQXJxd W12bz02OTMzMjkmY29kaWdvQWNlc3NvPTIEMIJSNEZMRFZLR0YzQUU\%3D

Ministério Público do Trabalho. (2009). Ministério Público do Trabalho. TERMO DE COMPROMISSO DE AJUSTAMENTO DE CONDUTA $N^{\circ}$ 6877/2009. Retrieved from http://mpt.gov.br/portaltransparencia/proxy.php?doc=aHR0cHM6Ly9tcHRkaWdpdGFsL nBydDE1Lm1wdC5tcC5ici9wcm9jZXNzb0VsZXRyb25pY28vZG9jdW1lbnRvcy9iYW1 4YXJfcHJvY2Vzc29fZWxldHJvbmljby5waHA\%2Fb3A9YmFpeGFyRG9jJmlkQXJxd W12bz0zMzEzMiZjb2RpZ29BY2Vzc289TFJHNktDQ0dSQQ\%3D\%3D

Ministério Público do Trabalho. (2010a). TERMO DE COMPROMISSO N. 20100225 PTM/CALDAS NOVAS. Retrieved from http://mpt.gov.br/portaltransparencia/proxy.php?doc=aHR0cHM6Ly9tcHRkaWdpdGFsL nBydDE4Lm1wdC5tcC5ici9wcm9jZXNzb0VsZXRyb25pY28vZG9jdW1lbnRvcy9iYW1 4YXJfcHJvY2Vzc29fZWxldHJvbmljby5waHA\%2Fb3A9YmFpeGFyRG9jJmlkQXJxd W12bz01NDE3JmNvZGlnb0FjZXNzbz1TQ1pQQ1RQMzZS

Ministério Público do Trabalho. 2010b. TERMO DE AJUSTE DE CONDUTA N. ${ }^{\circ} 20100259$. Retrieved from http://mpt.gov.br/portaltransparencia/proxy.php?doc=aHR0cHM6Ly9tcHRkaWdpdGFsL nBydDE4Lm1wdC5tcC5ici9wcm9jZXNzb0VsZXRyb25pY28vZG9jdW1lbnRvcy9iYW1 4YXJfcHJvY2Vzc29fZWxldHJvbmljby5waHA\%2Fb3A9YmFpeGFyRG9jJmlkQXJxd W12bz01NDUwJmNvZGInb0FjZXNzbz1BVjhYMU5LUVRV

Navarro, A. L. (2002). La externalización del trabajo agrario y las empresas de servicios a la agricultur. Economía Agraria Y Recursos Naturales, 2(1), 45-67.

Neves, L. W. A. (2009). Fazer ou Comprar: uma análise sob a perspectiva das teorias da Economia dos Custos de Transação e da Visão Baseada nos Recursos. (Tese de Doutorado, Pontífica Universidade Católica, PUC-RIO, Rio de Janeiro, Brasil). 
Neves, M. F., \& Caleman, S. M. Q. (2015). Conceitos gerais, evolução e apresentação do Sistema agroindustrial. In D. Zylbersztajn, M. F. Neves, \& S. M. Q. Caleman (Org.), Gestão de Sistemas de Agronegócios (pp. 44-70). Atlas.

Neves, M. F. (2016, October 28). Numbers and trends of agricultural crop protection industry in Brazil. China Daily. Retrieved from http://www.chinadaily.com.cn/opinion/201610/28/content_27205343.htm

North, D. C. (1990). Institutions, Institutional Change and Economic Performance. Cambridge: Cambridge University. Press.

North, D. C. (1991). Institutions. Journal of Economic Perspectives, 5(1), 97-112.

Novais, R., \& Romero, E. A. (2009). Retorno econômico em função da terceirização dos serviços agrícolas ao nível de propriedade. Custos E @gronegócio on Line, 5(2), 133 146.

Nunes, R., Saes, M. S. M., Rossignolo, V. L. S., Souza, R. N. R. L., Souza, R. C. (2013). Incentives to differentiation strategies form Brazilian coffee producers. Revista de Economia e Administração (Impresso), 12 (2), 165-179.

Oliveira, G. M., Caleman, S. M. Q., Cunha, C. F., \& Zylbersztajn, D. (2014). Productive Systems of Animal Protein in Brazil: Characteristics of the Transactions between Producers and Processing Industries in the State of Mato Grosso Do Sul. Australian Journal of Basic and Applied Sciences, 8, 282-293.

Otsuka, K. (2012). Food Insecurity, Income Inequality, and the Changing Comparative Advantage in WorldAgriculture. Paper presented at the 27th International Conference of Agricultural Economists, Foz do Iguaçu, Brazil.

Reardon, T., \& Barrett, C. B. (2000). Agroindustrialization, globalization, and international development: An overview of issues, patterns, and determinants. Agricultural Economics, 23, 195-205.

Saes, M. S. M. (2000). Organizações e instituições. In D. Zylbersztajn \& M. F. Neves (Orgs.), Economia e Gestão dos Negócios Agroalimentares (pp. 65-186). Pioneira.

Saes, M. S. M., \& Farina, E. M. M. Q. (1999). O agribusiness do café no Brasil. São Paulo: Milkbizz.

Silva F. M., Salvador, N., \& Pádua, T. S. (2000). Café: mecanização da colheita. Paper presented at the Simpósio de Pesquisa dos Cafés do Brasil, Poços de Caldas, Goiás.

Silva, F. M., Salvador, N., Pádua, T. S., \& Queiroz, D. P. (2001). Colheita do café mecanizada e semimecanizada. Lavras: UFLA.

Simon, H. A. (1955). A Behavioral Model of Rational Choice. The Quarterly Journal of Economics, 69(1), 99-118. 
Takeshima, H., Nin-Pratt, A., \& Diao, X. (2013). Mechanization and agricultural technology evolution, agricultural intensification in Sub-Saharan Africa: Typology of agricultural mechanization in Nigeria. American Journal of Agricultural Economics, 95(5), 12301236.

Tieppo, R. C. (2015). Demanda de energia e custo operacional no planejamento de sistemas mecanizados na produção de grãos. (Doctoral Thesis, Escola Superior de Agricultura Luiz de Queiroz, Universidade de São Paulo, Piracicaba, Brazil).

Tribunal Superior do Trabalho. (2011). Súmula $n^{o}$ 331. Retrieved from http://www3.tst.jus.br/jurisprudencia/Sumulas_com_indice/Sumulas_Ind_301_350.html

Williamson, O. E. (1975). Markets and Hierarchies: Analysis and Antitrust Implications: a Study in the Economics of Internal Organization. Free Press.

Williamson, O. E. (1981). The Economics of Organization: The Transaction Cost Approach. American Journal of Sociology, 87(3), 548-577.

Williamson, O. E. (1983). Credible Commitments : Using Hostages to Support Exchange. The American Economic Review, 73(4), 519-540.

Williamson, O. E. (1985). The Economic Intstitutions of Capitalism. Free Press.

Williamson, O. E. (1991). Comparative Economic Organization: The Analysis of Discrete Structural Alternatives. Administrative Science Quarterly, 36(2), 269-296.

Williamson, O. E. (1996). The Mechanisms of Governance. Oxford University Press.

Williamson, O. E. (2005). The Economics of Governance. American Economic Review, 95(2), $1-18$.

Woolddridge, J. M. (2006). Introductory Econometrics: A Modern Approach. International Edition, Thomson.

Yang, J., Huang, Z., Zhang, X., \& Reardon, T. (2013). The rapid rise of cross-regional agricultural mechanization services in China. American Journal of Agricultural Economics, 95(5), 1245-1251.

Zanchet, M. S. (2009). A Terceirização Das Atividades Agrícolas No Sudoeste Paranaense. ANÁLISE CONJUNTURAL, 31(1), 18 - 20.

Zylbersztajn, D. (1995). Estruturas de Governança e Coordenação do Agribusiness: Uma aplicação da Nova Economia das Instituições. (Livre Docência, Faculdade de Economia, Administração e Contabilidade, Universidade de São Paulo, Piracicaba, Brazil).

Zylbersztajn, D. (1996). Governance structures and agribusiness coordination: a transaction cost economics based approach. In R. A. Goldberg (Ed.), Research in domestic and international agribusiness management (pp. 245-310). JAI Press Ltd. 
Zylbersztajn, D. (2000). Conceitos gerais, evolução e apresentação do Sistema agroindustrial. In D. Zylbersztajn \& M. F. Neves (Orgs.). Economia e Gestão dos Negócios Agroalimentares (pp. 1-23). Pioneira.

Zylbersztain, D., Farina, E. M. M. Q., \& Santos, R. C. (1993). O sistema agroindustrial do café: um estudo da organização do agrobusiness do café visto como a chave da competividade. Porto Alegre: Ortiz. 


\section{APÊNDICES}

APÊNDICE 1 - Instrumento de coleta de dados

Ao preencher esse questionário, você contribuirá para um estudo do grupo de pesquisa PENSA - Centro de Conhecimento em Agronegócios da Universidade de São Paulo.

Esperamos contar com a sua colaboração prestando as informações solicitadas.

Em caso de dúvidas, você poderá comunicar-se conosco pelo e-mail: gustavomoliv@gmail.com

Desde já, agradecemos a sua colaboração.

A equipe de pesquisa sobre cafés de qualidade.

As respostas serão confidenciais. O(A) SR.(A) E SUA EMPRESA NÃO SERÃO IDENTIFICADOS EM NENHUMA CIRCUNSTÂNCIA. Agradecemos pela sua colaboração. Sua experiência será de grande ajuda para nos aproximar dos problemas reais da cafeicultura brasileira

Horário de Início: __hr__min Identificação (nome do proprietário ou da propriedade rural):

A) PERFIL DO PRODUTOR

1. Localização (município/estado):

2. Escolaridade: ( ) Sem escolaridade ( ) Nível fundamental ( ) Nível Médio ( ) Nível Superior

2.1 Quantos anos de estudo no total? anos

3. Tempo na atividade de cafeicultura: anos

4. Qual a idade média de seu cafezal? anos

5. Como você classifica sua propriedade em relação ao relevo predominantemente:

Plana: $\%$

Montanhosa: $\%$

\begin{tabular}{|c|c|c|c|}
\cline { 2 - 4 } \multicolumn{1}{c|}{ 6. Caracterize a atividade } & $\begin{array}{c}\text { Produção } \\
\text { média em } \\
\text { cafeeira de sua }\end{array}$ & $\begin{array}{c}\text { Percentual na } \\
\text { renda }(\%)\end{array}$ \\
\hline propriedade. & $\begin{array}{c}\text { Área em } \\
\text { Hectares }\end{array}$ & & \multicolumn{1}{c|}{} \\
\hline Café & & & \\
\hline
\end{tabular}


6. Tradição na atividade: ( ) 1a geração ( ) $2^{\underline{a}}$ geração ( ) 3 ${ }^{\underline{a}}$ geração ( ) > $3^{\text {a }}$ geração

6.1 Quantos anos sua família está na cafeicultura? anos

7. É membro de cooperativa ou associação? ( ) Sim （） Não Há quantos anos?

B) CARACTERÍSTICAS DA PRODUÇÃo

8. Nos últimos 05 anos, CONTRATOU de serviços de mecanização agrícola de alguma empresa? ( ) Sim ( ) Não Se sim, quantas vezes? vezes

9. Classifique o tipo de tecnologia adotada nos tratos culturais e colheita PREDOMINANTE em sua propriedade:

( ) Mecanizado

( ) Semimecanizado

( ) Manual

10. Os MAQUINÁRIOS utilizados em sua lavoura são propriedade de (marcar apenas o predominante):

( ) Própria

( ) do trabalhador contratado

( ) Empresa prestadora de serviços

( ) Cooperativa

( ) Associação

( ) Vizinhos

( ) Não possuo maquinários

11. Existem grupos de cafeicultores que compram e compartilham maquinários agrícolas em sua região? ( ) Sim

( ) Não

12. Qual a sua tendência de compartilhar máquinas com produtores de sua região? Dê uma nota de [5] ALTA TENDÊNCIA a [1] BAIXA TENDÊNCIA:

13. Qual o valor aproximado do capital imobilizado nos maquinários próprios?

( ) Até R $\$ 50.000,00$

（ ) De R\$50.000,01 a R\$100.000,00

( ) De $\mathrm{R} \$ 100.000,01$ a $\mathrm{R} \$ 200.000,00$

( ) De R\$200.000,01 a R \$300.000,00

( ) De R\$300.000,01 a R \$ 400.000,00

( ) Mais que $R \$ 400.000,00$

( ) Não possuo maquinários 
14. Qual o valor, em reais, do capital imobilizado nos maquinários próprios? $\mathrm{R} \$$ reais

15. Você usa as máquinas de colheita do café para também colher outras culturas? Dê uma nota de [5] SEMPRE USO a [1] NUNCA USO:

16. Quantos anos de experiência um motorista deve ter para conseguir conduzir os maquinários de modo eficiente? anos

17. Qual a necessidade de treinamento do operador dos maquinários de colheita do café?

Dê uma nota de [5] MUITO NECESSÁRIO a [1] DESNECESSÁRIO:

18. Como é a manutenção (revisões) de suas máquinas?

Dê uma nota de [5] DIFÍCIL E CUSTOSA a [1] FÁCIL E BARATA:

19. Quanto às manutenções realizadas pelas prestadoras de serviços de mecanização agrícolas, qual o seu grau de confiança nesta ação realizada pela empresa nos maquinários dela? ( ) Alto ( ) Médio ( ) Baixo

20. A qualidade no café é afetada pelo atraso na colheita do café? Dê uma nota de [5] MUITO AFETADA a [1] POUCO AFETADA:

21. Qual o período de mudança tecnológica que o seu maquinário fica ultrapassado? ( ) 1 ano $\quad$ ( ) 2 a 5 anos $\quad$ ( ) Mais que 5 anos

22. Qual o valor, em reais, contratado em programas de financiamento agrícola governamental para aquisição de máquinas para sua principal propriedade? (Caso não contrate, responda ZERO). $R \$$ reais

23. Quantos contratos de prestações de serviços na atividade cafeeira foram firmados anteriormente nas últimas cinco safras? contratos

24. Qual a origem da prestadora de serviços de mecanização agrícola mais próxima? (se tiver mais que uma propriedade, responder pela principal)

( ) no Município de minha propriedade

( ) no Estado de minha propriedade

( ) fora do Estado de minha propriedade

( ) Não tenho conhecimento

25. Qual a distância em quilômetros do prestador de serviço de mecanização agrícola mais próximo? (Caso não tenha conhecimento, responda ZERO) KM 
26. Avalie a importância dos itens abaixo para CONTRATAÇÃo de mecanização (responder todas as alternativas, caso não contrate, marque as intenções para uma futura contratação)

Atribua notas de 5 a 1; sendo (5) muito importante e (1) sem importância

( ) Serviço mais ágil

( ) Reduz de custos

( ) Evita imobilizar capital em equipamentos

( ) Melhor qualidade do serviço contratado

( ) Dificuldade de contratação de mão de obra própria

( ) Fiscalização do Ministério Público na terceirização de maquinários

( ) Outro, Qual:

27. Quantos trabalhadores atuam em sua propriedade? fixos contratados em período de pico produtivo (temporários) total

28. Já teve problemas legais na contratação de serviços de mecanização agrícolas na sua região? ( ) Sim （ ) Não

Se SIM, qual a causa?

29. Já teve problemas com legislação trabalhista?

( ) Sim ( ) Não

Se sim, qual a principal causa?

30. Contrata serviços de pós-colheita de algum produtor?（） Sim （ ） Não

C) ASPECTOS COMERCIAIS

31. Qual o produto que você comercializa? (\% da produção total de café da fazenda):

$\%(\quad$ ) Café seco natural

$\%$ ( ) Café despolpado

$\%$ ( ) Café descascado

$\%$ ( ) Café processado - torrado.

$\%$ ( ) Outro, qual:

32. Qual o tipo de café que você comercializa? (\% da produção total de café da fazenda), (última safra):

$\%$ ( ) Café Tradicional (commodity)

$\%$ ( ) Café Gourmet

$\%$ ( ) Café Fairtrade

$\%$ ( ) Café Rainforest

$\%$ ( ) Café Ôrganico

$\%$ ( ) Café UTZ

$\%$ ( ) Outro, qual: 
33. 0 seu café é vendido com certificação de origem do Cerrado Mineiro?

( ) Sim ( ) Não ( ) Não sou do Cerrado Mineiro

Há quantos anos consecutivos possui este selo? anos

34. Como foi formalizado o documento de venda do seu café na última safra? (marcar a modalidade predominante, caso tenha ocorrido variações)

( ) Contrato escrito e registrado

( ) Contrato escrito, mas sem registro

( ) Apenas nota fiscal de entrega

( ) Sem documento, apenas acordo verbal

35. Em termos de preço e em sua opinião quais foram:

0 valor médio de mercado de uma saca de café na última safra? $\mathrm{R} \$$ reais

0 valor da SUA saca mais cara de café vendida na última safra? R\$ reais

36. Qual o percentual do total dessa sua produção que recebeu um preço maior do que o preço médio de mercado por safra? $\%$

37. Utiliza fontes de financiamento de terceiros para a atividade cafeeira?

( ) $\operatorname{Sim}$ ( ) Não

Se sim, de quem e qual o montante? (marcar todas as alternativas que ocorreram)

( ) Crédito rural público, com o valor de: $\mathrm{R} \$$ reais

( ) Empréstimo com comprador de café, com o valor de: $\mathrm{R} \$$ reais

38. Quantos dias em média de negociação até o recebimento do pagamento do seu café? dias

39. Qual o custo médio para venda do café em cada negociação (exemplo: gasto com advogado, reanálise em laboratórios privados da qualidade para confirmação do preço firmado, etc)? R\$ reais

40. Relacione as indústrias que o Sr. Costuma vender seu café com o percentual do total de sua produção de café (\%) o tempo de relacionamento com essa empresa (anos), a distância de sua propriedade principal (quilometros - KM) e a qualidade predominante do produto vendido para este comprador.

Indústria 1:

$\%$

Indústria 2: anos; KM; ( ) Alta; ( )Média; ( ) Baixa

Indústria 3: anos; KM; ( ) Alta; ( )Média; ( ) Baixa

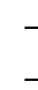
$\%$ anos; KM; ( ) Alta; ( )Média;

( ) Baixa

41. Você possui os seguintes sistemas em sua propriedade?:
Lavadores:
( ) Sim
( ) Não
Separadores de verdes:
( ) Sim
( ) Não
Secadores:
( ) $\mathrm{Sim}$
( ) Não 
Medidor de umidade:

( ) Sim ( ) Não

Sistema de armazenamento próprio:

Máquinas de despolpamento:

( ) $\operatorname{Sim}$ ( ) Não

Máquinas de descascamento:

( ) $\operatorname{Sim}$

( ) Não

( ) Sim ( ) Não

42. Qual o tipo de terreiro que você utiliza:
( ) Atijolado
( ) Asfaltado
( ) Cimentado
( ) Terra batida
( ) Suspenso
( ) Outro:

43. Como você faz a retirada do excesso de água após a lavagem:

( ) Não faço a lavagem

( ) Carrinho arredondado com furos

( ) Sistema bica de jogo

( ) Peneira com furos alongados

( ) Outro, qual:

44. Qual o percentual de cafés verdes que você inicia sua colheita? (caso não faça a análise e amostragem, escreva zero). $\%$.

45. Quantas operações de venda da safra de seu café você realiza ao longo de um ano? operações/ano.

46. Em quantos dias você vende toda a safra de seu café especial? (considere o tempo de entrega) dias

47. Qual o período necessário para vender toda a safra de café? dias

48. Qual o grau de incerteza e imprevisibilidade para as situações abaixo (responder todas as alternativas): Atribua notas de 5 a 1; sendo (5) Impossível prever e (1) Fácil prever.

a) Acertar, de modo aproximado, o valor da saca de café no mercado para a próxima safra:

b) Surgimento de novos indicadores/parâmetros (ex. cor, sabor, peneira, etc.) de qualidade pelas indústrias que compram seu café:

c) Surgimento de novas tecnologias que possam afetar diretamente a qualidade do café produzido em sua propriedade:

d) Mudanças de medidas fitossanitárias em legislação sobre defensivos: 
49. Qual a importância dos motivos abaixo para a escolha da comercialização do café com determinada indústria (responder todas as alternativas):

Atribua notas de 5 a 1; sendo (5) alta e (1) baixa

( ) Preço pago pelo café

( ) Antecipação de pagamento

( ) Relacionamento de longo prazo

( ) Reputação da empresa

( ) Reconhecimento de ser um cafeicultor de qualidade por ser fornecedor desse comprador

( ) Oferecimento de assistência técnica

( ) Oferecimento de serviço de armazenagem

Obrigado pelas suas respostas.

Horário Final: __hr__min 
APÊNDICE 2 - Descrição das variáveis da pesquisa

\begin{tabular}{|c|c|c|}
\hline Variável & Descrição & $\begin{array}{l}\text { Tipo de } \\
\text { variável }\end{array}$ \\
\hline Escolaridade & Escolaridade $\left(\geq 3^{\circ}\right.$ grau $\left.=1\right)$ & Dummy \\
\hline hectares & Número de hectares de plantação de café & Discreta \\
\hline mao_obra & $\begin{array}{l}\text { Escala de tipo de mão de obra na propriedade } \\
(1=\text { mecanizada, } 2=\text { semimecanizada, } \\
3=\text { manual })\end{array}$ & Ordinal \\
\hline perc_gourmet & $\begin{array}{l}\text { Percentual de produção de cafés gourmet em } \\
\text { relação a produção total }\end{array}$ & Contínua \\
\hline trein_cond & $\begin{array}{l}\text { Escala crescente de importância de treinamento } \\
\text { para condução da colheitadeira ( } 05 \text { pontos) }\end{array}$ & Ordinal \\
\hline exp_moto & $\begin{array}{l}\text { Anos de experiência necessários para condução } \\
\text { da colheitadeira }\end{array}$ & Discreta \\
\hline exist_prest & $\begin{array}{l}\text { Existência de prestador de serviço de } \\
\text { mecanização agrícola na região do produtor } \\
(\mathrm{Sim}=1)\end{array}$ & Dummy \\
\hline dist_prest & $\begin{array}{l}\text { Distância do prestador de serviço de } \\
\text { mecanização agrícola mais próximo do } \\
\text { produtor (em quilômetros) }\end{array}$ & Contínua \\
\hline log_val_maqprop & $\begin{array}{l}\text { Logaritmo natural do valor investidos em } \\
\text { maquinários específicos para a cafeicultura (em } \\
\text { reais) }\end{array}$ & Contínua \\
\hline atra_colheita & $\begin{array}{l}\text { Escala crescente de perda de valor devido a } \\
\text { atrasos na colheita ( } 05 \text { pontos) }\end{array}$ & Ordinal \\
\hline exist_tac & $\begin{array}{l}\text { Existência de termos de ajustamento de } \\
\text { conduta na região da propriedade }(\mathrm{Sim}=1)\end{array}$ & Dummy \\
\hline prob_trab & $\begin{array}{l}\text { Ocorrência de problema judicial trabalhista na } \\
\text { propriedade }(\operatorname{Sim}=1)\end{array}$ & Dummy \\
\hline out_cont & $\begin{array}{l}\text { Uso de contratos para outros tipos de serviço na } \\
\text { cafeicultura }(\mathrm{Sim}=1)\end{array}$ & Dummy \\
\hline tradicao_fam & $\begin{array}{l}\text { Tradição da família na cafeicultura }(\geq \text { terceira } \\
\text { geração=1) }\end{array}$ & Dummy \\
\hline temp_cafe & Tempo do produtor na cafeicultura (em anos) & Contínua \\
\hline
\end{tabular}


APÊNDICE 3 - Saídas do modelo econométrico pelo stata

\begin{tabular}{|c|c|c|c|c|c|c|c|}
\hline \multirow{2}{*}{ cont_mec } & \multicolumn{7}{|c|}{ cont_mec escola re hectares mao_obra perc_g t trei_c d exp_moto } \\
\hline & 1.0000 & & & & & & \\
\hline \multirow[t]{2}{*}{ escolaridade } & 0.2654 & 1.0000 & & & & & \\
\hline & 0.0062 & & & & & & \\
\hline \multirow[t]{2}{*}{ hectares } & -0.0906 & 0.2608 & 1.0000 & & & & \\
\hline & 0.3582 & 0.0072 & & & & & \\
\hline \multirow[t]{2}{*}{ mao_obra } & -0.4505 & -0.2097 & -0.2967 & 1.0000 & & & \\
\hline & 0.0000 & 0.0318 & 0.0021 & & & & \\
\hline \multirow[t]{2}{*}{ perc_gourmet } & -0.0130 & 0.3446 & 0.2409 & -0.1035 & 1.0000 & & \\
\hline & 0.8955 & 0.0003 & 0.0138 & 0.2959 & & & \\
\hline \multirow[t]{2}{*}{ trei_cond } & -0.0141 & 0.0028 & 0.0228 & 0.0844 & 0.0034 & 1.0000 & \\
\hline & 0.8867 & 0.9774 & 0.8176 & 0.3919 & 0.9728 & & \\
\hline \multirow[t]{2}{*}{ exp_moto } & -0.4329 & -0.1610 & 0.1291 & 0.1520 & -0.0419 & 0.0909 & 1.0000 \\
\hline & 0.0000 & 0.1010 & 0.1895 & 0.1218 & 0.6726 & 0.3562 & \\
\hline \multirow[t]{2}{*}{ exist_prest } & 0.0435 & 0.1097 & 0.1073 & -0.1511 & 0.1080 & 0.1397 & 0.1414 \\
\hline & 0.6593 & 0.2652 & 0.2761 & 0.1238 & 0.2753 & 0.1553 & 0.1502 \\
\hline \multirow[t]{2}{*}{ dist_prest } & -0.0720 & 0.2986 & 0.1236 & 0.1365 & 0.2665 & 0.1190 & -0.0532 \\
\hline & 0.4676 & 0.0021 & 0.2111 & 0.1671 & 0.0065 & 0.2288 & 0.5916 \\
\hline
\end{tabular}




\begin{tabular}{|c|c|c|c|c|c|c|c|}
\hline \multirow[t]{2}{*}{ log_val_ma p } & 0.4104 & 0.3615 & 0.3449 & -0.6956 & 0.2344 & -0.0387 & -0.1105 \\
\hline & 0.0000 & 0.0002 & 0.0003 & 0.0000 & 0.0166 & 0.6953 & 0.2618 \\
\hline \multirow[t]{2}{*}{ atra_colhe a } & -0.1246 & -0.0564 & -0.0327 & 0.0469 & 0.0802 & 0.0787 & 0.1214 \\
\hline & 0.2052 & 0.5674 & 0.7409 & 0.6344 & 0.4181 & 0.4250 & 0.2173 \\
\hline \multirow[t]{2}{*}{ exist_tac } & 0.0490 & 0.1319 & -0.0291 & -0.2205 & -0.0199 & 0.0382 & -0.0844 \\
\hline & 0.6213 & 0.1821 & 0.7693 & 0.0245 & 0.8422 & 0.6999 & 0.3942 \\
\hline \multirow[t]{2}{*}{ prob_trab } & 0.0585 & 0.2970 & 0.3316 & -0.1584 & 0.0923 & 0.1109 & 0.0811 \\
\hline & 0.5569 & 0.0023 & 0.0006 & 0.1100 & 0.3536 & 0.2649 & 0.4154 \\
\hline \multirow[t]{2}{*}{ out_cont } & -0.0488 & -0.3334 & -0.2284 & 0.3020 & -0.1823 & -0.0742 & 0.0447 \\
\hline & 0.6227 & 0.0005 & 0.0197 & 0.0018 & 0.0641 & 0.4541 & 0.6525 \\
\hline \multirow[t]{2}{*}{ tradicao_fam } & -0.1479 & 0.1404 & -0.0373 & 0.0748 & -0.0104 & -0.0999 & -0.0013 \\
\hline & 0.1321 & 0.1530 & 0.7055 & 0.4484 & 0.9164 & 0.3104 & 0.9896 \\
\hline \multirow[t]{3}{*}{ temp_cafe } & -0.1497 & -0.1467 & -0.0071 & 0.0292 & -0.0310 & -0.0162 & 0.1069 \\
\hline & 0.1275 & 0.1353 & 0.9428 & 0.7677 & 0.7548 & 0.8696 & 0.2779 \\
\hline & exist_ $t$ & dist_p t & $\log _{\text {va }} \sim p$ & atra_c a & exist_ c & rob_t $\sim b$ & out_cont \\
\hline exist_prest & 1.0000 & & & & & & \\
\hline \multirow[t]{2}{*}{ dist_prest } & -0.0590 & 1.0000 & & & & & \\
\hline & 0.5521 & & & & & & \\
\hline \multirow[t]{2}{*}{ log_val_ma p } & 0.2537 & 0.0348 & 1.0000 & & & & \\
\hline & 0.0090 & 0.7255 & & & & & \\
\hline
\end{tabular}




\begin{tabular}{|c|c|c|c|c|c|c|c|}
\hline \multirow[t]{2}{*}{ atra_colhe a } & 0.1176 & 0.1624 & 0.0706 & 1.0000 & & & \\
\hline & 0.2321 & 0.0995 & 0.4741 & & & & \\
\hline \multirow[t]{2}{*}{ exist_tac } & 0.0623 & -0.0564 & 0.1537 & -0.0128 & 1.0000 & & \\
\hline & 0.5300 & 0.5715 & 0.1193 & 0.8977 & & & \\
\hline \multirow[t]{2}{*}{ prob_trab } & 0.0999 & -0.0425 & 0.3138 & 0.0075 & 0.2095 & 1.0000 & \\
\hline & 0.3154 & 0.6718 & 0.0012 & 0.9401 & 0.0346 & & \\
\hline \multirow[t]{2}{*}{ out_cont } & 0.1616 & -0.1167 & -0.3006 & 0.0424 & -0.1587 & -0.2237 & 1.0000 \\
\hline & 0.1011 & 0.2406 & 0.0019 & 0.6689 & 0.1093 & 0.0231 & \\
\hline \multirow[t]{2}{*}{ tradicao_fam } & -0.0267 & -0.0696 & 0.0656 & 0.0242 & 0.1249 & 0.0720 & 0.0346 \\
\hline & 0.7865 & 0.4825 & 0.5060 & 0.8065 & 0.2065 & 0.4697 & 0.7271 \\
\hline \multirow[t]{3}{*}{ temp_cafe } & 0.0306 & 0.0528 & 0.0007 & 0.1390 & 0.0094 & -0.0304 & 0.1232 \\
\hline & 0.7566 & 0.5946 & 0.9946 & 0.1572 & 0.9243 & 0.7606 & 0.2128 \\
\hline & tradic $\sim$ m & temp_c e & & & & & \\
\hline tradicao_fam & 1.0000 & & & & & & \\
\hline \multirow[t]{2}{*}{ temp_cafe } & 0.2150 & 1.0000 & & & & & \\
\hline & 0.0276 & & & & & & \\
\hline
\end{tabular}

Probit regression

Log pseudolikelihood $=-51.525911$

\begin{tabular}{|c|c|c|c|c|c|c|}
\hline \multirow[b]{2}{*}{ cont_mec } & \multicolumn{3}{|c|}{ Robust } & \multirow[b]{2}{*}{$\mathrm{P}>|\mathbf{z}|$} & \multirow[b]{2}{*}{ [95\& Conf. } & \multirow[b]{2}{*}{ Interval] } \\
\hline & Coef. & Std. Brr. & $\mathrm{z}$ & & & \\
\hline escolaridade & .860158 & .3269167 & 2.63 & 0.009 & .219413 & 1.500903 \\
\hline hectares & -.0031283 & .0011108 & -2.82 & 0.005 & -.0053054 & -.0009512 \\
\hline mao_obra & -.9530112 & .1822731 & -5.23 & 0.000 & -1.31026 & -.5957625 \\
\hline perc_gourmet & -.4115334 & .6120936 & -0.67 & 0.501 & -1.611215 & .788148 \\
\hline _cons & 1.3736 & .3936778 & 3.49 & 0.000 & .6020056 & 2.145194 \\
\hline
\end{tabular}


Probit regression

Log pseudolikelihood $=-36.037203$
Number of obs

Wald chi2 (10)

Prob $>$ chi2 =

Pseudo R2 =
$=103$

32.13

0.0004

$=0.4894$

\begin{tabular}{r|rrrrrr}
\hline & \multicolumn{7}{|c}{$\begin{array}{c}\text { Robust } \\
\text { cont_mec }\end{array}$} & Coef. & St. Err. & $\mathrm{z}$ & $\mathrm{p}>|\mathrm{z}|$ & [958 Conf. Interval] \\
\hline escolaridade & .7697873 & .4295236 & 1.79 & 0.073 & -.0720635 & 1.611638 \\
hectares & -.004091 & .0012699 & -3.22 & 0.001 & -.00658 & -.0016021 \\
mao_obra & -.7929665 & .284833 & -2.78 & 0.005 & -1.351229 & -.2347041 \\
perc_gourmet & -.4259199 & .69683 & -0.61 & 0.541 & -1.791682 & .9398418 \\
trei_cond & .2817679 & .2893532 & 0.97 & 0.330 & -.2853541 & .8488898 \\
exp_moto & -.5674558 & .1508671 & -3.76 & 0.000 & -.8631499 & -.2717618 \\
exist_prest & -.1422537 & .3737092 & -0.38 & 0.703 & -.8747102 & .5902029 \\
dist_prest & -.0004335 & .0013595 & -0.32 & 0.750 & -.0030981 & .0022311 \\
log_val_maqprop & .2105818 & .0766268 & 2.75 & 0.006 & .0603961 & .3607675 \\
atra_colheita & -.2463278 & .1434641 & -1.72 & 0.086 & -.5275123 & .0348567 \\
_cons & -.0722283 & 1.578245 & -0.05 & 0.963 & -3.165533 & 3.021076 \\
\hline
\end{tabular}

Probit regression

Log pseudolikelihood $=-32.27187$

$\begin{array}{llr}\text { Number of obs } & = & 101 \\ \text { Wald chi2(13) } & = & 37.04 \\ \text { Prob > chi2 } & = & 0.0004 \\ \text { Pseudo R2 } & = & 0.5350\end{array}$

Robust

Std. Err. $\quad z \quad P>|z| \quad$ [958 Conf. Interval]

$\begin{array}{lllll}4500213 & 3.02 & 0.002 & .4789867 & 2.243038\end{array}$

.001371

$\begin{array}{ll}-3.64 & 0.000\end{array}$

$-.0076768$

$-.0023027$

$\begin{array}{lll}.3405358 & -3.02 & 0.003\end{array}$

$-1.696688$

$-.3618126$

.7104125

$-0.84 \quad 0.401$

$-1.989514$

.7952514

$1.42 \quad 0.155$

$-.1726081$

1.08604

1761673

$\begin{array}{ll}-3.69 & 0.000\end{array}$

$-.9954709$

$-.3049079$

$-.3218772$

.472818

$-0.68$

0.496

$-1.248583$

604829

.0016648

$\begin{array}{lll}-0.21 & 0.832\end{array}$

$-.0036152$

.0029105

.2589756

3.23

.1019991

.4159521

.1611737

0.001

$-.6399358$

$-.0081466$

- 9307705

$-2.01$

0.044

$-1.74777$

$-.1137711$

prob trab

out_cont

$-.1685882$

.4168441

$-2.23$

0.026

$-1.501544$

1. 164368

.55626

1.31

0.191

$-.3626613$

1. 817838

$-0.36$

0.719

$-3.830318$

2. 641483 


\begin{tabular}{r|rrrrrr}
\hline & \multicolumn{7}{|c}{$\begin{array}{c}\text { Robust } \\
\text { cont_mec }\end{array}$} & Coef. & Std. Err. & $\mathrm{z}$ & $\mathrm{P}>|\mathrm{z}|$ & [958 Conf. Interval] \\
\hline escolaridade & 1.877423 & .5295506 & 3.55 & 0.000 & .8395229 & 2.915323 \\
hectares & -.0053918 & .0014967 & -3.60 & 0.000 & -.0083253 & -.0024583 \\
mao_obra & -1.151986 & .4311868 & -2.67 & 0.008 & -1.997097 & -.3068753 \\
perc_gourmet & -1.279375 & .7389933 & -1.73 & 0.083 & -2.727776 & .1690248 \\
trei_cond & .3787929 & .3222173 & 1.18 & 0.240 & -.2527415 & 1.010327 \\
exp_moto & -.8187704 & .2530336 & -3.24 & 0.001 & -1.314707 & -.3228336 \\
exist_prest & -.3534104 & .5463152 & -0.65 & 0.518 & -1.424169 & .7173477 \\
dist_prest & -.001436 & .0020574 & -0.70 & 0.485 & -.0054683 & .0025963 \\
log_val_maqprop & .3351083 & .0914593 & 3.66 & 0.000 & .1558513 & .5143652 \\
atra_colheita & -.3083747 & .1867566 & -1.65 & 0.099 & -.6744109 & .0576616 \\
exist_tac & -1.330273 & .4977225 & -2.67 & 0.008 & -2.305791 & -.3547544 \\
prob_trab & .5978889 & .82946 & 0.72 & 0.471 & -1.027823 & 2.223601 \\
out_cont & 1.057064 & .6202775 & 1.70 & 0.088 & -.1586574 & 2.272786 \\
tradicao_fam & -1.576367 & .4934657 & -3.19 & 0.001 & -2.543542 & -.6091921 \\
temp_cafe & -.0157878 & .0184781 & -0.85 & 0.393 & -.0520043 & .0204286 \\
_cons & .1785578 & 1.713184 & 0.10 & 0.917 & -3.179222 & 3.536337 \\
\hline
\end{tabular}

Breusch-Pagan / Cook-Weisberg test for heteroskedasticity Ho: Constant variance

Variables: fitted values of cont_mec

$\begin{array}{llr}\operatorname{chi2}(1) & = & 1.49 \\ \text { Prob }>\text { chi2 } & = & 0.2216\end{array}$

\begin{tabular}{r|rr} 
Variable & VIF & $1 / \mathrm{VIF}$ \\
\hline log_val_ma p & 2.57 & 0.388683 \\
mao_obra & 2.39 & 0.419119 \\
escolaridade & 1.62 & 0.615830 \\
out_cont & 1.43 & 0.697166 \\
hectares & 1.40 & 0.716585 \\
prob_trab & 1.37 & 0.731021 \\
dist_prest & 1.34 & 0.748881 \\
exist_prest & 1.31 & 0.761720 \\
perc_gourmet & 1.25 & 0.797198 \\
exp_moto & 1.21 & 0.823822 \\
exist_tac & 1.18 & 0.845048 \\
tradicao_fam & 1.17 & 0.857088 \\
temp_cafe & 1.13 & 0.885361 \\
atra_colhe a & 1.12 & 0.891827 \\
trei_cond & 1.09 & 0.917069 \\
\hline Mean VIF & 1.44 &
\end{tabular}


Probit model for cont_mec

\begin{tabular}{c|rr|r}
\cline { 3 - 4 } Classified & D & $\sim \mathrm{D}$ & Total \\
\hline+ & 40 & 7 & 47 \\
- & 5 & 49 & 54 \\
\hline Total & 45 & 56 & 101
\end{tabular}

Classified + if predicted $\operatorname{Pr}(D)>=.5$

True $D$ defined as cont_mec $!=0$

\begin{tabular}{lll}
\hline Sensitivity & $\operatorname{Pr}(+\mid \mathrm{D})$ & 88.898 \\
Specificity & $\operatorname{Pr}(-\mid \sim \mathrm{D})$ & 87.508 \\
Positive predictive value & $\operatorname{Pr}(\mathrm{D} \mid+)$ & 85.118 \\
Negative predictive value & $\operatorname{Pr}(\sim \mathrm{D} \mid-)$ & 90.748 \\
\hline False + rate for true $\sim \mathrm{D}$ & $\operatorname{Pr}(+\mid \sim \mathrm{D})$ & 12.508 \\
False - rate for true D & $\operatorname{Pr}(-\mid \mathrm{D})$ & 11.118 \\
False + rate for classified + & $\operatorname{Pr}(\sim \mathrm{D} \mid+)$ & 14.898 \\
False - rate for classified - & $\operatorname{Pr}(\mathrm{D} \mid-)$ & 9.268 \\
\hline Correctly classified & & \\
\hline
\end{tabular}

